Danmarks Geologiske Undersøgelse.

II. Række. Nr. 72.

\title{
The Middle and Upper Cambrian Sedimentary Rocks of Bornholm
}

By

Kaj Hansen.

With 4 Plates.

I Kommission hos

C.A. Reitzels Forlag

Axel Sandal

København 1945. 
Danmarks Geologiske Undersøgelse.

II. Række. Nr. 72.

\section{The Middle and Upper Cambrian Sedimentary Rocks of Bornholm}

By

Kaj Hansen.

With 4 Plates.

I Kommission hos

C. A. Reitzels Forlag Axel Sandal

Kobenhavn 1945. 


\section{Contents.}

Preface

Page

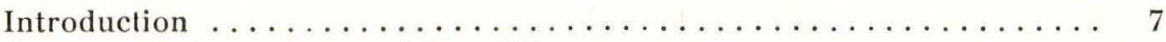

Chapter I. Description of Localities ................ 8

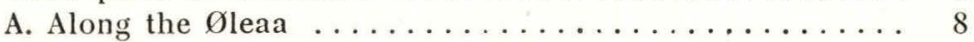

B. $\gg$, Læsaa ..................... 20

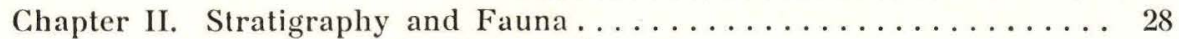

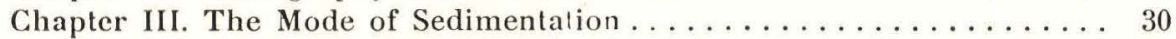

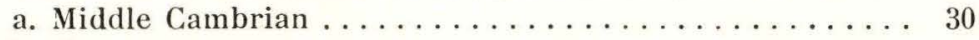

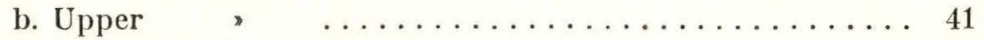

Chapter IV. Palaeogeography ..................... 51

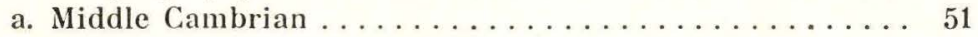

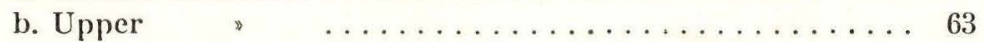

Chapter V. Tectonics ........................ 70

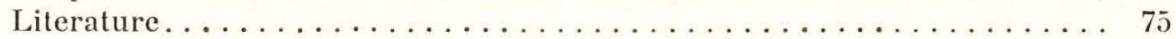




\section{Preface.}

This study of the Bornholm alum shales and their limestones was undertaken in the years 1936-1939, and the manuscript has lain in the finished state since then.

It is my pleasant duty to thank Denmark's Geological Survey for accepling this paper in its publications; I would also thank the Rask-Ørsted Fund for the necessary grant of the cost of translation and the Carlsen-Lange Legacy for furnishing the means to enable me to make a study-journey to the Cambro-Silurian occurrences in Sweden.

November 1943.

KAJ HANSEN 


\section{Introduction.}

$\mathrm{T}$

he alum shales of Bornholm and their stinkstones were mentioned as long ago as by ØRSTED \& ESMARCK, though these authors occupied themselves chiefly with the question of their practical utility, their conclusion being that they are not so bituminous as to permit of their being used for fuel in the burning of lime, as for instance the shales of Västergötland are still used today. (ØRSTED \& ESMARCK 1819).

ForchHAmmer also refers to these alum shales and names a few fossils, but his description of "the transitional formation" includes the whole of the series that extends from Middle Cambrian to Upper Graptolith Shales inclusive (ForсhнаммеR 1835).

It is only with JoHnstrup that there begins a more comprehensive investigation of the fossiliferous Cambro-Silurian and an attempt at a more exact division of it on a palaeontological basis, on the lines of the stratigraphical surveys that were started at the same time in Scania (JoHNSTRUP 1891).

But we obtain no closer knowledge of the stratigraphy and fossil contents of this series until Grönwall and later Poulsen complete their investigations (Grönwall 1902, Poulsen 1923). Both authors, it is true, describe a number of characteristic features of the rocks, but hitherto there has been no systematic petrographical examination of them; and as the present investigation has been able to elucidate still more peculiarities in the development of the series, a more detailed description of the various localities will be necessary. 


\title{
Chapter I. \\ Description of Localities.
}

\section{A. The Series along the River Øleaa.}

\begin{abstract}
$\mathrm{A}^{1}$
t the river Øleaa the Middle and Upper Cambrian series are visible along the stretch between Borggaard and Bjergegaard (fig. 1), and it begins with the Exsulans Limestone.

Locality 1. The Exsulans Limestone overlying the Rispebjerg Sandstone is visible for the first time just east of Borggaard. The surface of the sandstone is considerably corroded and very uneven. In its lower part the Exsulans Limestone is dark green, and it contains numerous shell fragments, grains of glauconite and quartz as well as pebbles of black phosphoritic sandstone of the types found in Rispebjerg Sandstone. Finally, there are nodules of dense, brown phosphorite. They are often sharply angular and show but faint signs of wear and rounding.

The single quartz grains (Pl. 1, fig. 1) are of the same form and dimensions as those of Rispebjerg Sandstone. Larger or smaller fragments of brown phosphorite adhere to some of them.

Glauconite occurs in large quantities and always in the form of irregular nodules, almost all of which along the edge have a border of clear crystals of calcite which have penetrated more or less into the glauconite and replaced it in the same manner as HADDING describes from the Swedish glauconite deposits (HADDING 1932). There are representatives of all possible stages in this process, from large glauconite nodules with a narrow margin of calcite to phases in which almost all the glauconite has disappeared and been substituted by a group of clear calcite crystals.

The shell fragments are from both Trilobites and Brachiopods. The ground mass in this Exsulans Limestones consists of very fine calcareous mud.
\end{abstract}




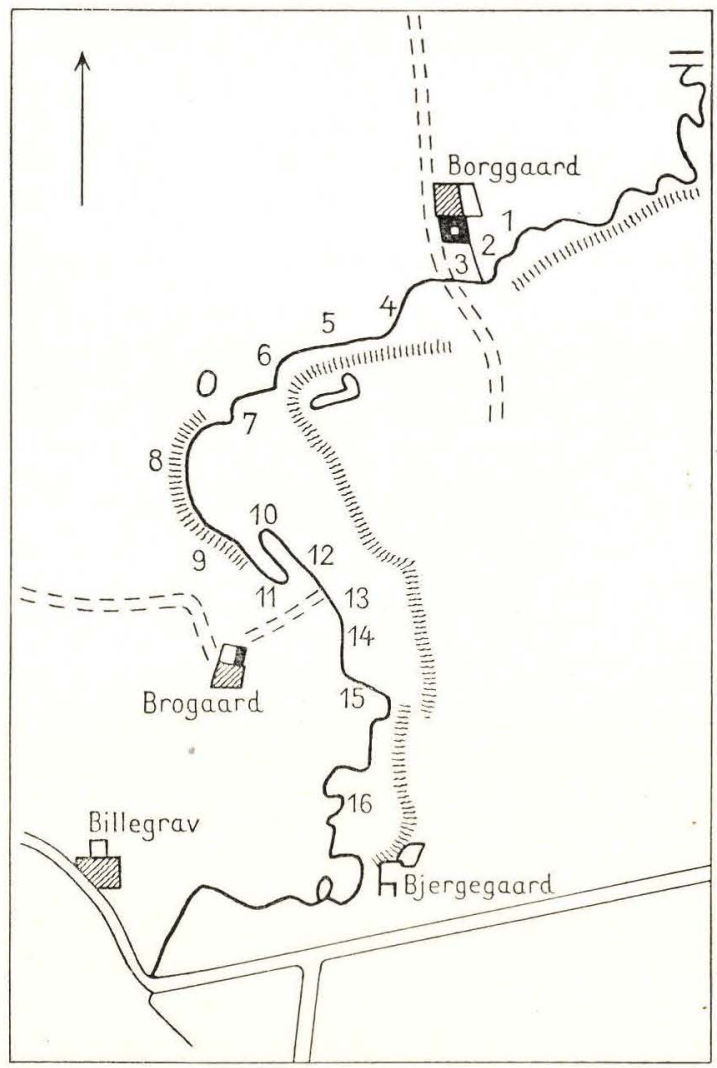

Fig. 1. Outcrops along the Øleaa.

Locality 2. Just below the dam that is built across the river the Exsulans Limestone again appears in the river bottom. Below it is greyish green and contains numerous grains of quartz, glauconite concretions and fragments of both chitinous and calcareous-shelled organisms, both Trilobites and Brachiopods. Small pieces of phosphorite nodules and pebbles of black, phosphatized Rispebjerg Sandstone also occur in this part of the limestone.

Upwards the number of quartz grains and glauconite concretions decreases, the greyish-green limestone being overlain by a light grey fragment-limestone, and the pebbles of phosphoritic sandstone also disappear.

The grey limestone consists of very fine, partly re-crystallized calcareous mud in which are many shell fragments, mainly of Trilobites, a few small quartz grains and small grains of glauconite, but they are much less frequent than in the greyish-green limestone. This grey limestone has a thickness of $4 \mathrm{~cm}$. 
Over this fragment limestone there is a black stinkstone. The boundary between the two rocks is faintly undulating, but very sharp everywhere. At some places on the surface of the Exsulans Limestone there is a sandy stratum containing rolled grains of quartz, phosphorite and glauconite in a matrix of fine calcareous mud. At other places this sandy deposit is absent.

In several places the lower part of the stinkstone has a peculiar stemmy structure (figs. 2 and 3) with long slender vertical crystals of calcite having black feathery or fanshaped figures inside. Macroscopically the whole appearance recalls "cone-in-cone" structure. The length of these crystals varies very considerably and attains to $1.5 \mathrm{~cm}$. At little above the base of the stinkstone the structure changes in character. The crystals are no longer vertically arranged, they are shorter and more rounded in outline, and the entire picture assumes more the character of calcareous sand, of the same type as that shown in pl. I, fig. 3, in which the sand grains consist of rolled fragments of calcite crystals separated by a black organic or sulphidic mud.

On the stretch from the dam down to the channel carrying the water from the farm water-mill the river bottom consists of stinkstone in some places, in others of the greyish-green Exsulans Limestone. The surfaces of the latter are quite covered with pebbles of black phosphatized Rispebjerg Sandstone (fig. 4). Here the stinkstone forms a continuous layer, the surface of which is uneven and forms large, slightly domed calottes.

The next stretch of the river bottom is formed of Rispebjerg Sandstone (KaJ Hansen 1937 b).

Locality 3. Below the fence running west from the mill stream the alum shale is to be seen in the left bank. In the bottom of the river $5 \mathrm{~m}$ below the fence are two stinkstone calottes which are very hard and impervious to attempts to break them.

The alum shale is brownish-black with irregular stratification. In thin section it is seen to consist of very small, sub-angular quartz grains $0.015 \mathrm{~mm}$ in size, and numerous small mica lamellae, the whole in a matrix of fine argillaceous material and black organic and sulphidic mud. An analysis of the rock made in the laboratory of Denmark's Geological Survey gave the following result:

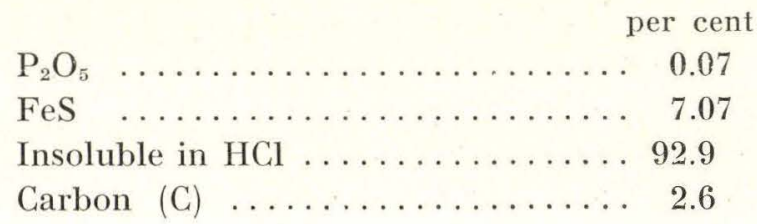


Fig. 2. The boundary between Exsulans Limestone and stinkstone in Loc. 2 at the Øleaa. Below, the Exsulans Limestone, of which the upper part con-

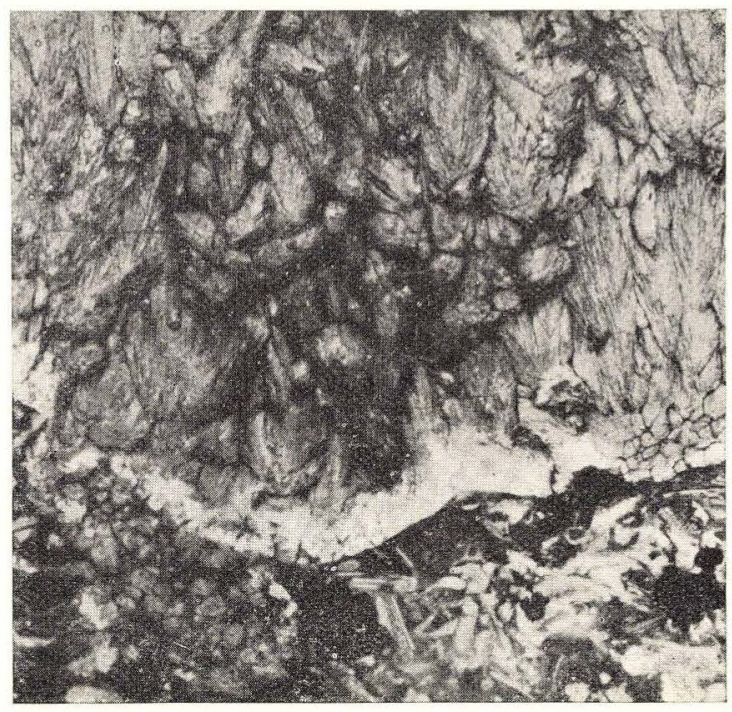
tains some glauconite, shell fragments and is also phosphatized somewhat. Overlying it is a thin band with clear, crystalline calcite, and uppermost the stinkstone with the long narrow calcite crystals of "cone-in-cone" structure with the feathery figures. $7 \times$. 1 nicol. Slide 839 .

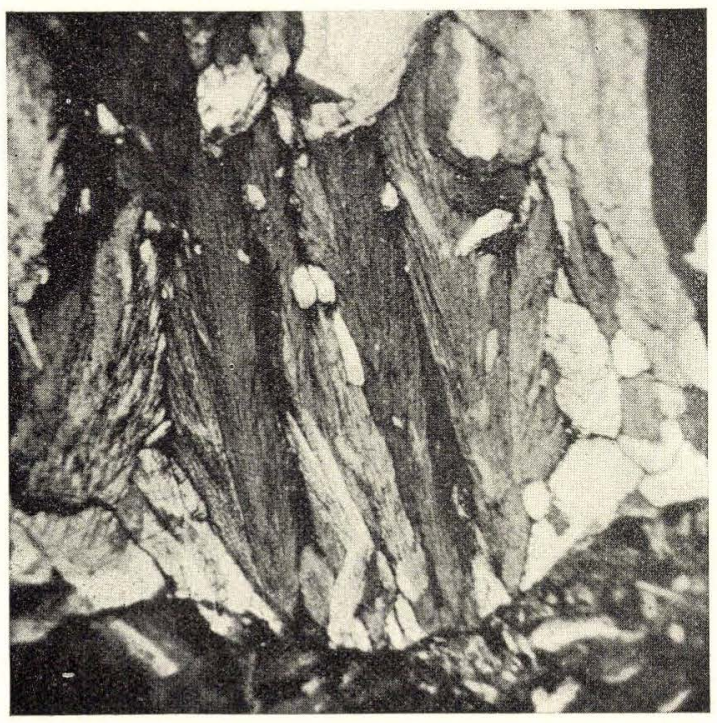

Fig. 3. Detail of fig. 2, showing more clearly that the "coneincone" structure is formed of long, narrow calcite crystals. $11 \times$. Nicols + . Slide 839 . 
This analysis shows that the greater part of the shale consists of quartz, mica and clayed material, and that ferrous sulphide dominates the organic mud.

Locality 4. On the northeast-southwest stretch of the river Rispebjerg Sandstone is to be seen farthest to the northeast (KAJ Hansen $1937 \mathrm{~b})$. Below this the river bottom consists of Exsulans Limestone with the overlying stinkstone exactly as in Localities 1 and 2 . The strata dip $4^{\circ}$ towards S $28^{\circ} \mathrm{E}$. Along the greater part of this stretch

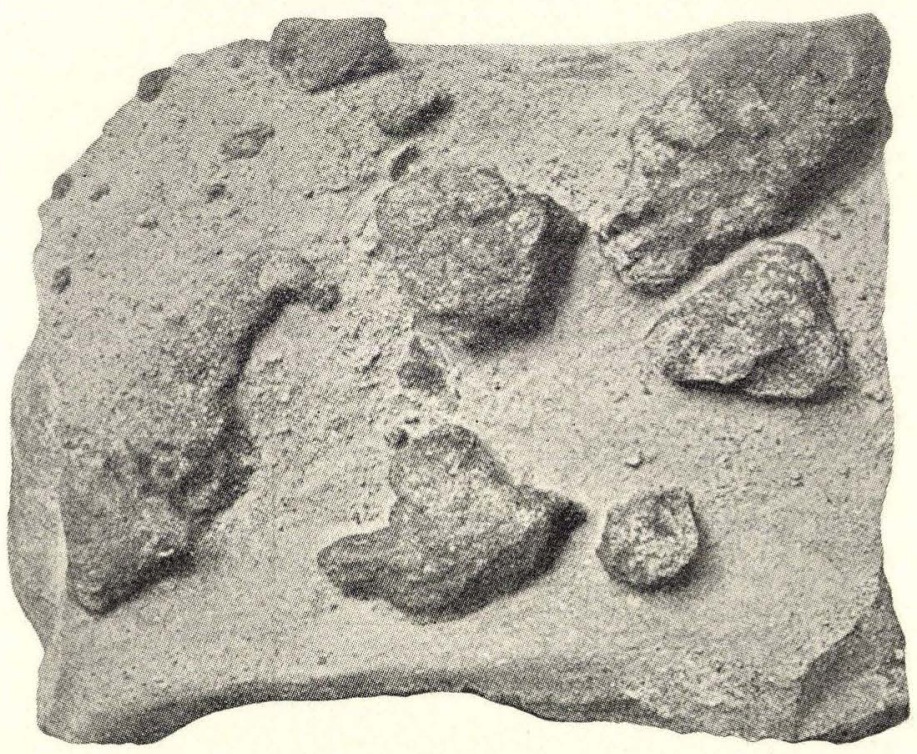

Fig. 4. Surface of the green Exsulans Limestone with phosphorite nodules. Øleaa, Loc. 2. (After GRönwall 1902).

the greyish-green limestone with phosphorite nodules is to be seen on the surface in the right bank, whereas the left bank consists of alum shale.

Here too the Exsulans Limestone consists of a greyish-green limestone at the bottom with the same development as described above. And again the surfaces of this limestone are studded with pebbles of black phosphatized Rispebjerg standstone.

The upper $4 \mathrm{~cm}$ of the Exsulans Limestone consists, as in Locality 2, of a pale grey fragment limestone with many fossils. The calcareous mud is more or less re-crystallized (pl. I, fig. 2). In most cases it forms a mosaic of fine crystals of sizes round about $0.02 \mathrm{~mm}$, but here and there one finds more coarse crystalline areas and veins. The limestone 
also contains a number of small angular quartz grains and small grains of glauconite.

The Exsulans Limestone is overlain by a black stinkstone with the same structure development as in Locality 2.

GröNWALL (1902) states that the Exsulans Limestone is overlain direct by stinkstone lying in calotte-shaped patches which are half stinkstone lenses placed close together, making it all look like a continuous bed of stinkstone. This is scarcely quite correct, however. As in Locality 2, the surface of the stinkstone forms large flat calottes, but so flat that they cannot be spoken of as half stinkstone lense. Here as in Locality 2 the stinkstone must be regarded as a continuous

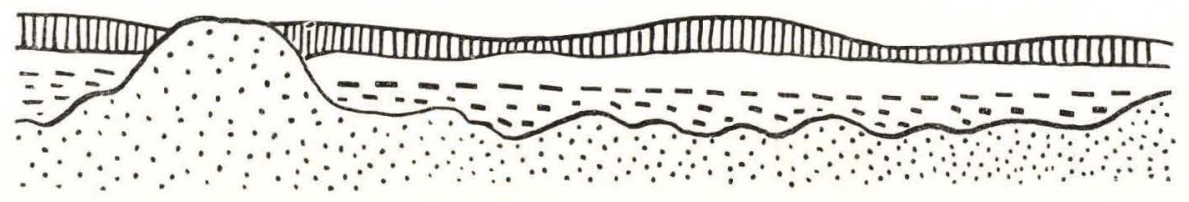

Fig. 5. Section through the Middle Cambrian at Loc 4 in the Oleaa. Below, Rispebjerg Sandstone (stippled). Over it Exsulans Limestone with phosphorite nodules in the lower part. Uppermost, stinkstone (vertically hatched) with slightly domed surface. The height of the entire section is about $70 \mathrm{~cm}$.

limestone bed with an uneven and domed surface (see fig. 5). Such is the sequence in broad outlines, but on going more into detail it will be found that there are several local deviations. At some places there are parts with steely grey Rispebjerg Sandstone, of which the surface reaches the same level as the surface of the stinkstone. This can scarcely be interpreted otherwise than as shown in fig. 5. The surface of the Rispebjerg Sandstone was so uneven that scattered small hummocks of it remained exposed during the deposition of both the Exsulans Limestone and the overlying stinkstone. It was only with the deposition of the alum shale over the latter that these sandstone hummocks were at last covered by a later sediment. But as the thickness of the Exsulans Limestone was estimated at $25 \mathrm{~cm}$ by GRöNwALL and the thickness of the overlying stinkstone is scarcely more than $15-20 \mathrm{~cm}$, it will be understood that the dimensions concerned are quite inconsiderable.

The stinkstone is overlain by alum shale, the thickness of which was estimated by Grönwall at $0.8 \mathrm{~m}$. No stinkstone lenses are observable in the shale, but, as Grönwall writes, it presents such undulations that one must presume that it does contain some. In the museum collections GröNwALL also found fragments of stinkstone 
lenses whose fossil content shows that they must be referred to this occurrence of alum shale.

Locality 5. In the old limestone quarry below the Ringborgen there is the following section (fig. 6).

Uppermost e. alum shale . .............

d. Andrarum Limestone ....... $55 \mathrm{~cm}$.

c. alum shale ............ $1 \mathrm{~cm}$.

b. black limestone bed ....... $20 \mathrm{~cm}$.

a. alum shale ..............

The lower alum shale (a) forms the bottom of the river and represents the same deposit that was found overlying the Exsulans Limestone and its stinkstone in Localities 3 and 4 .

The stinkstone bed (b) belongs to the zone containing Paradoxides davidis (GröNWALL 1902). Its structure varies somewhat from place to place. At some points the lowest part consists of a dense, dull, almost quite black limestone with few or several crystalline and lightercoloured areas, and elongated, horizontal, brassy-yellow areas of pyrites. In thin section this part of the limestone consists of re-crystallized calcareous mud of almost the same structure as that in the Exsulans Limestone. Various foreign bodies are present in this groundmass. (Pl. II, fig. 1). GRöNwall says that it contains phosphorite nodules, but fewer than in the corresponding horizon in the Læsaa. The structure of the nodules will appear from figures 1 and 3 on pl. II. As a rule they are quite black and opaque, and only in very thin sections is it possible to see that they are interspersed with veins of calcite (the white in the figures; see p. 22), but otherwise consist of a phosphorite, considerably debased by black sulphidic and organic mud. If a piece of the limestone is laid in diluted hydrochloric acid the lime dissolves and the phosphorites remain in the form of black concretions of a leathery and spongy consistence. Small rolled quartz grains occur in this part of the limestone bed either diffusely or crowded together in the Brachiopod shells (pl. II, fig. 2).

The limestone is also rich in shell fragments of both Trilobites and Brachiopods. The thickness of this part of the limestone bed varies somewhat from place to place, but in this locality nowhere exceeds $7 \mathrm{~cm}$. Overlying it is a black, glistening, crystalline limestone. The boundary between the two is very uneven and contains numerous sharp cavities. At one place the lower dull limestone is entirely missing, and the crystalline part of the limestone begins at the base with a thin belt with cone-in-cone structure. 
The upper and much the thickest part of the limestone in this section reveals a structure similar to that shown on pl. I, fig. 3. It is built up of grains of calcite, in rather differing shapes and sizes. Most frequently each grain consists of a single crystalline individual, but in a few

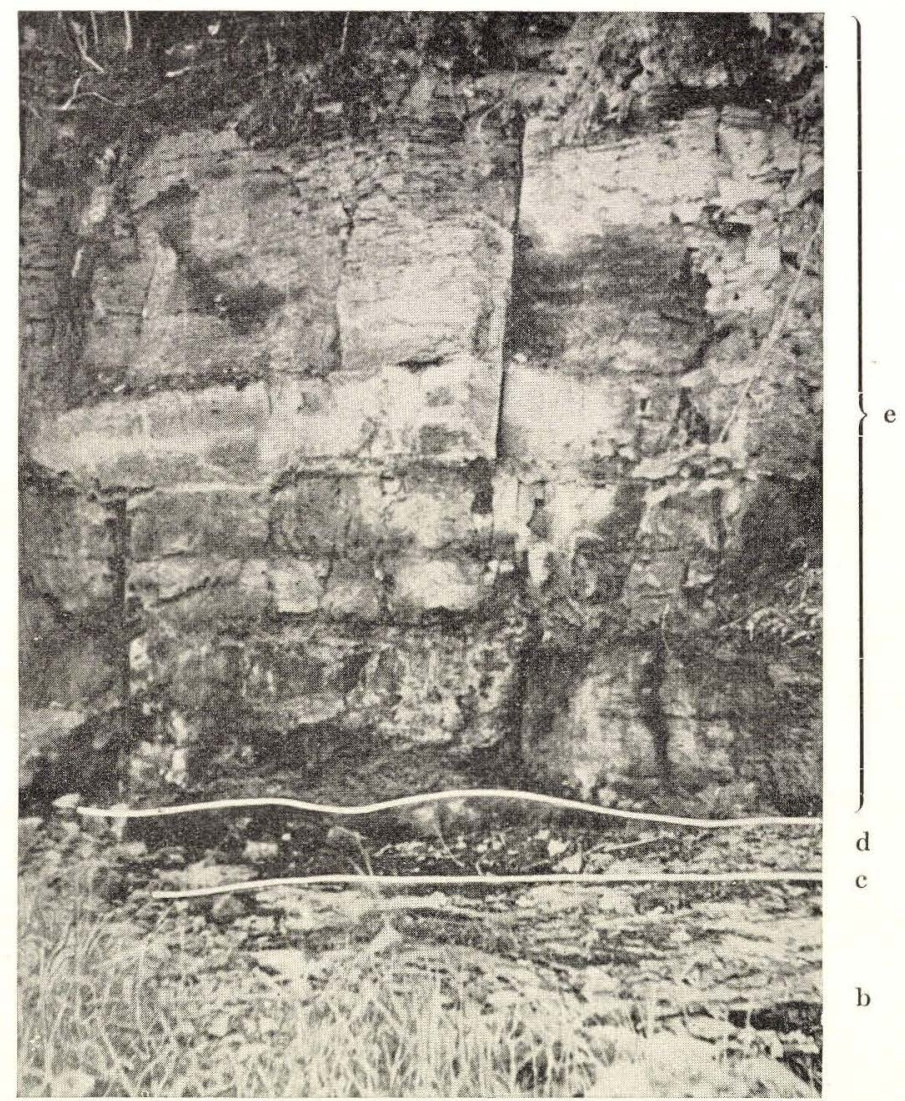

Fig. 6. The limestone quarry at the Øleaa, Loc. 5. The area between the two white lines is Andrarum Limestone.

cases they are composed of several cohering crystals. The grain size varies from 0.1 to $1 \mathrm{~mm}$. Almost all grains contain some fine black mud inside. At times this forms feathery figures like the "cone-in-cone" crystals in the stinkstone overlying the Exsulans Limestone. The margins of the grains are sharp in most cases. Often they lie close together, but in other cases they are separated by black opaque mud. Presumably this rock must be taken to be a lime-sand limestone, in which the sand grains consist of rolled crystals of calcite (see below, p. 38). 
The alum shale (c) is of a type similar to that in Locality 3, but somewhat finer in the grain.

The Andrarum Limestone is a dense or fine-grained, darker or lighter grey limestone, fairly homogeneous throughout its whole thickness. It consists of very fine, more or less re-crystallized calcareous mud with numerous shell fragments (pl. III, fig. 1). In some places it contains subordinate regions of more coarsely-crystalline limestone (pl. IV, fig. 2). In thin section it is found that these crystals have formed in association with shell fragments: along the sides of a shell fragment there has developed a row of closely placed palisade-formed calcite crystals, all with the same optical orientation and with their longitudinal axis at right angles to the surface of the shell. During the continuation of the crystallization process some of these crystals have grown more than others. As moreover the calcareous mud tends to crystallize as pure calcite, without foreign bodies, the black impurities in the calcareous mud are, gradually as crystallization advances, concentrated more and more in the interstices between the crystal individuals (KAISIN 1926) and furthermore have the effect that some of the latter are inhibited in their growth. As the crystals all have the same optical orientation, they will all eventually have the appearance of one large crystal pervaded by irregular, winding smears and with a flocculent outline. It is possible that later on there was some recrystallization. Besides shell fragments there are isolated grains of glauconite and quartz as well as a little pyrites. This development is also encountered in other stinkstones and can be followed step by step when the various thin sections are compared.

The uppermost alum shale (e) is hard and coal-black and cleaves into thin laminae. It is much finer in the grain than the alum shale (c) and that in Locality 3. The content of quartz grains is also much lower than in these shales, whereas the clayey, micaceous material and the black organic and sulphidic mud are more preponderant. GRöNWALL states that it contains lenses of coarsely crystalline stinkstone, and Thonsen (1931) confirms this. In 1937 and 1938 there were no stinkstone lenses to be seen, nor does Poulsen mention any; but at several places there are large lenticular cavities in the face of the shale, of the same shape and size as the stinkstone lenses elsewhere. At $2 \mathrm{~m}$ above the Andrarum Limestone Poulsen found a poorly preserved specimen of an Agnostus, possibly Agnostus pisiformis (POUlsen 1923).

Andrarum Limestone was formerly used in the manufacturing of cement. THorsen states that it contains so much clay that it was once 
cmployed for making Roman cement. An account of the local manufacturing of cement in former times is also given by Thorsen (1931).

Locality 6. From the quarry the river continues southwest along an almost straight line. Here in the river bed one sees first Rispebjerg Sandstone, then Exsulans Limestone, and finally the stinkstone overlying it. The river then bends sharply to the south and we now see in the right bank alum shale overlain by a limestone bed of the Davidis Zone with its phosphorite nodules. The section has a length of about 2 metres. Farthest south the thickness of the limestone is $35 \mathrm{~cm}$, but northwards it seems to thin off to nothing. The phosphorite nodules form an almost horizontal level, farthest south lying $22 \mathrm{~cm}$ above the base of the bed, but at the north end just over the base. The part of the limestone bed that lies below the phosphorite horizon consists of lime-sand limestone of a type similar to that referred to at the same level in Locality 5. The grain sizes are rather heterogeneous and seem to be largest in the lower part, though the explanation of this may be that recrystallization may have taken place there later. The phosphorite nodules lie in a rather fine-grained limestone. Above the nodules is a very fine-grained black limestone. It is almost impossible to decide whether this is a fine-grained lime-sand limestone or merely re-crystallized fine calcareous mud.

At the south end of this section the river turns sharply west again. In the left bank at the bend we see again the limestone bed of the Davidis Zone with its phosphorite nodules, and in the river bottom in front of it is alum shale with two stinkstone lenses below it. These lenses are so hard that it was impossible to break them. Here the phosphorite nodules lie lowest in the bed and are overlain by a grey, fossiliferous limestone which in turn is overlain by a thin bed of black finely crystalline limestone of the same type as that described above. The grey fragment-limestone consists of fine calcareous mud with numerous shell fragments and small phosphorites, some of them fragmentary.

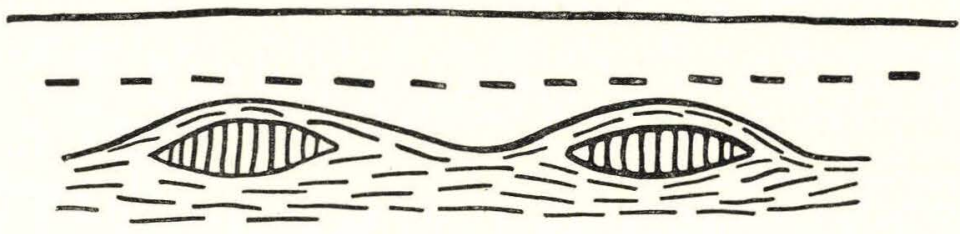

Fig. 7. Stratification in Loc. 6 at the Øleaa. Above, the limestone bed of the Davidis Zone with the phosphorite nodule horizon. Under this alum shale with stinkstone lenses. 
The apparently curious circumstance that in some places the phosphorite nodules lie just above the base of the limestone bed and in others higher up is explained by the fact that, as shown in fig. 7, the lower bedding plane of the limestone is not flat, but follows the domed surface of the underlying shale with its stinkstone lenses. The phosphorite nodules form an almost horizontal level, and where this level is above the lenses in the alum shale, where the limestone bed is thinnest, it lies just above the base of the bed, whereas above the intervals between the lenses, where the bed is thickest, it lies some distance up in the bed.

From here the river runs west again, and in the right bank the alum shale is to be seen lowest, overlain by the limestone bed of the Davidis Zone, easily recognizable by its phosphorites. The bed is then overlain by a thin deposit of alum shale and this again by Andrarum Limestone.

Locality 7. Right in the bend the bottom is formed of Andrarum Limestone, of which the surface is rather rich in pyritic segregations. A little farther down the river there is a little alum shale in the left bank. Just before the river turns south again there is a $1.20 \mathrm{~m}$ section of alum shale in the right bank. The strata dip $4^{\circ}$ towards $\mathrm{S} 70^{\circ} \mathrm{E}$. Here Poulsen found specimens of Agnostus pisiformis.

Locality 8. In the right bank of the river is a section in alum shale, about $50 \mathrm{~m}$ long and about $1.20 \mathrm{~m}$ high. At the south end are a few stinkstone lenses, and a little more to the north the shale lies in flat undulations, where presumably there are other stinkstone lenses. The shale contains Olenus (Poulsen 1923). The shale is coal black and hard and cleaves in fairly thick laminae with almost flat cleavage planes. Under the microscope it has almost the same composition as the alum shale uppermost in the section in Locality 5 . The bedding planes are often yellow with segregated sulphur. Of the anthraconite lenses only the upper part could be sampled. They consist of long stemmy crystals jumbled together, $2.5 \mathrm{~cm}$ long and about $0.4 \mathrm{~cm}$ thick and vertically arranged. In thin section the crystals contain black, narrow, forked or cup-shaped figures. The cross-section varies in the different crystals. Some are fairly regular, whereas others have narrow crests in their longitudinal direction. In thin section one sees numerous black thin winding smears with no regular concentric arrangement (pl. IV, fig. 1).

Just to the north (Poulsen loc. 13) is a pit in alum shale $4 \mathrm{~m}$ deep. Small Brachiopods are found in the lowest part, though infre- 
quently. About $2.4 \mathrm{~m}$ above the bottom of the pit are scattered specimens of Agnostus pisiformis. At $3.6 \mathrm{~m}$ up are large numbers of Brachiopods in a shale bed $0.5 \mathrm{~m}$ thick.

Locality 9. In the right bank of the river there is a section in alum shale, about $25 \mathrm{~m}$ long and about $3.70 \mathrm{~m}$ high, with stinkstone lenses at several levels. The shale is coal black and friable and cleaves into very thin laminae with flat, bright yellow cleavage planes. About $0.25 \mathrm{~m}$ above the river Poulsen found considerable quantities of Homagnostus obesus, and a little lower down the section a few small Brachiopods (Poulsen 1923). The stinkstone is coal black and rubs off readily. The lower and middle parts of the lenses are finely crystalline and thinly stratified, whereas in some of them the upper part is coarsely crystalline and stemmy, with the calcite crystals obliquely on the surface. Uppermost in the section are numerous stinkstone lenses of fist size. These are finely crystalline all through, with no sign of stemmy structure.

Locality 10. Right in the bend of the river there is shale with Homagnostus obesus in large quantities on the bedding planes. The shale is coal black and hard and cleaves with almost flat planes into laminae about $0.5 \mathrm{~cm}$. An analysis made at the laboratory of Denmark's Geological Survey gave the following composition:

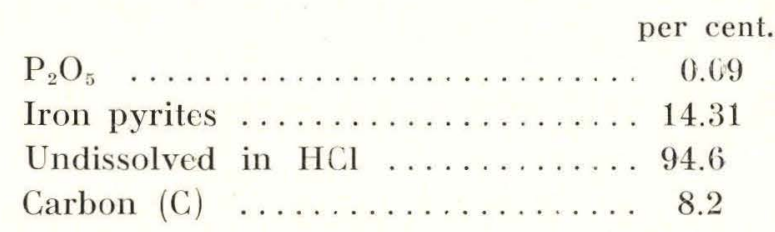

Locality 11. In the right bank is a low section, below with alum shale overlain by a bed of stinkstone $30 \mathrm{~cm}$ thick. In the structure of this bed strata with shells of Orusia lenticularis alternate with almost shell-free strata. The shelly strata are usually lighter in colour and consist of immense quantities of Orusia shells lying in finely crystallized calcareous mud, where the crystals form a normal crystal mosaic. Some of the shelly strata are double, in that the two parts are separated by a thin, darker band with fewer shells, along the surfaces of which is a row of small, long calcite crystals of the same shape and with the same black figures as those in the shell-free deposits, but smaller. The latter have a cone-in-cone structure as shown in pl. III, figs. 2 and 3, and consist of several layers of narrow, elongated crystals, inside which are black forked figures. These 
crystals are more developed in the outer zones of the limestone beds, whereas in their interior they become shorter and broader (pl. III, fig. 3); the length may reach $3 \mathrm{~cm}$. The limestone also contains numerous crystals of barite.

Locality 12. In the left bank is a little alum shale; no fossils have so far been found.

Locality 13. In the river bed is a low shale bed, in which Poulsen found Orusia lenticularis.

Locality 14. In the river bottom are two stinkstones lenses, one finely crystalline all through, the other having a marginal zone that is coarsely crystalline. In this Poulsen found a few fragments of Leptoplastus stenotus.

Locality 15. This is Jespersen and Johnstrup's old locality for Green Shales (KaJ Hansen 1936).

Locality 16. In the left bank of the river is a stinkstones lens and below it some alum shale lying almost horizontally. The limestone is deposited in thin beds, is coal black and rubs off readily. In thin section it is clearly stratified, entirely black areas of cryptocrystalline lime strongly mixed with black mud alternating with thin strata of more coarse crystalline lime. The coarser crystalline beds vary considerably in thickness, but the average is about $1 \mathrm{~mm}$. Sometimes they widen out to one side or the other. In thin section they mostly resemble the veins of calcite seen in other limestones, in which the calcite forms a crystal mosaic of relatively large crystals $(0.5 \mathrm{~mm})$. Here however the crystals are full of black mud, which forms quite a network in them.

The black parts also consist of calcite crystals, though these are much smaller than in the veins, and the content of black organic mud is much higher in these strata, which have an average thickness of $2-3 \mathrm{~mm}$.

\section{B. The Series along the River Lasaa.}

Locality I. (Fig. 8). The series along the Læsaa begins with a calcareous, highly arenaceous deposit which GrönwaLL calls grey clay, and over this lies a pyritic conglomerate. GrönwaLL considers the clay to be weathered Exsulans Limestone (GRönwall 1902). This assumption was later questioned (KAJ HANSEN 1937b', but it has since 


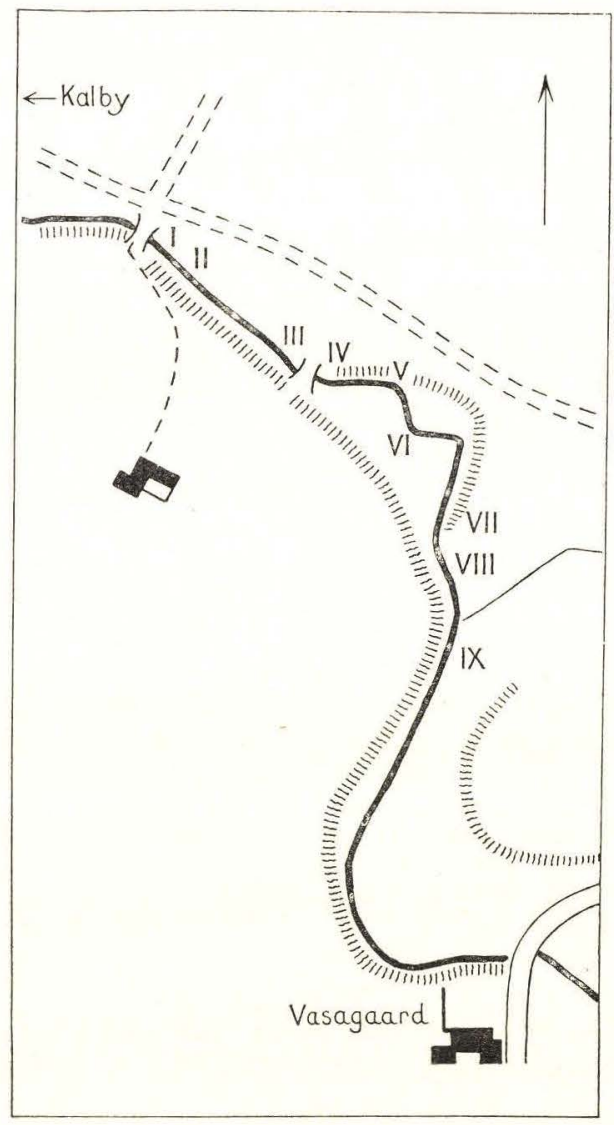

Fig. 8. Outcrops along the Læsaa.

proved to be correct (Poulsen 1942). Both the sandy deposit and the pyrites have already been described in detail (GRÖNwALL 1902, KaJ Hansen 1937). The pyritic conglomerate is overlain by alum shale of exactly the same type as that in Locality 3 at the Oleaa.

Locality II. The alum shale in Locality I continues in the right bank a few metres down the river and is then overlain by a bed of stinkstone that can be seen both in the right bank and for a distance out in the middle of the river bed (fig. 9). At the bottom this limestone bed consists of black crystalline limestone, this part of the limestone represents the Paradoxides davidis Zone and has a thickness of $25 \mathrm{~cm}$ (GRönwalL 1902). Here the zone has a development similar to that along the Øleaa (pl. I, fig. 3) and in this case too must be regarded as a lime-sand limestone. The size of the grains varies a little, as coarse and 
fine strata alternate. In the finer strata the majority of the grains have a size of about $0.1 \mathrm{~mm}$, but in the coarser ones it is $1 \mathrm{~mm}$. As at the Øleaa the zone contains a phosphorite conglomerate (fig. 10). Right in at the steep bank this lies lowest in the limestone bed, whereas out in the river it is much higher. The reason is (as at the Øleaa) that the thickness of the lime-sand limestone varies as a consequence of the

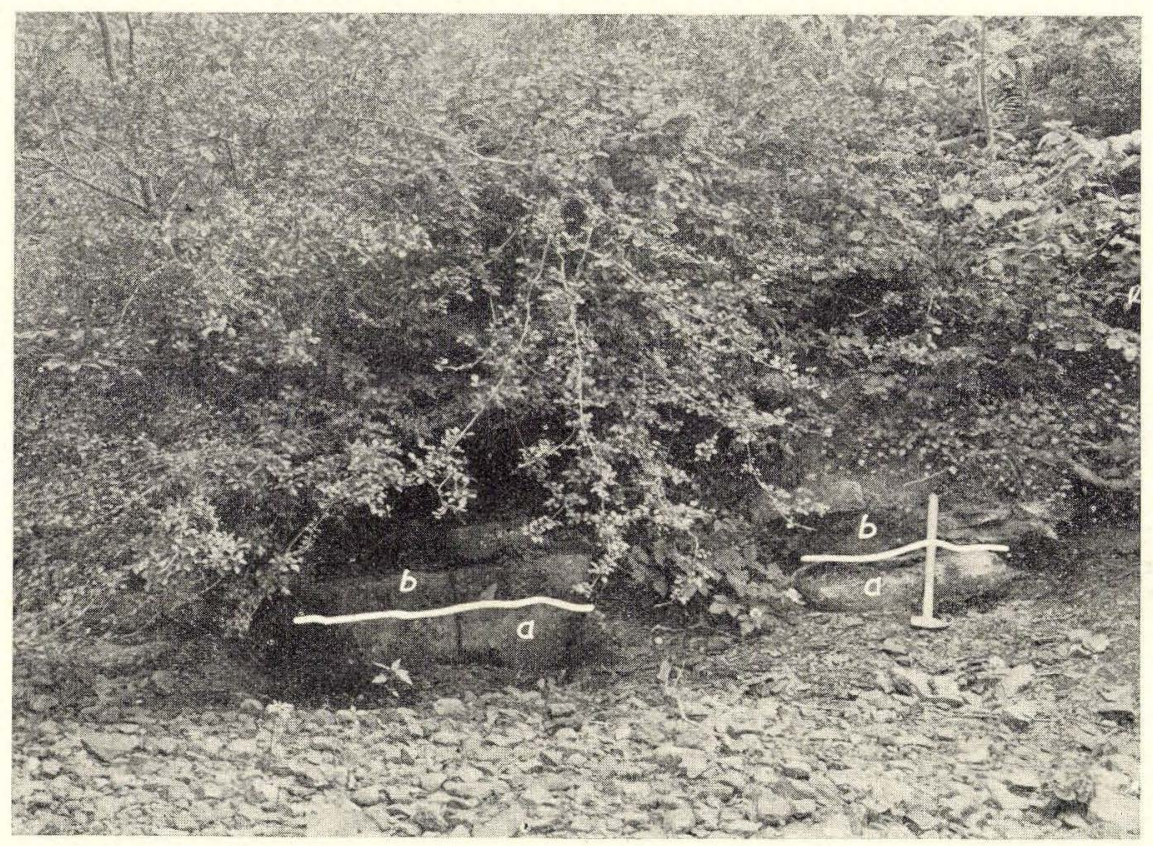

Fig. 9. The limestone bed in the Davidis and Forchhammeri Zones in Loc. II at the Læsaa. a. Lime-sand limestone of the Davidis Zone. b. Andrarum Limestone.

domed surface of the substratum. The phosphorite nodules were previously described by DeEcke (1897), but his description is difficult to reconcile with the present writer's observations, due no doubt to the fact that DEECKE treats together several things that should properly be kept apart.

PI. II, fig. 3 is a thin section of one of these phosphorite nodules. The white areas consist of clear, crystalline calcite in the form of reticulated calcite veins. Here the crystals are somewhat coarser than in the ground-mass of the conglomerate. The grey areas look brown in the thin sections and are not double-refractive. As a consequence they probably consist of phosphate of lime. The same applies to the black areas, which also contain considerable quantities of black organic material. 
A few of the nodules consist of more homogeneous, dense brown phosphorite without calcite veins.

The ground mass in the conglomerate consists of grey crystalline limestone of the same type as that shown in pl. II, fig. 1. It contains

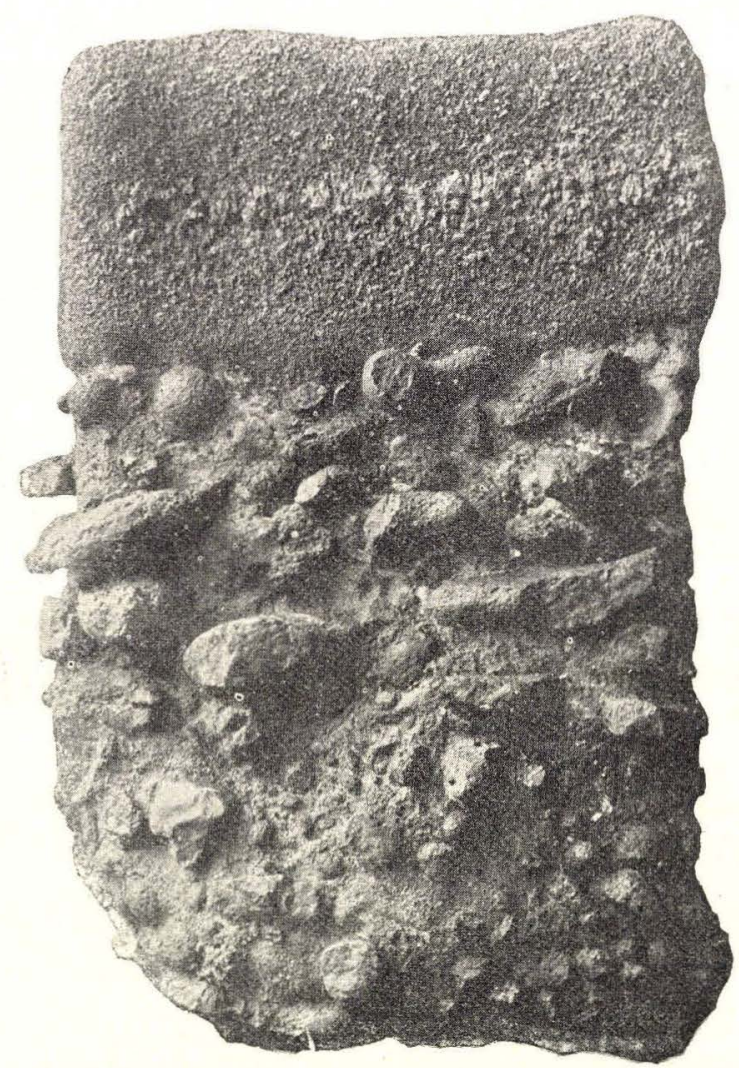

Fig. 10. Phosporite nodules in the stinkstone bed with Paradoxides davidis Læsaa Loc. II. (After Giönwall 1902).

numerous shell fragments and here and there small quartz grains. The nodules contain 22 per cent. $\mathrm{P}_{2} \mathrm{O}_{5}$. GRönwaLl estimates the thickness of the Davidis Zone at $25 \mathrm{~cm}$. (Grönwall 1902), which must be the maximum. Vertical calcite crystals or faint "cone-in-cone" structure occurs in the upper part of the zone, but somewhat rarely.

Over the lime-sand limestone of the Davidis Zone lies a shelly conglomerate, which has a thickness of $5 \mathrm{~cm}$. Grönwall describes this as the transitional deposit between the zones containing Paradoxides davidis and Paradoxides forchhammeri. The conglomerate consists of an accumulation of shell fragments, large and small mixed together. 


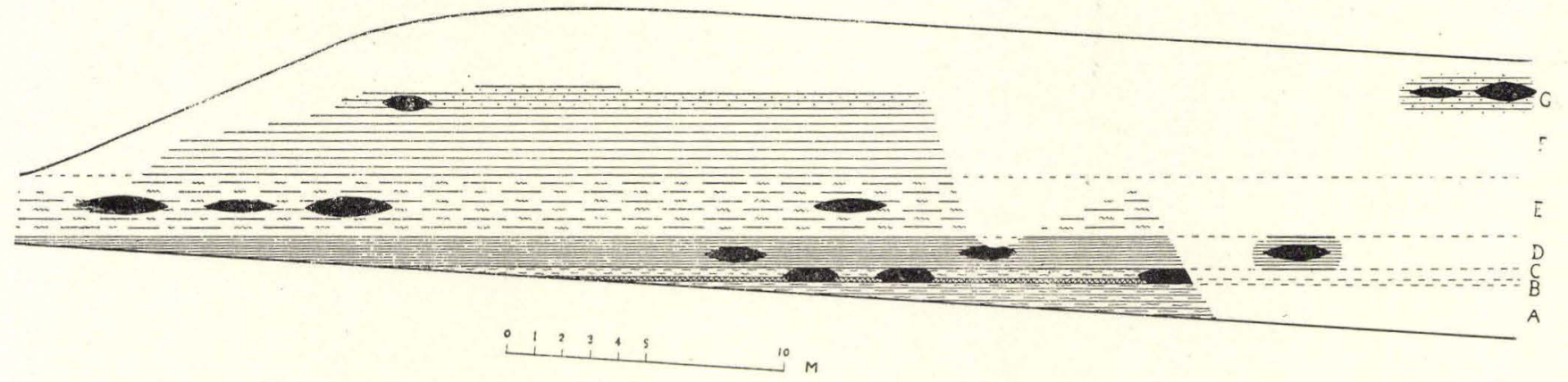

Fig. 11. The section in Loc VII at the I

Orusia lenticularis, B = with Eurycare latum, C = Poulsen 1923. A = Zone with

with Ctenopyge flagellifera, $\mathrm{E}=$ with Ctenopyge tumido, Eurycare angustatum, $\mathrm{D}=$ baeoides, $\mathrm{G}=$ with $P$. scarabaeoides and Parab, $\mathrm{F}=$ with Peltura scara- 
In addition, there are a few local accumulations of small quartz grains. Pyrites occurs in the form of brassy-yellow nodules and cubic crystals. Barite is also present in rather considerable quantities, someiimes interspersed with the calcite in exactly the same manner as the quartz and felspar in the graphic granites (pl. IV, fig. 3). "Cone-in-cone" structure occurs here and there. Grönwall states that the fauna in this conglomerate includes a mixture of the fauna in the Paradoxides davidis Zone and that in the Paradoxides forchhammeri Zone. Overlying the shelly conglomerate is Andrarum Limestone, with a thickness of $45 \mathrm{~cm}$. As at the Øleaa it consists of finely re-crystallized calcareous mud with shell fragments. The colour is black or grey and varies somewhat from place to place, lighter and darker deposits alternating irregularly. The shells, too, seem to be irregularly distributed. Pyrites occurs rather frequently in the form of brassy crystals, accretions or thin smears. In the upper part especially there are large nodules of pyrites as well as pure white calcite. Grönwall states that this limestone also contains gypsum crystals $3-4 \mathrm{~cm}$ long, as well as irregular round nodules of phosphorite or of a highly phosphoritic, impure limestone.

Over the Andrarum Limestone lies alum shale with large lenses of stinkstone. These are very hard and almost unbreakable. The marginal zone is coarsely crystalline, in some places with a stemmy structure, in others with large normal ground-rhombohedra. This alum shale is of the same type as those over the Andrarum Limestone at the Øleaa.

The strata dip $10^{\circ}$ towards $10^{\circ} \mathrm{W}$.

Locality III. Just above the bridge is a black shale cleaving into rather thick laminae with almost flat planes. No fossils have hitherto been found here. The strata dip $10^{\circ}$ towards $\mathrm{S} 14^{\circ} \mathrm{W}$.

Locality IV. Just below the bridge is a hard alum shale with flat cleavage planes showing numerous impressions of Olenus. A few metres farther down the river there is a limestone bed about $40 \mathrm{~cm}$ thick in the river bed. This limestone bed consists of finely crystalline black limestone. The surface is uneven and domed, the explanation no doubt being that immediately over the limestone and merging with it lie two stinkstone lenses consisting of coarsely crystalline stemmy calcite. In the left bank at a slightly higher level are two calcareous lenses which are also coarsely crystalline in their upper part and show "cone-incone" structure. These lenses lie in alum smale with Olenus. 
Locality V. Just before the bend in the river below Locality IV there is black alum shale in the left bank. At some places the shale lies in flat undulations, suggesting that it contains stinkstone lenses. POulsen (1923) found Homagnostus obesus in this shale.

Locality VI. In the next bend there is again alum shale with small barite concretions of the size of a fist. In almost every case they consist of black crystalline barite, which forms long narrow crystals radiating to all sides from the centre of the under side of the concretion. POULSEN writes that here he found badly preserved specimens af Orusia lenticularis (Poulsen 1923).

Locality VII. In the bed of the river are four stinkstone lenses having a maximum horizontal axis of about $1 \mathrm{~m}$. They consist entirely of finely crystalline limestone.

A few metres lower down there is a bed of stinkstone in the left bank. At the base it consists of a very thin stratum of black limestone with "cone-in-cone" structure. Over it is again black, thinly-bedded crystalline limestone with numerous Orusia shells. This group has a thickness of $3 \mathrm{~m}$. Overlying it is from 6 to $10 \mathrm{~cm}$ of finely crystalline limestone, though at the base it is a little coarser but without "cone-in -cone" structure. The upper $2-3 \mathrm{~cm}$ contains immense quantities of Orusia shells. Thus the total thickness varies somewhat from place to place, owing to the fact that the surface of the limestone bed is not plane, but covered with semispherical limestone humps. In this bed too there are numerous small crystals of barite.

Locality VIII. In the right bank of the river there is a section in alum shale and stinkstone lenses, measuring about $60 \mathrm{~m}$ long and about $10 \mathrm{~m}$ in height. As fig. 11 shows, these lenses lie arranged in rows with a faintly southerly dip. The dimensions are quite considerable. The horizontal axis sometimes reaches a size of $1.5 \mathrm{~m}$ and the thickness about $0.5 \mathrm{~m}$. The stratigraphy of this section was described by Poulsen in 1923 and represents the upper part of the zone with Orusia lenticularis, the zone with Eurycare and Leptoplastus, the zone with Ctenopyge and a part of the Peltura Zone. The lenses are all entirely black, rub off readily and consist mainly of finely crystalline limestone with a very high percentage of black sulphidic and organic mud, which forms black winding bands between the crystals and sometimes gives them a very irregular form. Here and there are somewhat coarser crystals, but stemmy structure occurs only uppermost in the Peltura Zone. The coarser parts of the other lenses seem chiefly to be in there upper part, whereas the lower parts are often 
thinly bedded and display a fairly gradual transition from the shale to the limestone.

The shale is coal black, laminated with flat cleavage planes which are entirely covered with a yellow powder. Here they contain numerous small folious gypsum crystals and fusiform crystals of barite (CALLISEN 1914).

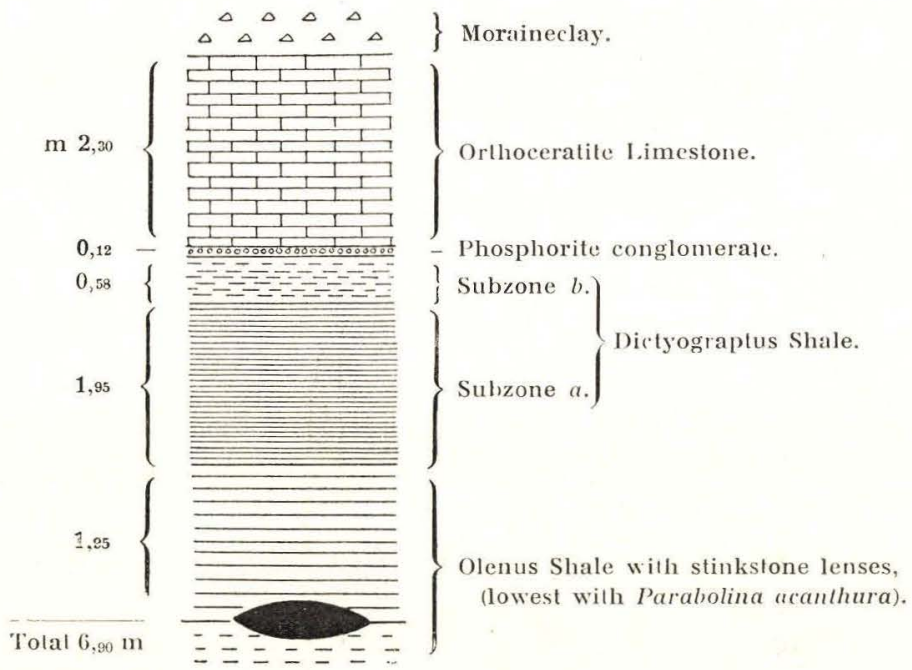

Fig. 12. Section through the sediments at Limensgade Loc. X. (After Poulsen 1922).

Locality IX. Just in the bend of the river below the high section there are five stinkstone lenses in the river bottom; they have a coarsely crystalline peripheral marginal zone, but no stemmy structure. Somewhat lower down the river in the right bank is a small section in alum shale, about $1.2 \mathrm{~m}$ high, with Peltura scarabaiodes (Grönwal. 1902, Poulsen 1923). Along the whole stretch of the river bed down to the Ortheroceratite Limestone there are several stinkstone lenses with coarsely crystalline marginal zones but without stemmy structure.

Locality $\mathbf{X}$. The stretch from Locality IX down to Limensgade is occupied by deposits belonging to the Ordovicium. The Upper Cambrian does not reappear until we reach the bottom of the old slate quarry at Limensgade (fig. 12). Here low down are some large stinkstone lenses, and overlying them non-fossiliferous alum shale which Poulsen (1922 and 1923) places to the Acerocare Zone. The stinkstone is dense or finely crystalline in the central parts, where it contains a few large pale calcite crystals in the form of phenocrysts. Upwards the limestone becomes more and more coarsely crystalline and stemmy, and uppermost it consists of large calcite crystals arranged in parallel. 


\section{Chapter II. Stratigraphy and Fauna.}

The stratigraphy of Bornholm's Middle and Upper Cambrian was described by Grönwall (1902) and Poulsen (1923), and there is nothing new to add to their conclusions. The various zones are divided according to the following table.

\begin{tabular}{|c|c|c|c|c|}
\hline \multirow{7}{*}{ 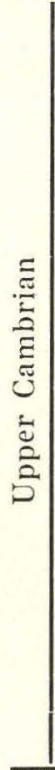 } & Zones & Sub-Zones & $\begin{array}{l}\text { Læsaa } \\
\text { Loc. }\end{array}$ & $\begin{array}{l}\text { Øleaa } \\
\text { Loc. }\end{array}$ \\
\hline & 6. Acerocare Zone & $\begin{array}{l}\text { Unfussiliferous shale. } \\
\text { Parabolina acanthura }\end{array}$ & $\mathrm{X}$ & \\
\hline & $\begin{array}{l}\text { 5. Zone with Peltura, } \\
\text { Sphaeroptalmus and } \\
\text { Ctenopyge }\end{array}$ & $\begin{array}{l}\text { Parabolina longicornis } \\
\text { Peltura scarabaeoides } \\
\text { Ctenopyge lumida } \\
\text { Ctenopyge flagellifera }\end{array}$ & $\begin{array}{l}\text { VIII-IX } \\
\text { VIII } \\
\text { VIII } \\
\text { VIII }\end{array}$ & \\
\hline & 4. Eurycare Zone & $\begin{array}{l}\text { Eurycare angustatum } \\
\text { Eurycare latum }\end{array}$ & VIII & 14 \\
\hline & 3. Orusia Zone & $\begin{array}{l}\text { Parabolina spinulosa and } \\
\text { Orusia }\end{array}$ & VI-VIII & $11 \& 13$ \\
\hline & 2. Olenus Zone & $\begin{array}{l}\text { Olenus and Homagnostus } \\
\text { obesus }\end{array}$ & IV & $8-10$ \\
\hline & $\begin{array}{l}\text { 1. Zone with Agnostus } \\
\text { pisiformis }\end{array}$ & Agnostus pisiformis & III & 7 \\
\hline \multirow{4}{*}{ 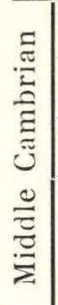 } & 4. Laevigata Zone & Lejopyge laevigata & II & 5 \\
\hline & 3. Forchhammeri Zone & Paradoxides forchhammeri & II & 56 \\
\hline & 2. Davidis Zone & Paradoxides davidis & II & 56 \\
\hline & 1. Tessini Zone & $\begin{array}{l}\text { Bailiella aequalis } \\
\text { Hypagnostus parvifrons } \\
\text { Ctenocephalus exsulans }\end{array}$ & I & $\begin{array}{l}4 \& 5 \\
3-4 \\
1-4\end{array}$ \\
\hline
\end{tabular}

Compared with Andrarum the series is rather incomplete. In the Middle Cambrian there are large lacunae. The zone with Paradoxides 
olandicus is missing, and GRöNwaLL already drew attention to the fact that in this particular period Bornholm at times lay emerged, at other times submerged, and in this he is supported by Poulsen (1942).

The other two sub-zones of the Tessini Zone differ somewhat in their development at the Læsaa and the Øleaa, and both faunistically and stratigraphically this part of the series is very different from the series at Andrarum. Grönwall drew up the folowing comparative table.

\begin{tabular}{l|c|c}
\hline \multicolumn{1}{c|}{ Andrarum } & Øleaa & Læsaa \\
\hline $\begin{array}{l}\text { Sub-zone with Bailiella } \\
\text { aequalis }\end{array}$ & $\begin{array}{c}\text { Sub-zone with } \\
\text { Bailiella aequalis }\end{array}$ & $\begin{array}{c}\text { Sub-zone with } \\
\text { Bailiella aequalis }\end{array}$ \\
$\begin{array}{c}\text { Sub-zone with Condylopyge rex } \\
\begin{array}{c}\text { Sub-zone with Triplagnostus } \\
\text { intermedius }\end{array}\end{array}$ & $\begin{array}{c}\text { Sub-zone with Hypag- } \\
\text { noslus parvifrons }\end{array}$ \\
$\begin{array}{c}\text { Sub-zone with Eodiscus } \\
\text { scanicus }\end{array}$ & \\
\hline
\end{tabular}

It is thus evident that in Bornholm there cannot be the same fine zonal division as at Andrarum; at the Øleaa the fossils of the three lower sub-zones are mixed together, and therefore GrönwaLL places them to one sub-zone with Hypagnostus parvifrons. At the Læsaa we know of no fossil that is characteristic of this sub-zone (GRönwaLL 1902), and presumably its equivalent is the pyritic conglomerate overlying the Exsulans Limestone.

In the Upper Cambrian the series is more complete, with no lacunae. On the other hand the fauna is distinctly poor in species, compared not only with Scania but also with the other Swedish localities. This is especially so in the Orusia Zone, where there is an almost total absence of Trilobites; and almost the same applies - but to a less marked degree — to the Acerocare Zone and the zone with Agnostus pisiformis. This may be due to the fact that fossils preserve better in limestone than in shale, and the two last-named zones in Bornholm are relatively poor in stinkstone lenses. However, it is not quite certain that this explanation is the correct one; for an examination of the fossil horizons in the section at Locality VIII at the Læsaa shows that the fossil frequency in the shales and in the limestone lenses is very nearly the samc, and at Locality 10 at the Oleaa the shale is crowded with fossils (Homagnostus obesus). As regards the Acerocare Zone, only its lowest sub-zone with Parabolina acanthura can be divided off with certainty, and this is overlain by unfossiliferous shale. On the other hand, there is nothing in the sediments to suggest an interruption of the sedimentation. 


\section{Chapter III. \\ The Mode of Sedimentation.}

In an endeavour to visualize the conditions under which a series of sediments was laid down, as many as possible of the characteristics of the sediments must be taken into consideration and the cause of their presence must be discussed thoroughly. Likewise, a systematic examination of the particular series at the chosen spot, combined with continual comparisons with developments in the nearest areas where the same series occurs, will be necessary in order to establish continuity in these developments and in order to fit them into their proper place in the whole. As regards the Bornholm Cambrian this principle has previously been followed for the Lower Cambrian group (KAJ HANSEN 1936, 1937), and therefore our present account may begin with the sediments of the Middle Cambrian group.

\section{a. Middle Cambrian.}

After the deposition of the Rispebjerg Sandstone Bornholm lay above the sea level, or at any rate just at the surface, and formed the south coast of part of the Baltic Sea. The upper, partially phosphatized part of the Rispebjerg Sandstone was thereby exposed to a certain amount of erosive action, which broke down the more friable parts but did not remove much of the loosened material. As a consequence the surface of the sandstone became very uneven and full of pits and hard summits. The height difference between the lowest and the highest levels was sometimes about $40 \mathrm{~cm}$. On this uneven surface the Exsulans Limestone was then deposited (see fig. 5).

The clastic components of the Exsulans Limestone originate almost entirely from the underlying or surrounding Rispebjerg Sandstone, or from organisms that lived in the environs. There is no reason for assuming that the material was transported from any great distance away. 
It is more difficult to form an opinion as to whether the glauconite is autochthonous or allochthonous. In any case, its occurrence in the form of irregular, soft accretions suggests that it was freshly precipitated and soft when it was deposited, but it is hardly probable that it was precipitated on the spot, as the environment there does not seem to have been favourable for glauconite precipitation. It should rather be assumed that it was formed farther out in somewhat deeper water and was carried into the shallow water by tidal currents or wave action.

As the Exsulans Limestone now presents itself it is a pale grey finely crystalline or dense limestone; but it is very difficult to decide whether this structure is primary or due to later re-crystallization. In order to judge the conditions under which the Exsulans Limestone was deposited, it will be necessary to examine somewhat more closely the conditions for calcium carbonate precipitation in the sea at the present time. This may have taken place either 1) biogenetically or 2) abiogenetically.

Pra divides the biogenetic precipitation of calcium carbonate into two groups (PIA 1933):

$$
\begin{aligned}
& \text { Organic precipitation, } \\
& \text { Physiological precipitation. }
\end{aligned}
$$

To organic calcium precipitation PIA places reefs and eupelagic calcium deposits, i. e. deposits consisting of the hard calcareous skeleton or shell of the organisms. Of these two groups the latter may be disregarded at once, as the clastic components of Exsulans Limestone makes it evident that it was deposited in very shallow water near the coast. Cambrian alga reefs are known in North America, it is true, but nowhere in Scandinavia, and in fact there is nothing in the structure of the Cambrian limestone in Bornholm to recall Archaeocyatus or calcareous algae such as those illustrated by WALCOTT $(1914,1916)$ or Schuchert \& Dunbar $(1933,1934)$. However, Walther (1885) demonstrates that such alga-calcium reefs are readily deprived completely of their original structure and are converted into quite structureless limestone. But the slight thickness of Exsulans Limestone and especially the high content of clastic material in the lower part make it very difficult to regard it as a reef limestone.

Of the physiological calcium-carbonate-precipitating processes the only ones that can come into consideration in a discussion on the origin of Bornholm limestones are those proceeding in collaboration with micro-organisms, particularly bacteria. This precipitation may take place under various conditions, but it is very closely associated with stagnant water containing large quantities of decomposing organic 
material accompanied by the generation of hydric sulphide. It is difficult to imagine such conditions during the sedimentation of the Bornholm Exsulans Limestone, but perhaps during the deposition of tho stinkstones (see further p. 35).

Abiogenetic calcium carbonate precipitation in the sea is due to an increase in the concentration of dissolved $\mathrm{CaHCO}_{3}$ as a result of 1) evaporation, 2) loss of $\mathrm{CO}_{2}$ to the atmosphere owing to changes in the atmospheric carbon-dioxide tension, 3) loss of $\mathrm{CO}_{2}$ to the atmosphere owing to an increase of the sea-water temperature.

If abiogenetic calcium carbonate precipitation is to take place at all, it is furthermore necessary that the sea water at the spot should be saturated with dissolved bicarbonate of calcium. Johnston \& WILLIAMSON assume that this is the case with the surface water in the warm seas, whereas in the deeper layers and in the polar regions as well as in cold streams the water is not so saturated, on the surface or deeper down (Johnston \& Williamson 1916). Vaughan subscribes to this assumption on the basis of many experiments at the Tortugas Laboratory (VAUGHAN 1917).

Calcium carbonate precipitation in the sea as a result of evaporation plays a very subordinate rôle and can take place only in the immediate vicinity of coasts with a very warm and dry climate. BEHREND \& BERG (1927) as well as CLARKE (1924) state that when rivers with a very high content of dissolved calcium carbonate reach the sea at places where thero is active evaporation, there will be a supersaturation and some of the calcium will be precipitated off the mouths of such rivers and along the coast for some distance along either side. To this, however, JoHnSTON \& WILLIAMSON object that a fairly considerable part of the demonstrable calcium carbonate content in river water is not transported in a dissolved state but in suspension, and that at the river mouth there is therefore a coagulation of the calcium carbonate as well as of the other colloids. The final results, i. e. a calcium carbonate precipitation, will however be the same in both cases.

Calcium carbonate precipitation as a consequence of changes in the $\mathrm{CO}_{2}$ tension of the atmosphere is credited with great importance by e. g. Johnston \& Williamson as well as Vaughan, whereas others like PIA seem to consider it quite subordinate. PIA raises the further objection against JoHnston \& Williamson's conclusions that they are merely theoretical possibilities which have not been confirmed by observations in nature (PIA 1933).

Calcium carbonate precipitation caused by sea water giving off part of its $\mathrm{CO}_{2}$ content as a result of heating seems to be the most important 
of the abiogenetic calcium precipitation processes. JoHnston \& WILLIAMSON say that if cold bottom water comes up to the surface under such conditions that it is thereby heated, it will throw off part of its $\mathrm{CO}_{2}$ content, and thus there will be a possibility of a supersaturation of calcium carbonate, whereby some of it will precipitate. In deep water this precipitated calcium will sink down into colder strata containing more $\mathrm{CO}_{2}$, where it will again be dissolved so that under such circumstances the calcium carbonate completes the cycle. But if the ascending water is driven into shallow water at the coast or over submarine banks, there will at these places be an abiogenetic calcium precipitation on the sea floor. BLACK states for instance that by the increase of temperature of the water that is driven from the Gulf Stream in over the Great Bahama Banks, where the depth of water is nowhere more than $6 \mathrm{~m}, 6.23 \mathrm{~g}$. of solid $\mathrm{CaCO}_{3}$ is precipitated per cubic metre of water, which corresponds to a layer $0.0338 \mathrm{~m}$ thick of aragonite mud in the form of fine acicles (BLACK 1933).

There is actually no reason why the Bornholm Exsulans Limestone should not have been formed by such an abiogenetic calcium precipitation in shallow water near the coast.

Finally, there is a last possibility, viz. that the calcareous mud was transported in a state of suspension and was simply sedimented in the form of very fine ooze in places where the water was sufficiently calm.

The high content of coarse grains of quartz and the phosphorite nodules on the surface of the green limestone show that the calcareous mud very soon after sedimentation must have hardened so much that it was able to prevent these clastic components from sinking down through it. It is difficult to say whether this hardening proceeded above the water surface or under it; but it may be recalled that on Andros Island in close association with the sedimentation there proceeds a fixation of the calcareous mud by the aid of algae which permeate the mud with their filaments (BLACK 1933), just as at certain places in the marsh along the South Jutland West coast the filaments of the Cyanophyceae help to retain the ooze deposited by the tidal streams.

The suggestion has been made that the salinity of sea water in Cambrian times was different from that of today, both as to concentration and as to composition (Daly 1912, Clarke 1924, Pia 1931), the salt content having become steadily higher. PIA maintains that in fresh water the precipitation of calcium, as a result of the reduction of $\mathrm{CO}_{2}$ in the water due to the assimilation of carbon dioxide by the plants, plays a much greater rôle than in the sea, but that there has not always been this difference, as many palaeozoic marine alga lime- 
stones can be compared only with the physiological alga limestones which one meets with in fresh water nowadays, and which were formed in the manner described above.

Bornholm Exsulans Limestone seems more likely to have been formed by abiogenetic calcium carbonate precipitation or by the sedimentation of suspended calcareous mud carried by tidal streams or by wave action over a shallow, flat sea floor very close to the coast, perhaps on a bench or shore-face terrace (Johnson 1919). This breaks the waves a good distance out from the shore, and the water over the terrace becomes relatively smooth while at the same time the transportation of material proceeds in towards the land.

The thin sandy deposit with small grains of quartz and glauconite and accumulations of shell fragments encountered now and then on the surface of the Exsulans Limestone, together with the always very sharp boundary between that limestone and the overlying stinkstone at the Øleaa, indicates that the Exsulans Limestone had hardened and its upper part had been exposed to some erosion before the stinkstone was deposited. With the deposition of this stinkstone an extraordinary change took place in the surrounding conditions. Whereas the Exsulans Limestone was deposited in relatively fresh and highly oxygenous water, the whole of the overlying part of the Cambrian was laid down under stagnant conditions.

These stagnant conditions in the water may have been due either to a marked and constant rise in the specific gravity of the water from the surface down towards the bottom, whereby convection currents and with them the deäeration of the lower layers would be inhibited or entirely prevented, as in the case of the Black Sea today (Androussow 1897, Murray 1900, Archanguelsky 1927, Strøm 1936), or to the presence of overwhelming quantities of putrefying organic material as in the case of the Russian limans, the bay at Hapsal and on Øsel and in the marshes and coastal swamps. In both cases considerable quantities of sulphuretted hydrogen develop. In deeper waters like the Black Sea the processes are capable of being visualized according to the following schema (TwENHOFEL 1926).

The sulphuretted hydrogen is formed at the bottom 1) by the decomposition of various proteins with the aid of decomposition bacteria, a process which is promoted by the exclusion of oxygen and the presence of peptone (HARDER 1919); 2) by the reduction of sulphates by means of anaerobic desulphurating bacteria. The sulphuretted hydrogen thus formed diffuses up through the water, where it serves as a nutrient for the sulphur bacteria. These bacteria, which either are aerobes but adapted to a low oxygen pressure, or anaerobes, 
Sea surface

Oxygen diffuses from the air down into the water.

$\downarrow \uparrow$

Limit of optimum conditions for sulphur bacteria and for the formation of sulphur and sulphates.

Sulphur and sulphates sink towards the bottom and sulphuretted hydrogen diffuses up through the water.

$\downarrow \uparrow$

Near the bottom and in the bottom sediment live desulphurating and sulphuretted-hydrogen-forming bacteria.

as they can procure the necessary oxygen from the assimilation of carbon dioxide (BAVENDAM 1924), in the Black Sea occur at a fairly limited level so situated that sufficient oxygen and light can penetrate from above and sufficient sulphuretted hydrogen from below. The sulphur bacteria oxidize the sulphuretted hydrogen to sulphuric acid, which in turn combines with the sea water's $\mathrm{Na}, \mathrm{K}$ and Ca salts to sulphates, which sink to the bottom where they are attacked by the desulphurating bacteria, which reduce them to sulphuretted hydrogen. As a result of the decomposition at the bottom there are formed besides the sulphuretted hydrogen — large quantities of ammonia; this ammonia combines with the $\mathrm{CO}_{2}$ in the water and forms ammonic carbonate, which further react with the sulphates and forms calcium carbonate, which is precipitated on the sea bottom. In deeper water, and in places where the supply of terrigenous material is very small, the chief result of the stagnating process is thus a precipitation of calcareous mud, whereas the sulphur passes through a complete cycle. Accordingly, on the bottom of the deepest parts of the Black Sea, where the supply of terrigenous material is practically nil, and where also the annual addition of organic material is relatively small and originates solely from the year's production of plankton, we find a pure white calcareous mud with thin black bands of organic substance. Nevertheless the stinkstones contain considerable quantities of iron sulphide and accordingly were not formed under conditions such as those prevailing in the deeper parts of the Black Sea. If the sulphur is to evade the cycle the water must contain such dissolved components as will enter into indissoluble combination with the sulphuretted hydrogen, for example iron and copper (SchneIDERHörn 1923). In 
that case part of the sulphuretted hydrogen goes towards the formation of sulphides. However, seawater's content of ferreous salts is very low, so that the iron must be brought in from the outside, either in the form of terrigenous material containing iron or originating from organisms.

Actually we know very little about the processes whereby iron is freed from the ferric silicates. Doss's explanation of the presence of ferrosulphide in the sediments is that the iron is freed by the breaking down of ferreous minerals or by cellulose fermentation, and then transported by the streams to lagoons etc. as $\mathrm{Fe}\left(\mathrm{HCO}_{3}\right)_{2}$. There it is precipitated either directly as a colloidal ferrosulphide as a result of reaction with sulphuretted hydrogen, or as ferrihydroxide precipitated by iron bacteria. The ferrihydroxide is then reduced to ferrosulphide (Doss 1912). On the other hand, ScHucht's investigations show that in the Elbe all dissolved iron disappears already in the brackish-water zone and that practically none of it is carried out to sea (ScHucht 1904). Harder believes that the ferreous sulphide is formed in two different ways. 1) By means of bacteria, which reduce the sulphates, and 2) by reaction between the sulphuretted hydrogen and dissolved ferreous salts (HARDER 1919). In any case, it would seem that the formation of ferreous sulphide is conditioned by the supply of terrigenous material, which no doubt in most cases will consist of ferreous silicates. As regards the Cambrian sediments it is presumable that a large part of the finer terrigenous material was transported from regions of red continental sandstone. By means of chemical and bacterial processes in the precipitated mud these originally red iron oxides would be converted into black ferrosulphides. This agrees with the fact that the content of ferreous sulphide as a rule is higher in the shales than in the limestones. A determination of the FeS content, made at the laboratory of Denmark's Geological Survey, gave the following result:

\begin{tabular}{llrr} 
& \multicolumn{3}{c}{$\begin{array}{r}\text { FeS r } \\
\text { per cent. }\end{array}$} \\
Peltura Zone's calcareous lenses $\ldots \ldots \ldots \ldots$ & 2.85 & 5.1 \\
Orusia Zone's limestone bed $\ldots \ldots \ldots \ldots \ldots$ & 2.91 & \\
Orusia Zone's alum shale $\ldots \ldots \ldots \ldots \ldots \ldots$ & 14.45 & 8.2 \\
Davidis Zone's limestone bed $\ldots \ldots \ldots \ldots \ldots \ldots$ & 1.32 & 2.1 \\
Lower alum shale $\ldots \ldots \ldots \ldots \ldots \ldots \ldots \ldots$ & 7.07 & 2.6
\end{tabular}

From what has been said above it appears that in stagnant water there is a production both of sulphuretted hydrogen and ammonia and of sulphates, and these, together with the ammonia produced at the 
bottom, cause the formation of the calcareous mud. In deep waters like the Black Sea the sulphuretted hydrogen and the sulphates are produced each at its own level a considerable distance apart. In shallower waters, such as the limans and in the littoral zones of the open sea, the two levels are much closer together, the sulphate being produced just in the surface of the mud, whereas the sulphuretted hydrogen and the ammonia are produced deeper in the mud. Accordingly, the mud in the Russian limans contains up to 33.21 per cent. calcium sulphate (the Kuljanik liman) and up to 38.30 per cent. calcium carbonate (the Dnjeper liman) (GoEBEL 1857).

On the Gr. Bahama Bank in the West Indies the depth of the water is nowhere in excess of $6 \mathrm{~m}$, in most places only $2-3 \mathrm{~m}$. The sea floor consists of an incoherent white calcareous mud which whirls up at the slightest movement in the water. BAVENDAM and BLACK draw the exceedingly important conclusion that not the open sea but shallow lagoons, gulfs and mangrove swamps with bluish-grey mud sulphuretted hydrogen containing large quantities of organic detritus, are the principal seats of microbiological precipitation of calcium carbonates. A contributory cause of this precipitation is a whole series of groups of bacteria, of which the ammonia-producing and the decompositing bacteria play the greater rôle, whereas denitrifying bacteria and those which break down organic calcareous salts as well as the desulphurating bacteria are more subordinate (BAVENDAM 1932, BLACK 1933). From this it would appear that in the present day besides in deeper water a very active precipitation of calcium may proceed in lagoons having a high salinity and in the littoral zone of the open sea. The intimate mixture of calcium, ferreous sulphide and black organic matter in the Bornholmian limestones shows that they were deposited in water no deeper than that wave action was able to keep the superficial layers in constant motion.

After this examination of the chemical and bacterial processes that give rise to a precipitation of calcium carbonate, we may return to the stinkstone bed overlying the Exsulans Limestone at the Øleaa on Bornholm.

As was stated in the above, the surface of the Exsulans Limestone must have been hardened and exposed to some erosion prior to the deposition of the stinkstone, and this might suggest that the stinkstone is to be regarded as a transgressional deposit laid down in the littoral zone through the precipitation of calcareous mud under stagnant conditions. As was stated on page 10 one encounters spor- 
adically in this stinkstone bed a curious fine stemmy "cone-incone" structure (figs. 2 and 3 , p. 11), and in those parts of the limestone bed where this structure has not developed there is a structure reminiscent of that shown in pl. I, fig. 3, with larger and smaller sub-angular grains of calcite in a ground-mass of black organic mud. It has been shown earlier (KAJ HANSEN 1938) that the "cone-in-cone" structure here must be regarded as a peculiar form of crystallization in the calcite, and that this may possibly be due to the effects of sulphates in the solution from which the calcite crystallized. It was also shown that for this to take place, this crystallization must have proceeded in immediate association with the bacterial precipitation of calcium carbonate in black mud containing sulphuretted hydrogen, where as was mentioned above there is also a production of sulphate at the surface. If the necessary concentration of the sulphates was to be attained, crystallization must have taken place in a lagoon with a high salinity or in pools on the surface of the littoral zone.

If we imagine that these elongated crystals of calcite were formed on the surface of the littoral zone during low tide, some of them would be liable to be washed loose and broken up when at high water the sea again flowed over the surface (negative sedimentation, HADding 1927), whereafter the fragments would be transported and deposited in the form of calcite grains of the same habitus as the grains of calcium carbonate in the other part of the limestone bed. Accordingly the latter might be regarded as lime-sand limestone deposited in or over the other part just outside the littoral zone. It must be observed, however, that Professor HADDing of Lund informs me that according to his experience in the study of a large material of Swedish stinkstone, the formation of calcite crystals with curved planes and on the whole with the same habitus as those shown on pl. I, fig. 3 is due solely to the presence of enormous quantities of black organic impurities which inhibit the growth of the crystals. The fact is that calcareous mud has a tendency to crystallize into pure calcite without impurities. In this manner the black impurities concentrate more and more between the calcite crystals gradually as crystallization proceeds (KAISIN 1926). If the impurities are present in very large quantities they will eventually prevent the calcite individuals from growing together into a crystal mosaic of the type found e. g. in Exsulans Limestone (pl. I, fig. 2). This does not quite agree with what we know of Bornholmian stinkstones, as the calcareous lenses in Bornholmian Upper Cambrian contain many more impurities without having these peculiar structures. The littoral character of the stinkstone is made more probable by the fact that at the Læsaa its equivalent is a pyritic conglomerate con- 
taining quartz grains, fragments of Rispebjerg Sandstone and of Green Shales (GRönwall 1902).

After the sedimentation of the stinkstone bed there was an increase in the supply of fine terrigenous mud, which must have been deposited in very calm water and presumably at a somewhat greater depth. The limestone no longer occurs in the form of continuous beds but as calcareous lenses. Conditions in Locality 6 (fig. 7) show that these calcareous lenses must have been solid and must have assumed their present shape prior to the sedimentation of the limestone bed in the zone with Paradoxides davidis, for the latter's underside is concordant with the unevennesses in the underlying shale surface due to the lenses and the intervals between them.

If we imagine that the black calcareous mud and the black terrigenous mud formed co-ordinated belts on the sea floor, with the former belt lying nearer the shore (an assumption that seems plausible partly because of conditions today at Andros Island, and partly because at Öland and in Västergötland conglomerates and other signs of littoral sedimentation always lie in close association with coherent continuous limestone beds), these two belts of course will not be sharply delimited; one must be prepared to find larger or smaller local patches of calcareous mud in the inner part of the terrigenous mud belt. As the boundary between the two belts of course is in a constant state of displacement to and fro, these patches of calcareous mud wherever they are will continue to exist for a time only, and then disappear, to be followed by new patches elsewere. It is therefore easy to imagine that these patches of calcium carbonates would form the nucleus of the calcareous lenses in the alum shales. This of course does not preclude the possibility that later on, at any rate in some cases there has been an additional secondary accretionary growth of these lenses and a re-crystallization of their marginal zone (see also p. 49). The shales with the large calcareous lenses were in reality deposited in rather deeper water and at a greater distance from the coast than the continuous limestone beds and represent the border zone between limestone and mud facies.

In the zone with Paradoxides davidis the deposition of fine terrigenous mud ceases and the precipitation of calcium carbonate-again becomes predominant. Here again the limestone bed has almost the character of a lime-sand limestone (pl. I, fig. 3), formed outside of the littoral zone by the deposition of more or less rolled fragments of washed-out and broken elongated calcite crystals with "cone-incone" structure from the littoral zone. 
This off-shore and shallow-water nature of the limestone beds of the Davidis zone is also pointed out by GRönwALL (1902) and is made more probable by its phosphorite conglomerate. As this conglomerate contains scattered rolled quartz grains, but no fragments of phosphorite sandstone, it would seem that these quartz grains must originate from the breaking down of the sandy Exsulans Limestone, so that their presence suggests that there was a land surface not very far away with exposed areas of Exsulans Limestone.

As was stated in a previous work (KAJ HANSEN $1937 \mathrm{~b}$ ), the phosphatization itself does not provide us with much information as to the conditions under which the beds were deposited, though one may presume with Andersson and Hedström that it happened within the shallow sea region (ANDERsson 1895, Hedström 1896). A number of the phosphorite nodules are undoubtedly strongly phosphatized calcareous mud, whereas others (pl. II, fig. 3) must rather be regarded as small lumps of excrement whose components are cemented together with calcite. Presumably the phosphorite precipitation itself was partly connected with the destruction of corneous-shelled organisms, especially Brachiopods, which lay washed together in small heaps on the sea bed and possibly were further concentrated by negative sedimentation.

The transitional bed between the zone with Paradoxides davidis and that with Paradoxides forchhammeri at the Læsaa must presumably be regarded either as a shelly bank or a high tide line, as at the Øleaa its place is occupied by a thin band of alum shale (see the discussion on the importance of the fossil concentration p. 43). As it contains elements of the fauna of both the Davidis Zone and the Forchhammeri Zone, the first group of these elements must presumably lie in secondary position or have been concentrated by negative sedimentation. Its content of quartz grains and glauconite, like the phosphorite deposit in the Davidis Zone, seems to have originated from broken-down Exsulans Limestone, and the much broken shell fragments may actually also be regarded as clastic elements, washed out from unhardened calcareous mud in the Davidis Zone elsewhere and transported in the form of sand grains. The presence of "cone-in-cone" structure would seem to indicate littoral conditions of sedimentation, and it is not impossible that the region actually was a beach. But, as will appear from the foregoing, there are several possible interpretations.

The Andrarum Limestone was considered by Grönwall to have been deposited in relatively low water under conditions similar to those prevailing during the deposition of the limestone bed of the 
Davidis Zone (GRöNwall 1902). Probably this is correct, but during this deposition no arenaceous material was transported from elsewhere, neither in the form of quartz grains, glauconite nor lime-sand.

With the commencement of the period with Lejopyge laevigata the supply of fine terrigenous mud again increases. GRönwalL believes that these shales were deposited in fairly deep water, and in this he is undoubtedly right. Here the calcareous lenses were presumably formed in the same manner as those in the lower alum shales, and they signify the border zone between calcareous mud facies and the terrigenous mud facies.

From this account of the development in the Bornholm Middle Cambrian it will be seen that continuous limestone beds here always occur in conjunction with conglomerates or sandy deposits, and under such circumstances that they must be regarded as littoral or neritic deposits, that is to say in shallow water and relatively near the coast, whereas the shales represent the deeper parts of the sea floor. This is quite in conformity with what is found elsewhere in the Scandinavian Cambrian, e. g. in Öland (see p. 63) and in Västergötland (see p. 65). The same transpires from a comparison between the series in Bornholm and in Scania, where it is much more complete and of greater thickness. There the shale facies definitely predominates over the limestone facies. However, there is one exception from this rule in the Andrarum Limestone, which in Scania too forms a continuous limestone bed, with no other sign of littoral sedimentation. The fact must therefore be borne in mind that the conditions for the formation of pure limestone deposits are really quite independent of the depth of the water, but in the first place is conditioned by the doposition of fine terrigenous material on the spot being very slight. This may be due either to the calcium carbonate having been deposited under such conditions that the fine terrigenous material was unable to precipitate, or to the land behind having been so low and having had so little relief that this, in conjunction with climatic conditions, has caused the supply of terrigenous material to the sea to be very small. As continuous limestone beds occur everywhere in Scandinavia in the zone with Paradoxides forchhammeri, the latter alternative seems to be the more acceptable for this zone.

\section{b. Upper Cambrian.}

In the Upper Cambrian part of the series the shale facies clearly predominates over the limestone facies. Continuous limestone beds occur at only two levels, viz. the zone with Olenus and that with 
Orusia lenticularis. The terrigenous components in the shale are much finer in the grain and play a more subordinate rôle in relation to the bituminous substance than in the Middle Cambrian alum shales.

The fauna is rather poorer than in Scania and, as everywhere in Scandinavia, is somewhat uniform in character, consisting as it does almost exclusively of Trilobites and Brachiopods. Whereas the Trilobites are represented by several genera the Brachiopod fauna consists of very few species. This apparent uniformity may of course be due to various causes.

It must be remembered first and foremost that the fossil content of a sediment provides only an incomplete picture of the original fauna, as for the most part it is organisms with shells or other hard parts that are preserved. Only exceptionally, such as in the famous Burgess shales at British Columbia, does one encounter well-preserved impressions of both worms and other organisms with no solid skeletal parts. There can scarcely be any doubt that both worms and algae formed an essential element among the organisms in the Cambrian Sea in Scandinavia, and that to a great extent the algae supplied the organic material whose decomposition aided in the formation of both sulphuretted hydrogen and calcium.

A curious explanation of the uniformity of the Cambrian fauna considered as a whole was earlier given by DALY $(1907,1910,1912)$. He considered that the water of the pre-Cambrian Sea was almost free of calcium, and that it was only in the Cambrian period that there was just sufficient dissolved calcium carbonate in the sea water for the Trilobites to form a calcareous-kitin armour and the Brachiopods a shell of phosphate of lime. It was not until Ordovician times that the calcium content in the sea water became so high that purely calcareous-shelled organisms were enabled to appear. Sometimes DALY's theories seem rather fanciful, and he has apparently overlooked the fact that in both pre-Cambrian and Cambrian times in North America there are large reefs of calcareous algae and coral-like organisms such as Archaeocyatus (Walcott 1914, 1916, Schuchert \& Dunbar 1933, 1934). On the other hand, as was stated on page 33 both PIA and CLARKE, from quite different presuppositions, maintain that the salinity of the sea water in Palaeozoic times was different to what it is today.

It might very well be, however, that the monotony of the fauna was primary and due to oecological causes. Examples from present-day seas show that in regions with a low oxygen content, for instance Phaseolina mud in the Black Sea, where furthermore the sulphuretted hydrogen is beginning to assert itself, one finds a rather monotonous fauna but one that is particularly rich in individuals and consisting 
of forms that are more resistant to the low oxygen pressure and the toxic effects of the sulphuretted hydrogen. As the competition for food with other species is therefore quite minimal under these conditions, these hardy forms occur in countless numbers of individuals, whereas in other places they are forced well into the background.

Another peculiarity of the Upper Cambrian fauna is that the fossils, much more than in the Middle Cambrian, occur concentrated in thin horizons separated by thicker beds of almost unfossiliferous shale.

The meaning of these fossil concentrations and pronounced stratigraphical zones has been much discussed, especially during the past decade, and several different theories have been presented. Originally there was it seems an inclination to see in this a sign that there had been repeated mass-extinction of the whole fauna as a result of poisoning, followed by new immigrations. We know from Walvis Bay on the west coast of . South Africa of such mass-extinction and total destruction of all animal life (Classen 1930, Kaiser 1930). From the Norwegian fjords Münster Strøm states that the phenomenon sometimes occurs when salt water from the sea flows in over the threshold and down along the bottom, whereby the fresher water there, containing sulphuretted hydrogen, is lifted up (STRøм 1936). These mass extinctions also take place periodically in the Kara-boghaz Gulf in the Caspian. As regards the Hunsrück Shales GürICH explains the fossil concentration and zone formation by the theory that the water as a whole was poor in oxygen and rich in sulphuretted hydrogen, and that the organisms developed on the border of the possibility of animal life on the whole. Periodically the formation of sulphuretted hydrogen becomes predominant, whereby all fauna is destroyed. This state continues for some time; but if uplifts occur, or through other causes fresh water gets down to the bottom, a new fauna may immigrate and live for some time until stagnation again gets the upper hand (GürICH 1931). Against this view Richter (1931) objects that such a mass-extinction would affect both adults and young animals, whereas in the fossil concentrations of the Hunsrück shale there are fully grown animals only. In Bornholm's Upper Cambrian, however, one often encounters Trilobites in the young stages (Poulsen $1923^{\prime}$, so that RichteR's objection does not apply there.

We find a somewhat similar view expressed by ULRICH (1911). On the other hand Weigelt (1923) gives another explanation. In the low fen cliffs of Amrum there are also thinly bedded accumulations of shells separated by beds of unstratified shell-less clay. The fauna in the various shell horizons is often very monotonous and often consists of a single species. It is a fact, however, that all individuals in the 
same stratum are more or less of the same order of size. In the shallow waters below these cliffs he now finds shells of the same forms as those forming the shelly strata in the cliff, lying distributed in zones parallel with the coast and also in such a manner that the different zones contain very few species, but with all individuals of about the same order of size within the zone. This phenomenon is due to the sorting action of tidal streams. Through the medium of the continuous alluvion the various zones are thrust in over one another, thus giving rise to the strata in the sections. On the background of conditions in the North Sea Weigelt examines the conditions under which durable fossil deposits can be formed, and comes to the conclusion that they are favourable to seaward of the shallow water region proper and also to landward as a result of alluvion. Between these two belts we find built up fossil-free, or rather fossil-poor, sediments. If this area distribution is projected in time, we shall, as a consequence of the constant displacement of the various zones on the sea floor, see them lying vertically one over the other in the sections.

Working from WeIGELT's theories WASMUND points out that when in a section a bed of fossils with large specimens is followed by another with small specimens of the same species, this does not necessarily mean that such changes have taken place in environmental conditions that dwarf forms are now produced, as we are not concerned here with two societies of living animals (Biocoenose) but of two societies of dead animals (Thanatocoenose), and this separation into large specimens in the one horizon and small ones in the next may simply be due to a mechanical sorting of the dead organisms according to size. If in the same manner in a series of sediments we find a constantly alternating fossil content, this will not always mean that there has been an extinction of an older fauna and an immigration of a younger one, as it may be the result of a simple working up and assortment of dead material (WASMUnd 1926). Jessen (1932, a, b) also treats the same phenomena according to the same principle.

After studying the Lias sediments in Germany Frebold $(1925,1927)$ arrives at the conclusion that the fossil concentrations form the termination of a sedimentation cycle and that they were formed at the close of an uplift period, or rather immediately prior to the beginning of a new sinking (special undation in STILLE's terminology). Later Frebold combines these conclusions with Weigelt's theory for the interpretation of the fossil concentrations in the ScandinavianBaltic Cambro-Silurian, mainly on the basis of erratic boulders in North Germany. He points out at once that in these sediments there are two types of fossil concentrations. In one the entire block is full 
of the heads or pygidae of a single form, whereas other parts of the armour are lacking. As examples he mentions stinkstone with Agnostis pisiformis, stinkstone with Peltura scarabaeoides and stinkstone with Orusia lenticularis. The other type is represented by Tessini Sandstone from Öland. In this case only the surface is covered with remains of Trilobites; but in contrast to the former type, besides head and pygidium we find other parts of the armour, but mainly as fragments of every possible size. Mention is also made of transitional forms between the two types, especially those which, in addition to Agnostus pisiformis, contain Olenus truncatus, and others which, in addition to Peltura scarabaeoides, contain Sphaerophthalmus alatus, and boulders with both Orusia lenticularis and Parabolina spinulosa.

Frebold now holds that such fossil concentrations are always formed under the influence of forces which move the bottom layers of the water. The fauna alternation may either be purely mechanically conditioned or be due to a decrease of the water depth and changes in the conditions of life connected with such decreases, here too in conjunction with a mechanical sorting of the dead animals. He also believes that the Scandinavian concentrations of Trilobites were formed in shallow water. As both Agnostus and Peltura, besides in the special strata where they are strongly concentrated, also occur in the underlying parts of the series — but there in conjunction with other forms and, like the other faunistic components, more sporadically - he assumes that at any rate there is a possibility that in those strata where they occur in immense numbers there prevailed conditions of life particularly favourable to one species, which was thus enabled to spread at the expense of the others. In this he sees a sign that there were changes in the water depth from deeper to more shallow. However, as both Agnostus pisiformis and Peltura scarabaeoides disappear in the strata overlying the fossil concentrations, FrEBoLd is now after all inclined to believe that it was rather a question of a mass-extinction than of a mechanical sorting of dead animals.

Frebold's demonstration of the fact that there are several types of fossil concentrations is important, in that it shows that we must be cautious about generalizing too far, and that it is necessary to treat the various parts of the series separately.

As was stated above, fossil concentrations are not particularly pronounced in the Bornholm Middle Cambrian; only in the transitional stratum between the zone with Paradoxides davidis and Par. forchhammeri does one occur, and this is described above p. 40. In it are shell fragments of every possible size, and there has never been any mechanical sorting. In the lower alum shales the fossil content is 
somewhat higher in the calcareous lenses than in the shales. The same thing has been observed elsewhere, and the view has sometimes been expressed that the poverty of the shales in respect of fossils is due to the fact that they preserve better in the limestone; however, examples in Bornholm and also in Swedish localities show that in some places the shales are extremely rich in fossils, and that from the shales the fossil horizons continue in through the calcareous lenses, at both places in the form of very thin bands with the same fossil frequence. The presumption is rather to be assumed that if sometimes the calcareous lenses are more fossiliferous than the surrounding shale, it is a primary character that may either be due to their representing patches on the bottom of the sea where life conditions have been favourable, e. g. in the form of more favourable supplies of nutritives, or that there have been local accumulations of dead shells through the action of the water.

In the Upper Cambrian, fossil concentrations separated by unfossiliferous shale are much more pronounced, as already stated. In the zone with Agnostus pisiformis, in that with Olenus and that with Homagnostus obesus all the specimens are fairly whole and more or less of the same size. In each of the two Agnostus levels there is only one species, whereas in the Olenus Zone one finds several species together. On comparing the development of the Olenus Zone in Bornholm with that at Andrarum in Scania we observe an interesting difference. At Andrarum the zone has a thickness of $10 \mathrm{~m}$, and the various species af Olenus occur each at its own level, whereas in Bornholm they lie all together in a single thin band. This merely shows of course that sedimentation was slower in Bornholm than in Scania; there is no reason for taking it to be a sign of mass-extinction or the sorting action of tidal streams.

There is another noteworthy difference in the vertical distribution of Homagnostus obesus in Bornholm and at Andrarum such as we see it in the two sections in Stora Brottet (WESTERGARD 1922).

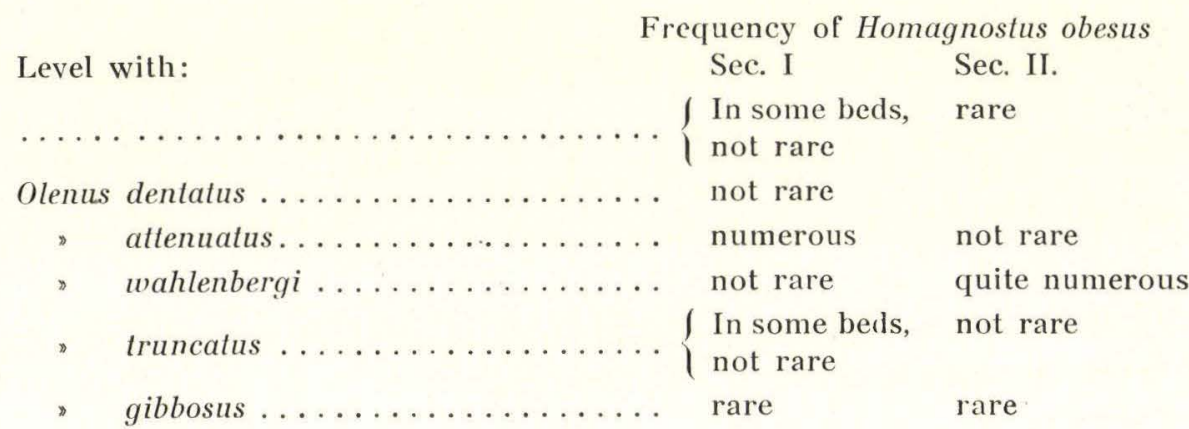


Homagnostus obesus is also traceable at a still higher level, as near Andrarum it was found in erratics together with Protopeltura aciculata.

Thus we see that at Andrarum Homagnostus obesus begins faintly to appear in the lower part of the Olenus Zone; it attains to its maximum and numerically greatest development somewhat higher up, whereupon it disappears very gradually. In Bornholm, on the other hand, it occurs only at one particular level, one that lies slightly above the Olenus level. This of course is capable of several explanations. It might simply be that the shales are so crowded with Olenus fragments that the Agnostus fragments are wholly concealed by them; but as these strata were very thoroughly examined by Poulsen this explanation will hardly do. Next it might be imagined that the stagnation in the deepest parts of the marine region, that is to say in Scania, had become so intense that all animal life became impossible out there, for which reason the fauna moved to shallower water. When conditions again improved Homagnostus obesus moved out again to the deeper water in the period covering Parabolina and Orusia. But as over the upper occurrence of Agnostus at Andrarum we find shale with Olenus scanicus, which is missing in Bornholm, this explanation does not seem very probable either. Then there is a third possibility, viz. that there was a mechanical sorting of dead animals by tidal streams, in such a manner that forms living side by side at Andrarum, in Bornholm lay at two separate levels according to the Weigelt principle. As this sorting means that the smaller specimens lie to landward and the larger to seaward, a negative change of level would cause the smaller forms in a section to lie above the larger ones. This is just what is the case in Bornholm with Olenus and Agnostus, so that this distribution would suggest that there had been a regressive movement of the sea in the Olenus period. This also agrees well with the fact that the two youngest forms af Olenus, Olenus attenuatus and Olenus scanicus, are unknown in Bornholm, and that also in other parts of the border zone of the sedimentation region (Västergötland, Östergötland and Öland) there are signs of negative displacements of the coast just in this period; and finally, in the Olenus Zone in Bornholm there are continuous limestone beds, whereas in Scania there are some flat calcareous lenses, a sign which, compared with the distribution between limestone facies and shale facies in the Bornholm Middle Cambrian, also indicates fairly neritic sedimentation. $\left.{ }^{1}\right)$

$\left.{ }^{1}\right)$ It should be remarked here that an examination of WEsTERGARD's sections shows that the above instance is the only one to which Weigelt's explanation has been found to apply. 
In its middle region the zone with Orusia lenticularis contains a continuous limestone bed with "cone-in-cone" structures and a very monotonous fauna consisting almost exclusively of Orusia lenticularis, whereas Parabolina spinulosa occurs only very rarely at the Lasaa and not at all at the Øleaa.

As was stated when dealing with the Middle Cambrian sediments, the limestone bed and the "cone-in-cone" structure suggest littoral conditions of deposition, but the monotonous fauna seems difficult to explain by this alone, as the Orusia Zone of both Västergötland and Öland is partly conglomeratic and was laid down under littoral conditions, but at the same time contains a Trilobite fauna that is somewhat richer in species. The circumstance that Bornholm's Orusia Zone consists almost entirely of a single Brachiopod species almost seems to indicate that in this period there prevailed special oecological conditions which were unfavourable to the Trilobites, whereby Orusia, having thus no competitor for their food, were enabled to propagate in such immense numbers.

There does not seem much reason to suppose that the stagnation and the content of sulphuretted hydrogen were much more pronounced in Bornholm than in Scania, whereas it is imaginable that the salinity was particularly high. If the limestone bed in the Bornholm Orusia Zone was deposited in a shallow lagoon with a narrow and shallow affluent which at times was perhaps entirely blocked, the salinity of the lagoon would very soon alter both in concentration and composition, in which case unfavourable conditions for the Trilobites might be created. As was mentioned in an earlier work (KAJ HANSEN 1938), "cone-in-cone" structure might possibly be due to the influence of sulphates on the shape of the calcite crystal, and in a lagoon of this kind the sulphate content may very easily become higher than in the open sea. Calcium precipitation would also be promoted by an increase of the sulphate concentration. Further support for this view lies in the fact that the limestone bed itself contains no small quantity of bariie (Locality VI), and in the overlying shales small crystals of both gypsum and barite are exceedingly numerous (CALLISEN 1914). The barite lenses are probably genuine concretions formed by the precipitation of solutions containing barium. It is true that barium sulphate is slowly soluble in pure water, but in even very weak saline solutions its solubility increases and soon reaches the same order as calcite (TrEnER 1908), and thus the barium in solution is able to permeate the sediment after deposition. Nevertheless, we also know of barite concretions formed on the sea floor (Jones 1883, BøgGILD 1916). 
In the zone with Eurycare and Leptoplastus and in the lower subzone of the Peltura Zone a shale facies again predominates and limestone occurs in the form of rows of stinkstone lenses. Here the fossils are concentrated in very thin bands separated by unfossiliferous shale; but there is no indication of a mechanical sorting according to the Weigelt principle.

The calcareous lenses contain more sulphidic and organic material than the limestone at any other level (see table p. 36), but nevertheless consist of an almost normal crystal mosaic, of which the individual crystals are interspersed by thin winding smears of the black mud. In these calcareous lenses there are no sub-angular sand-like crystals such as those found in the limestone bed of the Davidis Zone. This further seems to confirm the assumption that the sand grains in the Davidis Zone must be regarded as lime-sand, and that they did not acquire their abnormal development on account of the impurification of the calcareous mud with black organic and sulphidic material. Faintly developed "cone-in-cone" structures are sometimes seen in the calcareous lenses, but the crystals are very small and they have no common orientation. As moreover the calcareous lenses contain barite crystals, and as both gypsum and barite also occur in the surrounding shales, it is possible that these "micro cone-in-cone" structures may be associated with the influence of sulphates on the shape of the calcite crystals.

As to the origin of the calcareous lenses themselves, the same may presumably be said about them as about the calcareous lenses in the Middle Cambrian. There is nothing here at all to suggest subsequent concretions formed after the deposition of the shales. In places the transition between shales and calcareous lenses is almost insensible, and the shales present no trace whatever of pressure or other disturbance as a consequense of pressure during the growth of the concretion. Furthermore, these calcareous lenses are quite devoid of the coarsely crystalline, sometimes stemmy marginal zone that otherwise is fairly common. The fossil horizons continue from the shales right through the calcareous lenses, with the same fossil frequency, and there is no indication whatever that the lenses represent separate accumulations of shell fragments which might be imagined as being the starting point of the accretion. Correns (1923) discusses the origin of very similar calcareous lenses in the Middle Devonian Odershäuser limestone in the Rhenish shale mountains, and arrives at the conclusion that these lenses must have originated primarily on the spot in the form of calcite concretions and at the same time as the deposition of 
the surrounding shales. This, CorRens thinks, may take place in two ways: 1) as a kind of embryonic reef-building from growths of algae or corals. The original structure would then disappear through recrystallizations. Level changes, e. g. in the form of increased supplies of mud, stopped the growth of the reefs before they had attained any great development. 2) Local accumulations of dead organisms on the sea bottom brought about a more intense local calcium precipitation in association with the processes of decomposition, possibly with the aid of bacteria. The latter possibility comes very close to what was said on p. 39 and seems well applicable to the origin of the calcareous lenses in the Bornholm alum shales. Correns also advises that if we are to understand a sediment properly, we should as far as possible reconstruct the geographic constellations for the period when the sediment was formed and for both before and after - a claim that is also made by PompeckJ (1914). Correns now shows how the Devonian Odershäuser limestone was in fact formed in the border zone between shale facies and limestone facies from southeast to northwest.

If we compare this with conditions in the Scandinavian Cambrian we see that everywhere in the border regions (Öland, Västergötland) where we have shallow-water sediments we find continuous limestone beds in association with them, i. e. distinct limestone facies, whereas in the central parts of the sedimentation regions (Scania, Oslo area) it is shale facies that dominate, and the same is the case in the border regions where there are deeper water sediments. In these border regions, however, the shale facies contain many large calcareous lenses, lying more or less close together, whereas in the central regions of the sedimentation basin, for instance Scania, the lenses are much smaller and are more scattered. Accordingly, the sediments over the zone with Orusia lenticularis were laid down during a regression period which lasted more or less without change right into the Ordovician. 


\section{Chapter IV.}

\section{Palaeogeography.}

In an earlier publication (KAJ HANSEN 1937) an account was given of the palaeogeographical conditions in South Scandinavia and the Baltic as far as the Lower Cambrian period is concerned. As the changes in the distribution between sea and land during the whole of that period were considerable, it was necessary to make a series of maps showing the progress of developments. In Middle and Upper Cambrian the palaeogeographic conditions are much more siable, and the changes as a whole were more of local and peripheral nature, so that one map can be employed as expressing the state of affairs within a long period. It will be natural to consider the Middle Cambrian and the Upper Cambrian periods separately.

\section{a. Middle Cambrian.}

In Scandinavia the complete development of the Middle Cambrian series comprises the following zones:

The zone with Lejopyge laevigata.

$\begin{array}{ll}» & \text { Paradoxides forchhammeri. } \\ » & \text { Paradoxides davidis. } \\ » & \text { Liostracus linnarssoni. } \\ » & \text { Ctenocephalus exsulans. } \\ » & \text { Paradoxides ölandicus. }\end{array} \quad\{$ Tessini Zone.

In B o r n holm the zone with Paradoxides ölandicus seems to be missing and we have on the whole shallow-water and neritic sediments right up to and including the zone with Paradoxides forchhammeri. Several of the horizons contain conglomerates and are of a character that is almost littoral.

In $\mathrm{S}$ c a n i a the series is much thicker and more complete, and it contains no true littoral sediments. The Ölandicus Zone is represented 
by a fragment limestone which still contains a few quartz grains and grains of glauconite. It is recorded in almost homogeneous development at Andrarum, Brantevik and Kiviks Esperöd. At the two latter localities the Exsulans Limestone forms a continuous limestone bed, and the same is the case at Sandby in the Fågelsång district. Tullberg (1882) writes that at Andrarum it forms a bed of not fully coherent stinkstone. At all localities the rock is a lighter or darker grey, sometimes quite black limestone, so that it differs very considerably from the pale, glauconitic Exsulans Limestone in Bornholm. In Scania it was apparently deposited in deeper water and farther from the shore than in Bornholm.

At Andrarum the zone with Liostracus linnarssoni is divided into several sub-zones, all consisting of alum shale with sporadic stinkstone lenses (Tullberg 1880, 1882, Linnarsson $1882 \mathrm{a}$ ).

The alum shale with stinkstone in Savværksbækken is placed by Moberg $(1910)$ to the zone with Par. davidis.

As in Bornholm the zone with Par. forchhammeri is developed in the form of Andrarum Limestone, but with a thickness of $1.2 \mathrm{~m}$ at Sandby, $0.9 \mathrm{~m}$ at Andrarum, and $0.8 \mathrm{~m}$ at Gislövhammer (WESTERGÅRD 1942), i. e. almost twice the thickness of the Bornholm Andrarum Limestone.

The Lejopyge Zone is mainly developed as alum shale with stinkstone lenses, as in Bornholm.

Thus throughout the whole of the period that is represented by the Middle Cambrian series the sediments in Scania on the whole are of the type laid down farther from the shore, whereas in Bornholm they were deposited nearer - indeed in certain horizons apparently in - the littoral zone itself. Accordingly, the land area from which the terrigenous components of the sediments came must have been nearer at Bornholm than at Scania, presumably south or southwest of Bornholm.

In Ö $\mathrm{l}$ a n d the development of the Middle Cambrian differs markedly from what is to be seen in the rest of Scandinavia. The Ölandicus Zone consists of a greyish-green argillaceous shale, here and there with large greyish-green calcareous lenses. Upwards the zone concludes with a conglomerate, the Acrothele granulata conglomerate with stones of rocks from the Ölandicus Zone (Hedström \& Wiman 1906, WesterGÅRD 1929). HADDING says that the rocks of the Ölandicus Zone must have been deposited in calm water, where neither breakers nor tidal streams disturbed their sedimentation (HADDING 1927). It must have proceeded in shallow water outside the littoral zone on a very flat sea floor in an inland sea. WESTERGÅRD (1929) says that compared 
with developments in Jämteland, the development of the Ölandicus Zone in Öland is incomplete, as the upper sub-zone is missing.

Farthest south at Risinge the zone with Ctenocephalus exsulans is developed in the form of a dark, sandy fragment limestone (MunTHE 1902), whereas more to the north it lies in the lower part of the Tessini Sandstone. We thus see that already here differences begin to appear between developments in North and South Öland, and these differences become more and more pronounced the higher we go up the series.

The zone with Liostracus linnarssoni is developed as a sandstone, Tessini Sandstone, which to the south is bituminous and at some places resembles alum shale (Hedström \& Wiman 1906). More to the north it is a pale, glauconitic sandstone which upwards becomes more and more calcareous. The sandstone thins off to the north and seems to be missing north of Äleklint. Hadding considers it to have been deposited in calm water which has permitted the sedimentation of even the finest material. Nevertheless its glauconite content shows that it must have been deposited in the open sea and not in lagoons (HADDING 1929).

The zone with Par. davidis is faintly developed. Only very few of its fossils are known, some from the upper part of the Tessini sandstone and others from the overlying Exporrecta Conglomerate.

Farthest south the zone with Par. forchhammeri is developed as an Exporrecta Conglomerate at the upper edge of a limestone bed. More to the north this conglomerate comprises not only this zone but also several of those overlying it, right up into Upper Cambrian.

Thus we see that gradually as we get higher up the series in Öland we encounter indications that the coast was moving nearer, and that at the close of the Middle Cambrian period North Öland at any rate lay very close to a shore, perhaps even emerged at times.

Cambrian sediments in Gotland are known only from the two borings. In the Visby boring we find merely the zone with Par. ölandicus and parts of the Tessini Zone. The whole series is developed as bluish-grey shale with a thickness of $36.6 \mathrm{~m}$. Over it lies Ordovician limestone (Hedström 1923). In the File Haidar boring the thickness is $31.4 \mathrm{~m}$. The rocks in the Ölandicus Zone are more arenaceous than in Öland and limestone is more rare. Uppermost is a greyish-white sandstone which presumably represents parts of the Tessini Zone (ThORSLUnd \& Westergånd 1938).

Both in Estonia and in the northern Baltic region the Middle Cambrian is missing. 
In $\mathrm{N}$ ä $\mathrm{rke}$ the Middle Cambrian is known chiefly from borings. The lower part of the Ölandicus Zone is a greyish-green, in part calcareous sandstone with glauconite and phosphorite in small quantities. Upwards this passes into dark greyish-green, argillaceous glauconitic sandstone, over which are dark grey glauconitic shales with scattered quartz grains, and uppermost a pale, greyish-green soft shale with sporadic thin bands of light green, micaceous sandstone and occasional thin lenses of greyish-green, argillaceous limestone. The border against the next zone is marked by a band $1 \mathrm{~cm}$ thick containing quartz grains from 1 to $4 \mathrm{~mm}$. At Bredsäter the thickness of the zone is $11: 95 \mathrm{~m}$.

The Tessini Zone presents a picture similar to that of the Ölandicus Zone. Only the lower sub-zone with Triplagnostus gibbus is developed. The thickness decreases from west to east and at Bredsäter is $0.9 \mathrm{~m}$, at Vrana $0.87 \mathrm{~m}$ and at Tångsäter $0.73 \mathrm{~m}$. It is thus evident that during the greater part of the Paradoxides paradoxissimus period Närke lay above the sea level, and the area emerged earlier than the East and West Göta plains.

In the western part of the area the Forchhammeri Zone is developed as an Exporrecta Conglomerate which at Bredsäter has a thickness of $0.07 \mathrm{~m}$. In this area the conglomerate contains a fairly considerable number of quartz grains, which indicates that a pre-Cambrian rock surface lay exposed above the sea in the west or northwest. At Latorp the conglomerate contains numerous Upper Cambrian fossils.

At Vrana the zone consists of $0.96 \mathrm{~m}$ of alum shale, and at Tångsäter of $0.73 \mathrm{~m}$ of the same. In this period Närke lay just below the surface of the sea, exposed to alternating sedimentation and erosion. At a few places the zone is missing.

The zone with Lejopyge laevigata at Vrana is developed in the form of a limestone bed, at Tångsäter as alum shale (Linnarsson 1875, ANDERSSON 1893, WestergåRD 1922, 1940).

Östergötland. Here the Middle Cambrian is known from borings and from erratics. The Ölandicus Zone begins with a sandstone conglomerate containing phosphorite, sharply delimited from the underlying Lower Cambrian sandstone conglomerate. The lower half consists of greyish-green, glauconitic sandstone and shale, the upper half of grey argillaceous shale with interbedded thin bands of slightly bituminous alum shale. (At Tornby the thickness is $6.45 \mathrm{~m}$ ).

The lower part of the Tessini Zone is developed as an only slightly bituminous alum shale, the middle and upper parts as a grey, rather dark and often greenish argillaceous shale with limestone lenses of the colour of the shale. 
In the Paradoxides davidis period Östergötland lay above the sea surface. At Tornby the thickness of the Tessini Zone is $11.8 \mathrm{~m}$.

The Forchhammeri Zone begins with a thin band, frequently argillaceous, of phosphoritic and sometimes glauconitic lime sandstone, at Borgham having a conglomeratic structure. Over this is alum shale, only slightly bituminous, with occasional stinkstone lenses. The basal deposit and the overlying sandstone presumably correspond to the Exporrecta Conglomerate in Västergötland. The greater part of the alum shale is placed to the zone with Lejopyge laevigata. The thickness decreases from east to west and at Borgham measures $2 \mathrm{~m}$, at Skåningtorp $4.8 \mathrm{~m}$ and at Tornby $5.35 \mathrm{~m}$. (Linnarsson $1882 \mathrm{~b}$, Tullberg 1882, Magnusson 1922, Westergård \& Munthe 1928, WesterGÅRD 1930, 1940).

In $V$ ästergötland there is at the boundary between Lower and Middle Cambrian a conglomerate, in which the pebbles at Kinnekulle, Billingen and at Falbygden are of the same nature as the underlying part of the Cambrian sandstone and were formed by the breaking down of that sandstone (Holm \& Munthe 1901, Wallerius 1928, Westergård \& Munthe 1928, 1931). The conglomerate also occurs at Halle and Hunneberg, but there it differs petrographically quite a lot, apart from the more easterly occurrences (KAJ HANSEN 1933), as some of the components seem as if they could not have originated from the underlying sandstone, but direct from the pre-Cambrian; they thus suggest that out here towards the west there must have been pre-Cambrian areas exposed above the surface of the sea. Directly overlying the conglomerate are glauconitic sandstone and shales, and over them alum shales containing stinkstones. WESTERGARD assumes that the zone with Par. ölandicus is missing at any rate at Nordbillingen and Kinnekulle, and that in early Middle Cambrian times these areas lay above the sea (Westergånd 1931). The zone with Par. davidis occurs at Hunneberg (WALlerius 1930) but is undeveloped and is missing in the more easterly and particularly the more northerly localities. The zone with Par. forch hammeri is developed as an Exporrecta Conglomerate which, at the north end of Billingen, lies at the upper edge of a limestone bed of which the deeper parts contain a fauna that belongs to the zone with Liostracus linnarssoni. WESTERGÅRD assumes that here too there is a lacuna in the series and that Västergötland in the period with Par. davidis lay above the surface of the sea (WESTERgÅnd 1931).

The zone with Lejopyge laevigata is everywhere developed as alum shale with stinkstone. The thickness is greatest to the south, $4 \mathrm{~m}$ in Falbygden and decreasing northwards, $3 \mathrm{~m}$ at Billingen and Kinnekulle (Munthe 1906). 
From the above it will be seen that throughout the entire Middle Cambrian period in Västergötland the sediments as a whole are fairly neritic, and that at any rate the northeasterly part of the region at times lay above, or anyhow very near to the surface of the sea. The assumption must then be that during the whole period there was a land area to the north or perhaps northwest, and that its coast at any rate twice was thrust forward to the northeasterly part af Västergötland.

The Oslo Area. Southernmost in the Langesund-Skien region the Cambrian series begins at the bottom with a sandstone whose age is subject to some doubt (VogT considers it to be Lower Cambrian (VogT 1924), whereas STRAND (1929) thinks it not entirely unlikely that parts of it at any rate may be the equivalent of the lower part of the Middle Cambrian). The thickness of the sandstone is greatest to the south and decreases rapidly northwards (BRøGGER 1884). Upwards it passes insensibly into fossiliferous alum shale, the oldest part of which must be placed to the zone with Liostracus linnarssoni.

At Slemmestad the series begins with a thin conglomerate which is overlain by a dark fossiliferous stinkstone. To judge from the fauna reported by STRAND in this locality, the zone with Ctenocephalus exsulans would seem to be comprised in the limestone, as at Andrarum and in Bornholm, and also at Mjøsen, Solenopleura parva has been found only in this zone.

At Krekling the development of the Middle Cambrian is something like that at Langesund-Skien; at the bottom we find $2 \mathrm{~m}$ of Greywache Shale, which is partly Lower Cambrian, and over it fossiliferous alum shale, the lower part of which belongs to the zone with Liostracus linnarssoni (BRøGGER 1878).

It would seem to appear from the above that on the west side of Oslo fjord the Cambrian transgression proceeded from southeast to northwest, or more correctly, that already in Cambrian times the present Oslo fjord had formed as a fjord-like elongated submergence region.

Farther north at Randsfjord and in Hennungbygden the conditions are somewhat different, as immediately overlying a basal conglomerate there is alum shale with stinkstone lenses of Middle Cambrian age. The zone with Par. olandicus, that with $P$. paradoxissimus and that with P. forchhammeri have all been found here (HoLtedahl 1911, 1923). Holtedahl writes that here the sea forced its way from north to south, and that the region farther south at Oslo was dry land well into Middle Cambrian times. At the south end of Mjøsen the Middle Cambrian alum shales rest in a thin, presumably Lower Cambrian 


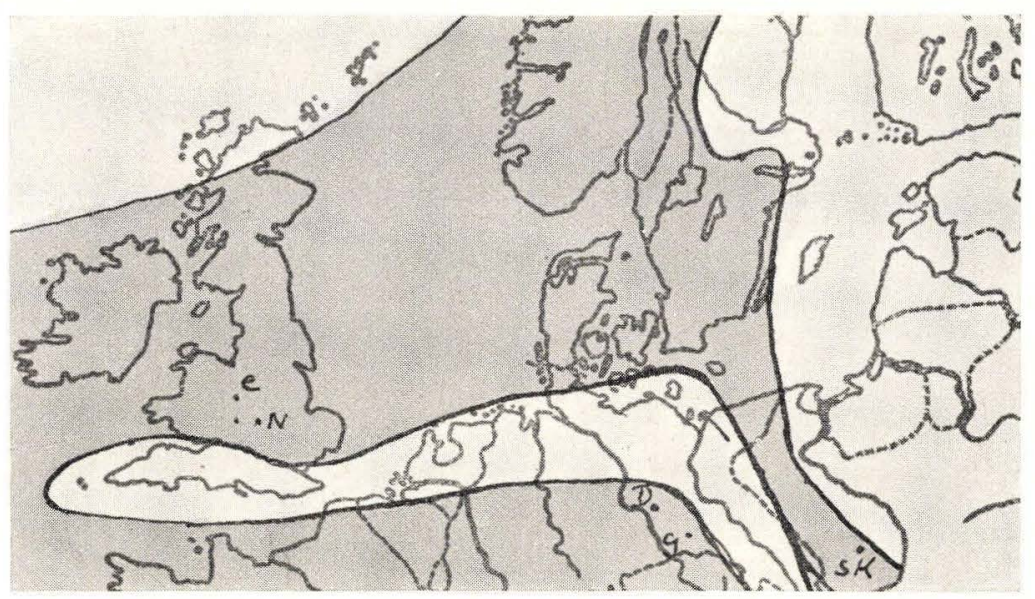

Fig. 13. Distribution of sea and land in the period with Paradoxides davidis. C. Comley, Gr. Britain. - N. Nuneaton, Gr. Britain. D. Dobrilugh, Germany. - G. Görlitz, Germany. SK. Swiety Kruytz, Poland.

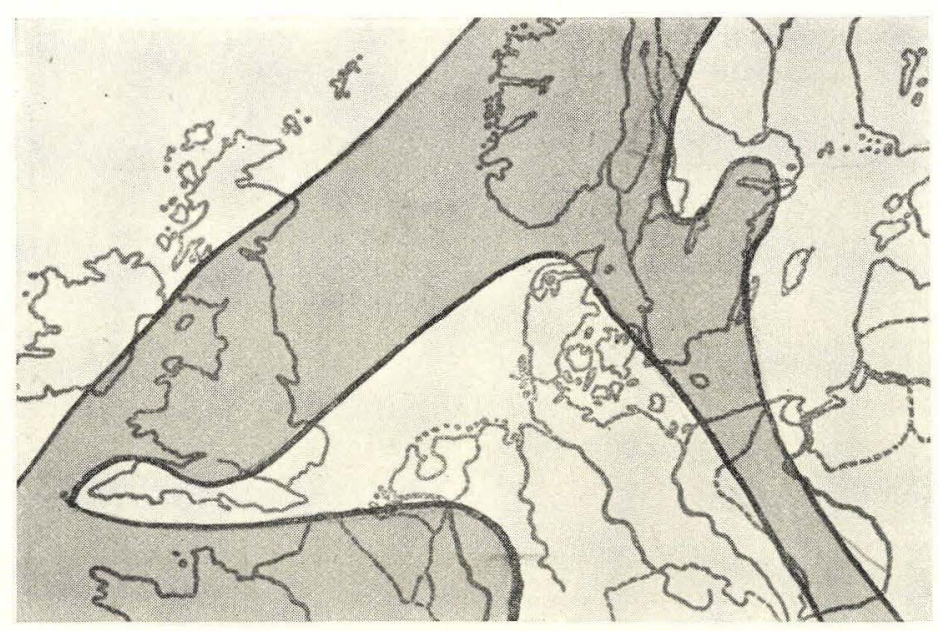

Fig. 14. Distribution of sea and land in the period with Paradoxides forchhammeri. 
conglomeratic basal stratum. Hitherto no fossil belonging to the Ölandicus Zone has been found here.

At the north end of Randsfjord Lower Cambrian shales lie directly over the pre-Cambrian, and they in turn are overlain by Middle Cambrian alum shale (Holtedahl 1915), and the same is the case both more to the east at Øksna and Kletten and to the west at Breidingen and Tonsaasen in Valdres. Farther north at Mjøsen, however, the Cambrian lies over the thick Sparagmite series. At the close of Lower Cambrian times the sea reached the central part of the Randsfjord area and to Finse in the northern part of the Hardanger plateau (Holtedahl \& BaIley 1938).

The picture thus arrived at of palaeogeographic conditions in Middle Cambrian times forms a natural continuation of what was earlier presented on the maps of the Lower Cambrian period (KAJ HansEN 1937). During the whole time we have a land area lying in the east part of the Scandinavia peninsula, its westerly shore having almost the same course as in Lower Cambrian times.

In the beginning of the Middle Cambrian period the northern sea (see fig. 13) extends southwards through the Oslo region, but it does not connect with the Baltic Sea moving up from the south until the period of the deposition of the zone with Liostracus linnarssoni. (See also STRAnD's map for the period with Ctenocephalus and Par. paradoxissimus the latter zone corresponding to what is here called the zone with Liostracus linnarssoni). The course of the other coasts of this land region can be determined only with great uncertainty. In Västergötland one encounters signs the whole time of a land area northwards which, at any rate in the period of Paradoxides forchhammeri, advanced over the northeasterly part of Västergötland. At Närke, too, there are traces throughout the Middle Cambrian period of a land area that must have lain to the north or northwest. In the South Baltic, too, there is land which, in the time after the deposition of the zone with Paradoxides ölandicus, reaches west about Gotland and somewhat later reacher the northern part of Öland. Finally, in Bornholm too we notice the presence of a land area which apparently lay to the south.

These circumstances indicate that in Middle Cambrian times South Scandinavia and the southern part of Balticum formed an inland sea, and the great similarity of the sediments combined with the also very strikingly uniform fauna all over the region points in the same direction. In order to determine the approximate boundaries of this sea, however, it is necessary to examine the most adjacent Cambrian sediments outside the Scandinavian-Baltic region. 
In the Britis h Is les we find Middle Cambrian sediments in the Midlands, and in Wales. The strata everywhere are much disturbed and full of faults, so that it is not always possible to obtain a complete cross-section through the series. In the Midlands we find the Cambrian at Comley, at Rushton and at Nuneaton. At Comley there are on the whole coarser sediments and numerous lacunae in the series, i. e. generally very neritic deposits (CobBold 1927). Somewhat more to the northeast at Rushton the series is complete and the sediments consist of alternating sandstone and shales which fairly well reflect the great fluctuations in the sedimentation that are more clearly visible at Comley. Still farther east at Nuneaton the sediments consist almost predominantly of shales (ILLING 1915). In these occurrences the fauna contains numerous forms that also occur in Scandinavia (CoBboLD 1911, 1913, 1920, 1927, 1931; CobBold \& Pocock 1934, Illing 1915). The sediments indicate that in the earliest section of the Middle Cambrian period a coastline must have run from a little west of Comley due south, and that this sea area formed part of the Scandinavian Baltic Sea (Fearnsides 1910). In South Wales the fauna at St. Davids in those zones that are earlier than the one with Liostracus linnarssoni in Scandinavia, i. e. the two lower divisions of the Solva series, include a fauna having a peculiar endemic character, as none of its forms is known from other British occurrences or from other European or even North American Middle Cambrian deposits. It is not until we come up to the upper part of the Solva series and in the Menevian that we find forms that are common to the other British occurrences and to Scandinavia. The sediments also alternate at St. Davids from sandstone in the earliest part of the Solva series through green to grey shales and then again to sandstone in the upper part of the Menevian, which corresponds to the zone with Paradoxides forchhammeri in Scandinavia (Pringle \& George 1937).

In Central Wales (Dolgelly Gold Belt, Merionethshire) the entire Middle Cambrian seems to be built up of fairly homogeneous grey and dark shales (ANDREw 1910, Jones 1933).

In North Wales we have at St. Tudval, Carnarvonshire, a development like that in South Wales, basally with sandstone with red and green shales, over it grey and black shales, and finally again calcareous sandstone with pebbles consisting of the rocks of the underlying zones. Here the series is less complete, as there is a lacuna corresponding to the zones with Paradoxides davidis and P. forchhammeri in Scandinavia (Nrcholas 1915). It is therefore presumable that here there was a coastline lying to the north or possibly the northwest. 
In $\mathrm{B}$ oh e mia the Cambrian transgression moved forward from southwest to northeast. At Skryje and Tyrovice the Cambrian is almost of littoral character and was deposited in a gulf (KeTtner 1923). The fauna contains numerous forms familiar from the Tessini Zone in Scandinavia and in the British Isles (РомрескJ 1895, Kettner 1923, Smetana 1919-1920, Chouff 1926). But already in the period with Paradoxides forchhammeri the sea withdrew again towards the southwest.

In P o l a n d the Middle Cambrian sediments at Swiety Kruytz consist of coarse sandstone with a rather poor fauna, though it contains a number of Scandinavian forms, but no Bohemian (BUBNoFf 1930).

In G e r m a n Middle Cambrian sediments have been found in the Bohemian border zone. At Görlitz in Silesia there is a greywache shale with a fauna in which Billingsella romingeri is the only one to be identified. This is a Bohemian form (Schwarzbach 1932). At Dobrilugh on the railway about midway between Berlin and Dresden a boring revealed a Middle Cambrian fauna with Paradoxides rugulosus in a hard quartzitic sandstone (PICARD 1928). In Frankenwald a Middle Cambrian fauna was found with close association to the Bohemian fauna. The sediments suggest a shallow sea not very far from a continent that lay towards the north and presumably divided the Bohemian-German sea from the Scandinavian-Polish sea (Wurm 1925, 1928). No trace of the zone with Paradoxides forchhammeri has been found in any of the German occurrences either.

These circumstances seem to show firstly, that the connection between the Scandinavian and the Polish seas, which existed at the time of Holmia kjerulfi (see KaJ Hansen 1937, figs. 7 and 8) and which later was interrupted, opened again in Middle Cambrian times, whereas the direct connection which existed between Poland and the British sea at the close of the Lower Cambrian period, was afterwards closed.

In the earliest section of the Middle Cambrian period a southern sea extended from the Mediterranean region and South France northeast up to Bohemia and the surrounding parts of Germany, but failed to get so far as to connect with the Polish sea. On the other hand it was presumably connected with the British sea and through it with Scandinavia. It is possible, however, that the earliest Middle Cambrian fauna in Poland belongs to the zone with Paradoxides davidis, that in the earlier periods there was a connection between Bohemia and Scandinavia eastwards, and that this connection did not close until the period with Paradoxides davidis. This means that the regression of the southern sea already began here, and only reached Bohemia 
in the period with Paradoxides forchhammeri. The connection between Bohemia and Southwest Europe is suggested by the fact that the fauna in the Middle Cambrian in Montagne noire (the French central plateau) belongs to the same fauna association as the Bohemian (WURM 1925 and 1928, Picard 1928, Bubnoff 1930, Schwarzbach 1932).

If we compare the maps Fig. 13 and 14 with earlier maps we find very good agreement on the whole, and the differences are of a relatively local nature. From HoltedaHL's 1919 map the above differs mainly in the fact that HoLTEDAHL does not reckon with a land area south of Bornholm. Born (1926) operates in the Middle Cambrian with a Jutlantic island stretching down into North Germany, and he writes that it prevents the free exchange of fauna between the Scandinavian and the Bohemian sea regions. However, the difference between the Bohemian and the Polish faunas is so great that BonN's island would have to extend much farther to the southeast to prevent an exchange of fauna between these two regions. Nevertheless, the principal difference between Born's and my maps really lies in the idea forming the basis of the two, for BonN, like most other authors who have previously attempted to unravel the palaeogeographic conditions, considers as sea everything that cannot definitely be reckoned as having been land, whereas I have adopted what is tantamount to the opposite principle, that of regarding as land everything that was not necessarily sea. Accordingly the two maps provide two opposed extremes for understanding the palaeogeography of these periods, i. e. the maximum and the minimum extent of sea and land in the time in question. On the other hand, Holtedahl's and Born's maps cover such wide periods of time that great changes in the distribution of sea and land took place within them. This was already recognized by FrEBoLd, for which reason he endeavoured to pick out the conditions within the various sub-divisions of the period (FREBOLD 1928) and drew maps of the time with Paradoxides paradoxissimus (which here spans from the zone with Par. olandicus to the zone with Par. davidis, both inclusive) and of the time with Paradoxides forchhammeri.

Frebold makes use of the maps of Holtedahl and Born as a basis but points out that certain regions, such as Västergötland and Öland, at times formed threshold regions and lay very near to, or sometimes even over the surface of the sea. Accordingly he assumes that in the Tessini period Västergötland formed an island, and that the northern part of Öland in the period with Par. forchhammeri formed part of the easterly mainland. This latter agrees completely with my opinion, whereas various objections may be raised against the former point. Frebold motivated his theory by saying that the 
thickness of the Tessini section at Kinnekullen is only a few centimetres; but this is erroneous, as HoLm \& Munthe (1901) report the thickness to be some decimetres. At the north end of Billingen the thickness is $6.5 \mathrm{~m}$. (WESTERGARD 1931), and something of the kind applies to the more southerly parts of the region (WESTERGARD 1928). Next, Frebold says that the Exporrecta Congiomerate in the zone with Par. forchhammeri has such a general distribution that it cannot be regarded as a neritic sediment, but rather as one with a general lowest water level. This however is not correct either, for the Exporrecta Conglomerate is characteristic of the Scandinavian sedimentation region's border zones Västergötland, Närke and Öland, whereas it does not occur in Östergötland and the more central parts of the sedimentation region such as Scania and the Oslo area. We know of analogous conditions in mountain ranges, for example the Tåssjöberg in Ångermanland, where the autochthonous Cambrian has the Forchhammeri Zone developed as an Exporrecta Conglomerate as in east Jämtland, and the allochthonous Skolle which is thrust from the west has the zone developed in the form of a $4 \mathrm{~m}$ alum shale bed with stinkstone (Asklund \& Thorslund 1934). Consequently, the period in the Middle Cambrian when Västergötland lay above the sea must be placed to the close of the period with Paradoxides davidis and the beginning of the time with Paradoxides forchhammeri, which agrees with Westergånd's opinion (1931). On the other hand, Frebold may. possibly be right in considering the region as forming an island; but he seems to have overlooked the fact that no Cambrian sediments have been found in the Siljan area in Dalecarlia; and if developments are followed step by step at any rate a part of the land which VOGT was the first to show had existed during Lower Cambrian times.

STRAND's 1929 map is the one that most closely approaches the present writer's views. It is perhaps a debatable point whether Småland in the earliest part of Middle Cambrian times lay above the sea. Actually there is nothing in the sediments of either Scania or Öland to argue that it did, as it is quite imaginable that the Öland Tessini Sandstone received its material from the east. On the other hand nothing positive can be adduced to disprove STRAnD's contention. Finally, Bubnoff in 1930 published a map, though this one seems to build exclusively on HOLTEDAHL's and BoRN's publications. 


\section{b. Upper Cambrian.}

The complete development of the Upper Cambrian comprises the following zones.

6. Zone with Acerocare.

5. » 》 Peltura and Sphaerophthalmus.

d. Sub-zone with Parabolina longicornis.

c. " " Peltura scarabaeoides.

b. » » » $\quad$ acutidens and Pelt.

minor.

a. » $\quad$ Ctenopyge flagellifera and Protopeltura

praecursor.

4. Zone with Eurycare and Leptoplastus.

3. » » Parabolina spinulosa and Orusia lenticularis.

2. " $"$ Olenus.

1. » $»$ Agnostus pisiformis.

In B or n o l m shale facies dominate over limestone facies. Continuous limestone beds occur almost exclusively in the Olenus Zone and the Orusia Zone, and no conglomerates are known. Possibly the Orusia Zone may be assumed to have been deposited in shallow water close to, or inside, the littoral zone or in a lagoon. Of the Acerocare Zone we know the lower sub-zone only, but on the other hand there is no sign of any interruption of the sedimentation above it. The Bornholm Upper Cambrian shales were apparently deposited in somewhat deeper water and at a somewhat greater distance from the shore than the Middle Cambrian.

In $\mathrm{S} \mathrm{c}$ a nia the character of the series as a neritic and deeper water facies is still more prominent. Nowhere in the section is there a sign of lacunae or other indication of neritic sedimentation. Here the series is more completely developed and has a greater thickness than at any other locality in Scandinavia, with perhaps the sole exception of the Oslo area. The thickness at Skarpsmölla (Röstånga) is $33.2 \mathrm{~m}$, at Sandby $55.8 \mathrm{~m}$, at Andrarum $36.1 \mathrm{~m}$, and at Gislövhammer $42.3 \mathrm{~m}$ (WESTERGÅRD 1942).

In Öland the Upper Cambrian reaches its full development farthest south at Degerham, where it occurs in the form of alum shale and stinkstone lenses. Continuous limestone beds occur in the Olenus, Orusia and Eurycare Zones. The Peltura Zone contains numerous flat calcareous lenses lying close together, and in the Acerocare Zone they lie so crowded together that they form almost a coherent bed. 
Farther to the north the series becomes more and more incomplete as one goes northwards. The Eurycare Zone disappears first and the Orusia Zone is replaced by a conglomerate in the upper part of the limestone of the Olenus Zone. At Karlevi and Eriksøre the Peltura Zone still has a thickness of $1,40 \mathrm{~m}$, whereas the Acerocare Zone is missing. At Borgholm the whole of the Upper Cambrian is concentrated in a conglomerate, $\mathbf{0 . 4 5} \mathrm{m}$ thick, which also includes components of earlier, broken-down deposits in the vicinity. At Djupvik the conglomerate contains some of the forms of the Peltura Zone together with Middle Cambrian fossils, which here too lie in secondary position. From this it can be seen that in Upper Cambrian times Öland lay very close to a coast which must have run obliquely across the present island and was pushed forward and back somewhat, and at any rate twice reached as far south as to Karlevi and Eriksøre, i. e. in the period with Eurycare and Leptoplastus and also in the period with Acerocare.

In G otland there are no Upper Cambrian sediments at all. As was the case in the latter part of Middle Cambrian times, this region lay above the surface of the sea.

In $\mathrm{N}$ ä $\mathrm{rke}$ the development of the Upper Cambrian is if anything an intermediate form between that in Scania and Bornholm on the one hand and Öland, Öster- and Västergötland on the other, as in the lower part, the zone with Agnostus pisiformis and the Olenus Zone there are continuous limestone beds corresponding to Stora Orstensbanken in Västergötland, but not so thick as, and less constant in their development, than the other two localities. At Latorp the limestone bed of the Agnostus pisiformis Zone lies directly over the Middle Cambrian Exporrecta Conglomerate. In several localities the limestone bed of the Olenus Zone is conglomeratic in its upper part, and the conglomerate contains Orusia lenticularis. We know the zone with Eurycare and Leptoplastus only from the easterly occurrences, it being missing to the west and north. The three lower sub-zones of the Peltura Zone occur everywhere, and their thickness is much greater than that of the underlying zones. They are different in development, too, for the shales completely dominates the limestone facies. The thickness increases in all zones from northwest to southeast. WESTERGARD thinks that the slight thickness of the lower zones may be the result of the sea floor in this period (up to and including the Eurycare Zone) being very close to the surface of the water, or sometimes above it (WESTERGARD 1922, 1940).

Judging from all the information it would seem that in the earlier part of Upper Cambrian times we have shallow water and neritic sediments, with the coast lying to the west or northwest. 
In Östergötland we know the Upper Cambrian only from a few well-scattered limestone quarries, from erratics and from borings. The thickness is very slight, $5 \mathrm{~m}$ to the east and $9 \mathrm{~m}$ to the west. At the bottom there is a limestone bed about $1 \mathrm{~m}$ thick, Stora Orstensbanken, which is conglomeratic in its upper part and comprises the three lower zones. The Eurycare Zone and the Peltura Zone are developed as alum shale with rows of stinkstone lenses sometimes completely grown together. The Acerocare Zone and the upper part of the Peltura Zone are missing. In the south quarry at Knivinge the Cambrian terminates upwards with a stinkstone bed that is partly conglomeratic. WESTERGARD interprets this as meaning that at the close of the Cambrian period Östergötland lay above the surface of the sea (Westergard 1928, 1940). The conglomerate in the St. Orstensbank also indicates that in the time between Olenus and Orusia relatively shallow-water sediments were laid down in Östergötland.

In Västergötland there is ample opportunity for studying the Upper Cambrian sediments, which are distributed over a large area. As a result we find that even if developments in the main are the same everywhere, there are several local phenomena.

Farthest west at Halle- and Hunneberg the Acerocare Zone and the two uppermost sub-zones of the Peltura Zone are missing. The remainder of the series consists of limestone beds separated by alum shale. The corresponding part of the Peltura Zone has a thickness of $2.5 \mathrm{~m}$. One particularly remarkable feature is that here the Eurycare Zone has a thickness of $0.5-0.8 \mathrm{~m}$ and that it lies in the upper part of a limestone bed which in its lower part includes Orusia lenticularis and is separated from the limestone bed of the Olenus Zone by a layer of alum shale $0.5-1.5 \mathrm{~m}$ thick. Thus here to the west we have only a lacuna, lying at the top of the series. It is not marked by any conglomerate, however, for the upper limestone bed at Nygard on the west side of Hunneberg is overlain directly by Dictyonema Shale and at the other localities by the Ceratopyge layers.

At Kinnekullen conditions are somewhat different. The Acerocare Zone is known as a continuous limestone bed which is overlain directly by the Ceratopyge deposits. The Peltura Zone consists of alum shale with numerous flat and sometimes very densely placed limestone lenses, or continuous limestone beds, especially in the upper part. The Eurycare Zone, the Orusia Zone and the Olenus Zone together form the so-called Stora Orstenbanken, a stinkstone bed $1-1.5 \mathrm{~m}$ thick, of which the upper part contains a conglomerate with a mixture of the faunas of the Eurycare Zone and the Orusia Zone, and occasionally elements of the faunas of both the lower part of the Peltura Zone and 
the Olenus Zone. WESTERgÅn reads this to mean that the entire region in the time prior to the development of the Stora Orstensbanken was subjected to level changes (possibly oscillatory) which lifted the sea floor up to just below the surface. Parts of the region seem to have been left quite dry at times.

In Billingen both the Acerocare Zone and the upper sub-zone of the Peltura Zone are missing, and the latter's upper part is sometimes conglomeratic. The only sections of the underlying parts are to be found in the northern tip. There, however, the zone with Eurycare and Leptoplastus is developed in the form of alum shale with thin stinkstone lenses and it has a thickness of $0.5 \mathrm{~m}$. The conglomerate in the Stora Orstensbanken comprises the Orusia Zone only.

In Falbygden the Acerocare Zone and the sub-zone with Parabolina longicornis are also missing. The upper part of the Peltura Zone is everywhere conglomeratic and bears traces of erosion. As far as can be seen from the literature (Westergård 1922, Thorslund 1937) there seem to be exceptions in some of the limestone quarries on the west side of Mösseberg and at the stone quarry southeast of Ålleberg, i. e. in the most southwesterly and westerly part of the whole region.

The development of the Eurycare Zone varies also from place to place. Farthest east, on the east side of Hvarvsberg, and farthest west on the west side of Mösseberg, its development is almost the same as on Kinnekulle, whereas on the northeast corner of Mösseberg, i. e. midway between the two former localities, together with the Orusia Zone it represents the main part of Stora Orstensbanken, while at the same time the Olenus Zone, in constrast to the other localities, is only thin here and at places is even missing.

In South Norway there are Upper Cambrian sediments at several places, both in the Oslo area proper and at Mjøsen (BRøgGer 1878, 1882, 1884, Holtedahl 1907, 1915, Strand 1929). It is difficult, however, on the basis of the literature to form any real idea of details of the development of the series. At most places developments seem to be similar to those in Scania and Bornholm, with alum shale facies as the predominant facies and the limestone more subordinate in the form of lenses. All zones seem to be represented, including the Acerocare Zone, which is to be found at any rate at Slemmestad.

The picture thus arrived at is very similar to that of conditions in the Middle Cambrian, figs 15-16. There is still a land region on the east, its coast stretching from the east side af Storsjön in Jämtland, through western Dalecarlia and then bending to the south. It is traceable north of Västergötland as well as north and west of Närke, and it also passed across the north of Öland almost in the direction of north 


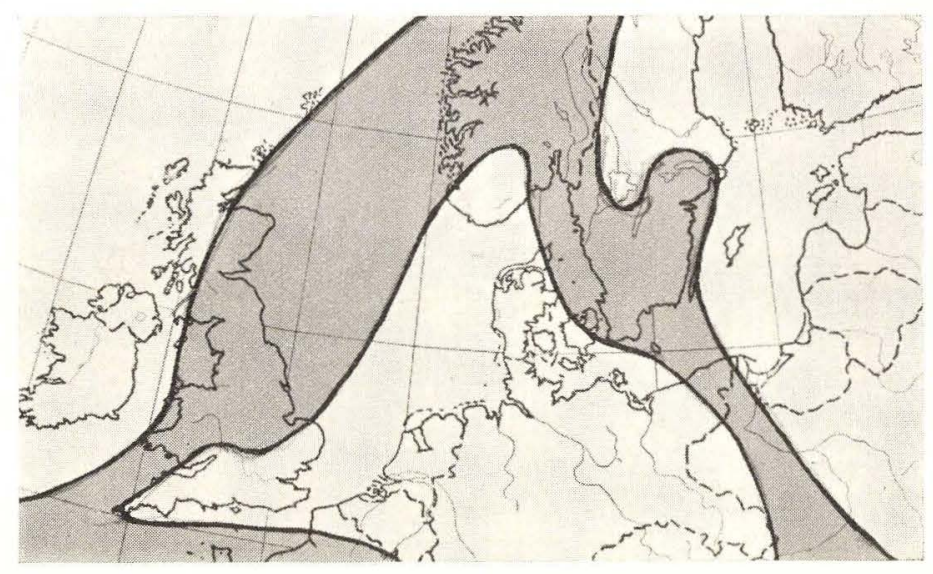

Fig. 15. Distribution of sea and land in the greater part of Upper Cambrian times.

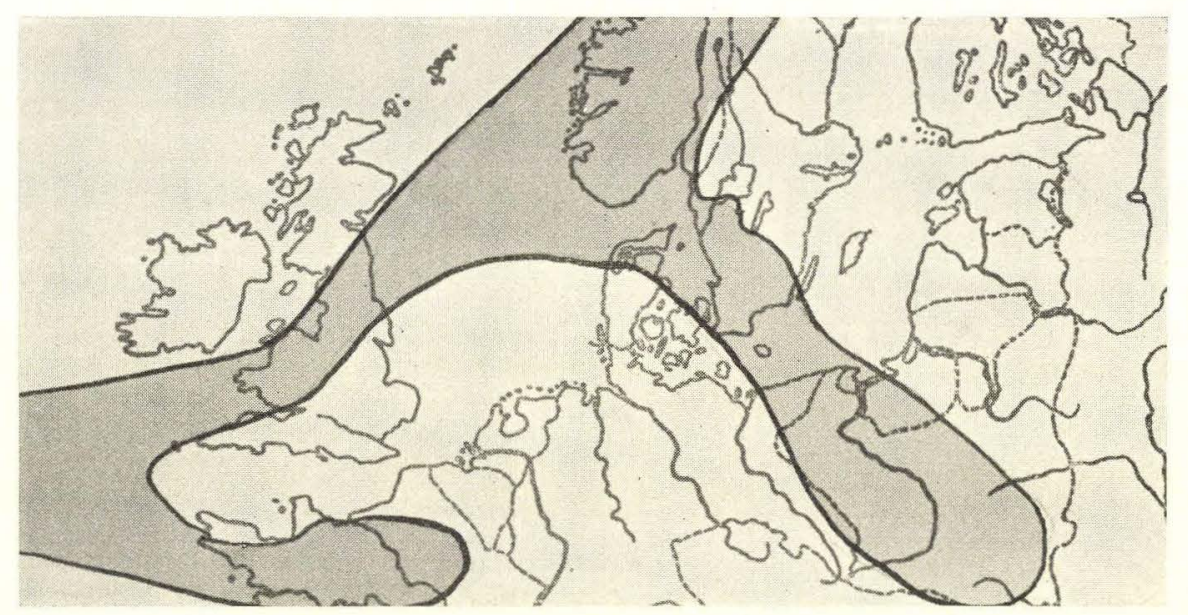

Fig. 16. Distribution of sea and land in the Acerocare period. 
to south. The development of the Upper Cambrian in Västergötland shows that the coast of this easterly land at times was farther away, at others nearer. It seems to have had its maximum expanse in the period with Orusia or Eurycare and at the close of the Cambrian period. The various local deviations within the different parts of Västergötland might perhaps be due to uplifts at the close of the period both eastwards and farthest west, whereas there was little uplift in the central parts (Kinnekulle and the northern point of Billingen), or at any rate occurred there only later, at the beginning of the Ordovician, when on the other hand the most westerly and southerly parts had again become submarine.

In order further to complete the picture of the palaeogeographic conditions in Upper Cambrian times it wills, as in the case of the Middle Cambrian, be advisable first to glance at the other European occurrences.

The British Is les. Here the Upper Cambrian consists of the so-called Lingula Flags, which are divided and parallelized with Scandinavia in the following manner:

Scandinavia.

British Isles.

Zone with Acerocare.

» $\gg$ Peltura and Sphaerophthalmus.

» " Eurycare and Leptoplastus. Dolgelly Beds.

» » Orusia lenticularis.

$»$ Olenus.

Ffestiniog Beds

(with Lingulella davisi).

» $\quad$ Agnostus pisiformis.

Maentwrog Beds.

From this division it will be seen that in the British Isles between the Olenus Zone and the Orusia Zone there is a section which in North Wales has a thickness of $610 \mathrm{~m}$ and which has no equivalent in Scandinavia, where on the contrary there are conglomerates and other signs of shallow-water sedimentation just at this place in the series. In South Wales Lingula Flags consist chiefly of shallow-water sediments (Pringle \& George 1937). The Midlands, on the other hand, have a fairly monotonous sedimentation with black shales deposited in deeper water (Соввоld 1927, Соввоld \& Pocock 1934, Groom 1902, Рососк \& Whitehead 1935). In North Wales conditions are rather different; at Harleck the Maentwrog and Ffestiniog Beds consist of sandstone and grits, and the black shales do not occur until we reach the Dolgelly Beds (Fearnsides 1905, Andrew 1910, Cox 1920, Nicholas 1915, 
Jones 1933). In Carnarvonshire, more to the north, the sediments become somewhat coarser the farther we go northeast (SMITH \& George 1935). Both in Carnarvonshire and on St. Tudval peninsula the upper part of the Cambrian was removed by erosion prior to the deposition of the Ordovician. Here we also find slight submarine volcanic activity, as at the boundary between Cambrian and Ordovician are the first forerunners of the Caledonian fold whereby northern Wales and Anglesey were raised up (SMITH \& GEORGE 1935).

In Central Europe it is in $\mathrm{N}$ or m a n d y that we first find deposits which - though with some uncertainty - can be placed to the Upper Cambrian. They are of coarse sandstone and arkoses and signify sediments in shallower water compared with the Middle Cambrian (Anthoine 1915, Bubnoff 1930).

In B elg i u m (the Brabant massif and Venn) Becker (1938) places the phyllites at Vielsam to the Upper Cambrian.

In G e r m a n y BuBnoff hesitatingly refers the pre-Devonian phyllites at Hunsrück and Taunus to the Cambrian, whereas on the east the Upper Cambrian is missing both in Frankenwald and in Silesia, and these regions as well as $\mathrm{B}$ o h e $\mathrm{m}$ i a lay above the surface of the sea. In Upper Cambrian times in Bohemia there was lively volcanic activity.

It is only when we get to the Lysa Gora area of Poland that we again encounter marine Upper Cambrian with a fauna having a number of forms in common with the Eurycare Zone and the Peltura Zone in Scandinavia. The rocks consist of shale and quartzite. Thus the total picture of the palaeogeography in Upper Cambrian times may be visualized almost as shown in fig. 15. The sea still has an arm running down the west side of the Russian shield, and the coast now lies considerably south of Bornholm. This description corresponds almost to the one given by BORN (1926). It differs from BECKER's (1938), who regards the south of England as an island. Naturally it is impossible to decide what is right here. These however are details about which nothing even approximately certain can be said. There is also the possibility that at certain periods Smaland lay as an island in the Upper Cambrian sea. 


\section{Chapter V. Tectonics.}

With regard to their sedimentation the above-described parts of the South-Scandinavian Cambro-Silurian regions may be divided into three areas:

1) The Mjøsen - Oslo - Scania area.

2) East and Middle Sweden (comprising Öland, Gotland, Öster- and Västergötland, and Närke); this also includes Estonia.

3) Bornholm.

1) The Oslo-M ø.sen-Scania a rea is characterized by a very monotonous series of sediments, mostly consisting of shale facies without intra-formational conglomerates or other indications of interruptions in the series. Limestone facies occur chiefly in the form of more or less sporadic calcareous lenses, and it is only in the zone with Paradoxides forchhammeri that we find a continuous limestone bed. In the region between Mjøsen and Oslo, especially in the lower part of the series, we find conglomerates lying at rather different levels as a consequence of the continued transgression here, a transgression which concluded with the uniting of the sea coming from the north with that coming from the south. The series here was deposited during a constant and smooth submergence, which proceeded relatively slowly but without a break, or possibly with only one interruption in the period with Paradoxides forchhammeri.

2) East and $\mathrm{Middle} \mathrm{S}$ weden forms a distinct contrast to the first area. Here there is a constant interchange of shale and limestone facies, so that sometimes the one, sometimes the other predominates, and we find continuous limestone beds at several levels. In association with them there are also conglomerates and lacunae in the series. The sediments were laid down in relatively shallower water nearer to the coast than those in the first area, and with repeated alternations between transgression and regression. 
3) B or nholm occupies what is almost an intermediate position between 1) and 2), as the series in the Middle Cambrian is of a character similar to that of area 2), whereas in the Upper Cambrian it is more of the character of area 1 ).

Tectonically the Mjøsen-Oslo-Scania area has almost the character of a geosyncline, one that has previously been studied by Troedsson (1923, 1931), but for a later point of time. Frebold has also examined this difference within the Scandinavian Cambro-Silurian regions more thoroughly (FrEBOLD 1928); he considers that the fossil concentrations he finds in the zone with Olenus, the zone with Orusia lenticularis and the zone with Peltura scarabaeoides indicate very shallow-water deposition and therefore are a sign of the termination of a sedimentation cycle, and consequently again a sign of an uplift, or at any rate a cessation of the Iransgression. For the Mjøsen-Oslo area, however, it is very difficult from the available literature to form any real idea of the course of sedimentation in the various horizons, and, as there are several possibilities for the interpretation of these fossil concentrations, as shown in Chapter III b, the correctness af FrEBOLD's conclusions on this point must be viewed at any rate with reserve. FrEBOLD also says that the zone with Paradoxides ölandicus is missing in Scania, and that in it there is a conglomerate at Mjøsen. This conglomerate, however, is no sign of an uplift, but lies in front of the northern sea which in this period is in a constant state of transgression. As regards Scania it is true that we have no fossils from this zone, but sedimentation still takes place. For example the fragment limestone at Andrarum is referred to the zone with Paradoxides ölandicus (MoвERG 1910), and there is no sign of a regression in this period here either. From all appearances there was, as already stated, a continuous submergence throughout the whole of the Middle and Upper Cambrian periods; on the other hand it must be admitted that as here we have on the whole deeper water and sediments less littoral in character, slight oscillations will be more difficult to observe in this region than in regions with more distinctly littoral sediments. The Andrarum Limestone alone might indicate a general decrease in the depth of water and therefore possibly an uplift in this area too.

The Middle and East Sweden area has more the character of a shelf region, with sediments deposited near the littoral zone. Among the occurrences in this area Estonia, Gotland and northern Öland form a separate group. During long periods of the Middle and Upper Cambrian time these areas lay above the sea and represent a collective region with a distinct tendency towards uplift in this time. The uplift was greatest and longest sustained towards the east, and it gradually spread 
westwards. In the southern part of Öland this uplift seems to have attained its maximum in the period with Paradoxides forchhammeri, whereafter it was succeeded by a very slow sinking. The alternations in the facies we encounter in South Öland are not necessarily due to direct epirogenetic movements; their cause may very well be that both sedimentation and sinking may have proceeded at rather different velocities, whereby now one, now the other of the two processes predominated.

Västergötland and western Närke form another sub-group within this area. Here we encounter signs of uplift in the zone with Paradoxides forchhammeri, the zone with Orusia lenticularis and with Eurycare, and at the close of the zone with Peltura and Sphaerophthalmus. As will appear from the description of the palaeogeographic development, however, there are several local differences within both these areas. In the zone with Paradoxides forchhammeri the uplift is most pronounced in eastern Västergötland (Kinnekulle and Billingen with the Exporrecta Conglomerate), whereas it is less so towards the west (Halleand Hunneberg). The uplift in the zones with Orusia and Eurycare is likewise most distinct on Kinnekulle and in Falbygden, but less so to the west at Hunneberg, and, remarkably enough, also less pronounced on the northern point of Billingen. The latter, however, may be due to local unevenness in the sea floor and consequent disturbances in the balance between accumulation and erosion. The uplift at the close of the Cambrian period is most pronounced farthest east (East Falbygden) but occurs somewhat later at Kinnekulle (with the beginning of the Ordovician), and still later to the west and south (Hunneberg and southwest Falbygden not until the close of the period with Dictyonema Shales).

Developments in Östergötland are very curious. Here there is no trace of any uplifting tendency in the zone with Paradoxides forchhammeri, but distinct traces in the other two zones already mentioned. Frebold (1928) regards Västergötland, Gotland, North Öland and Estonia as threshold regions with distinct movements as compared with the general epirogenetic movements in the total Fenno-Scandian shield; and as early as in 1916 HögBom, and later AskLund in 1923, voice the supposition that the movements along the faults which now limit several of the Middle Swedish Cambro-Silurian regions were already in process while the Cambro-Silurian was being deposited, and that the faults occurred at a still earlier juncture. Frebold holds that these threshold regions throughout the entire Cambro-Silurian display a constantly upward tendency in contrast to the Baltic shield as a whole, which in Palaeozoic times passed through a development with repeated 
uplifts and sinkings. As Frebold also points out, however, the uplift tendency in the zone with Paradoxides forchhammeri, in the zone with Orusia and in the upper part of the zone with Peltura was so general that the movements, at any rate those in Middle and Upper Cambrian times, must be regarded as synchronous throughout the entire area, (it should be recalled, however, that FrEBOLD's investigations extend throughout the whole of the Cambro-Silurian) wherefore it is probable that in Cambrian times it was one tectonic whole.

3) In Bornholm conditions are quite different. Here we have a continuous tendency towards uplift in the entire period from the time with Holmia kjerulfi up to the time with Ctenocephalus exsulans, both inclusive, whereafter there was a slight submergence, one that ceased in the time with Paradoxides davidis and that with Par. forchhammeri, whereafter, as in Scania, it was replaced by another submergence which lasted throughout the remainder of the Cambrian and some way into the Ordovicium. A cessation of this submergence period can only be imagined in the time with Olenus and in that with Orusia lenticularis. Thus in the Upper Cambrian period Bornholm passed through a development very similar to that of the geosynclinal Oslo-Scania area, whereas in Middle Cambrian times, and for that matter also in Lower Cambrian times, the development was distinctly shelf-like in character. But now there is the additional fact that this shelf is separated from the Middle and East Swedish shelf by the Scania geosynclinal region, so that from the time with Holmia kjerulfi it was not part of the Fennoscandian-Baltic shield but of the so-called Pompeckjschwelle. Regarding the latter's direction and limits, however, there is some uncertainty. BORN considers it in Cambrian times to be the so-called Jutlandic island, which ran northwest-southeast up through Denmark and North Germany, and Becker inclines to the same view (BorN 1926, BEcker 1938). On the other hand BubNoff considers that the threshold between the Baltic-Scandinavian sea and the North German-Bohemian sea in Cambrian times ran more in the direction of east-west (BuBNofF $1930)$.

Thus in Middle and Upper Cambrian times it is possible to distinguish between three tectonic units:

1) The border of the Fennoscandian-Baltic shield. Middle Sweden, Öland, Gotland and Estonia.

2) Mjøsen - Oslo - Scania's geosynclinal area.

3) The northeast border of the Pompeckjschwelle (Bornholm).

To all appearances these three units are independent in their movements, but it should be borne in mind that vertical movements with small amplitudes are more difficult to demonstrate in the central parts 
of the geosynclinal region itself than in its marginal regions, and the almost universal distribution of the Andrarum Limestone would seem to suggest that at any rate in the period with Paradoxides forchhammeri there was a collective cessation of the submergence everywhere in the Scandinavian-Baltic region.

The total picture of the tectonic developments in Northern Europe in Cambrian times is thus that a geosynclinal region is gradually developed along the west border of the Fennoscandian-Russian shield, from Poland across Scania and the Oslo area to Mjøsen, where it encounters the true Caledonian geosyncline which forms the mountain range region, and from there runs southwest down across the British Isles. Middle Sweden and Balticum form the shelf region of the Fennoscandian shield with on the whole shallow-water sediments. West of the Oslo-Scanian geosyncline lies an area of resistance, comprising the east part of the North Sea and western Denmark. This position is held not only throughout the whole of the Cambrian but at any rate through most of the Ordovician as well; an examination of the latter period, however, is beyond the scope of the present work. 


\section{Literature.}

D. G. U. = Danmarks Geol. Undersøgelse, København.

D. G.F. = Medd. fra Dansk Geol. Forening, København.

S.G.U. = Sveriges Geol. Undersökning, Stockholm.

G.F.F. = Geol. Föreningens Förhandlinger, Stockholm.

N. G. U. = Norges Geol. Undersøkelse, Oslo.

N. G. T. $=$ Norsk Geol. Tidsskrift, Oslo.

Andersson, I. G.: Notes on the occurrence of the Paradoxides ölandicus Zone in Nerike. Bull. Geol. Inst. Univ. Upsala I. 1893.

-. Über kambrische und silurische phosphoritische Gesteine aus Schweden. Ibid. IV. 1895.

- Om Fosforitbildning och fosforitförande Sediment. G. F. F. 19. 1897.

Andree, K.: Über Vorkommen und Herkunft des Schwerspates am heutigen Meeresboden. Centrbl. f. Min, etc. Stuttgart. 1918.

- Geologie des Meeresboden II. Berlin. 1920.

Andrew, A. R.: The Geology of the Dolgelly Gold-belt. Merionethshire. Geol. Mag. London. 1910.

Androussow, N.: La Mer noire. Guide des Excursions du VII Congres intern. geol. Nr. 29. St. Petersburg. 1897.

Anthonne, R.: Contribution a l'Etude du Bassin silurique de Mortan (Basse Nordmandi). Ann. soc. geol. Belg. 41. Liège. 1915.

Apstein, C.: Bodenuntersuchungen in Ost- und Nordsee. Sitzber. Ges. naturf. Freunde. Berlin. 1917.

Archanguelsky, A. D.: On the Black Sea sediments and their importance for the study of the sedimentary rocks. Bull. soc. d. naturalistes de Mouscou. Sect. geol. n. s. t. 35. 1927.

Asklund, B.: Bruchspaltenbildungen in südostlicher östergötland. G.F.F. 45. 1923.

- Fennoskandias ålder, kontinentrörelser och relief; in Ramsay: Geologiens Grunder. II. Tredje Upplagan. Stockholm. 1931.

- och Thorslund, P.: Fjällkedjerandens bergbygnad i norra Jämtland och Angermanland. S. G. U. Ser. C. Nr. 382. 1934.

Bavendam, W.: Die farblosen und roten Schwefelbakterien des Süss- und Salzwasser. Pflanzenforschung. herausg. v. R. Kolkwitz. 2. Jena. 1924.

- Die mikrobiologische Kalkfällung in der tropische See. Arch. für Mikrobiologie. 3. Stuttgart. 1932.

Becker, H.: Mittel- und Westeuropa in Regionalgeol. d. Erde, herausg. v. Andree, Brouwer u. Bucher. Leipzig. 1938. 
Berz, K.: Über die Natur und Bildungsweise der marinen Eisensilikate. Forsch. Geol. u. Paläont., herausg. bei Soergel. II. Berlin. 1926.

Behrend, F. u. Berg, G.: Chemische Geologie. Stuttgart. 1927.

BцACK, M.: The precipitation of calcium carbonate on the Great Bahama Bank. Geol. Mag. 70. London. 1933.

- Algal Sediments on Andros Island, Bahamas. Phil. transact. royal. soc. London. Ser. B. vol. 222. 1933.

Born, A.: Das Kambrium; in Salomon: Grundzüge d. Geologie II. Stuttgart. 1926.

Bruce, J. R.: Physical factors on the sandy beach. Journ. mar. biol. Ass. N. S. 15. Plymouth. 1928.

Brøgger, W. C.: Paradoxidesskiferne ved Krekling. Nyt Magasin f. Naturv. 24. Oslo. 1878.

- Die Siluretagen 2. u. 3. in Kristianiageb. Universitetsprogram. Kristiania (Oslo). 1882.

- Spaltenverwerfungen in d. Gegend Langesund-Skien. Nyt Mag. f. Naturv. 28. Oslo. 1884.

von Bubnoff, S.: Geologie v. Europa. I. Berlin. 1926.

- Geologie v. Europa. II. Berlin. 1930.

BøgGiLD, O. B.: Meeresgrundproben d. Sibogaekspedition. Leyden. 1916.

Callisen, K.: Tenformede Tungspatkrystaller i Alunskiferen. D. G.F. 4. 1914.

Chouff, G.: Note preliminaire sur les niveau paläontologique des couches de Jince du cambrien moyenne sur le Vystrhov pres Jince. Vestnik stániho geol. Ustavo Ceskoslovenské Repl. II. Praha. 1926.

Clarke, F. W.: The data of geochemistry. U. S. geol. surv. Bull. 770. Washington. 1924.

Classen, T.: Periodisches Fischsterben in Walvis Bay South Vest Afrika. Paläobiologica III. Wien. 1930.

Coввоld, E. S.: Trilobites from the Paradoxides beds of Comley. Quart. journ. geol. soc. 67. 1911.

- The Trilobite Fauna of the Comley Breccia Bed. Quart. journ. geol. soc. 69. 1913.

- The Cambrian horizons of Comley. Quart. journ. geol. soc. 76. 1920.

- The stratigraphy and geol. structure of the Cambrian area of Comley. Shropshire. Quart. journ. geol. soc. 83. London. 1927.

- Additional fossils from the Cambrian rocks of Comley. Ibid. 87. 1931.

- and Рососк, R. W.: The Cambrian area of Rushton, Shropshire. Phil. trans. royal. soc. London. ser. B. vol. 223. 1934.

Correns, C. W.: Der Odershäuser Kalk im oberen Mitteldevon. Neues Jahrb. f. Min. etc. B. B. 49. Stuttgart. 1923.

Cox, A. H.: The geology of the district between Abereiddy and Abercastle, Pembrokeshire. Quart. journ. geol. soc. 71. London. 1915.

- and Weels, A. K.: The lower palaeozoic rocks of the Arthoy-Dolgelly district. Merionetshire. Ibid. 76. 1920.

DALY, R. A.: The limeless ocean of Precambrian time. Amer. Journ. of science. 173. New Haven. 1907.

- Some chemical conditions in the Pre-Cambrian Ocean. Compt. Rend. Congr, geol. intern. Stockholm. 1910.

- Geology of the North American Cordillera at the Forty-ninth Parallel. II. Mem. 38. geol. surv. og Canada. Ottawa. 1912. 
Deecre, W.: Die phosphoritführenden Schichten Bornholms. Mitt. d. naturv. Ver. Neuvorpommern u. Rügen. 29. Greifswald. 1897.

Doss, B.: Ref. af Silberberg, Weinberg, Wassiljeff, Jegunoff og Siderenkos works about the russian Limans. Neues Jahrb. f. Min. etc. Stuttgart. 1900 I. 1901 II.

- Melnikowit, ein neues Eisenbisulphid und seine Bedeutung für die Genesis d. Kieslagerstätten. Zeitschr. f. prakt. Geol. 20. Berlin. 1912.

Drew, G. H.: On the precipitation of calcium carbonate in the sea by marine bacteria. Papers from the Tortugas Lab. 1914.

Fearnsides, W.: On the geology of Arenig Fauna and of Moel Llyfnant. Merionethshire. Quart. journ. geol. soc. 61. London. 1905.

- Geology of North Wales. Proc. geol. assoc. London. jubel vol. 1910.

Forchнammer, G.: Danmarks geognostiske Forhold. Indbydelsesskrift til Reformationsfesten 14. November 1835. København.

- Geognostiche Studien am Meeresufer. Neues Jahrb. f. Min. etc. Stuttgart. 1841.

FREBold, H.: Über züklische Meeressedimentation. Leipzig. 1925.

- Die paleogeographische Analyse der epirogenen Bewegungen und ihre Bedeutung für die Stratigraphie. Geol. Arch. Berlin. 1927.

- Deutung und erdgeschichtlicher Wert der Fossilkoncentration im Paläozoikum des Baltikums. Zeitschr. f. Geschiebef. 4. Berlin. 1928.

- Zentren epirogener Hebung als Schwellengebiete in das paläozoischen Meeren des baltischen Schildes und seiner randlichen Teile. Neues. Jahrb. f. Min. etc. B. B. 59. B. Stuttgart. 1928.

Goebel, A.: Die heilsame Meeresschlam an den Küsten der Insel Øsel. Arch. f. die Naturkunde Liv-, Ehst- und Kurland. I. Dorpat. 1857.

Gripenberg, S.: A study of the sediments of the North Baltic and adjoining seas. Fennia 60. Helsingfors. 1934.

Groom, T.: The sequence of the Cambrian and associated beds of Malvern hills. Quart. journ. geol. soc. 58. London. 1902.

Grönwall, K. A.: Studier öfver Skandinaviens Paradoxideslag. G. F. F. 24. 1902.

- Bornholms Paradoxideslag og deres Fauna. D. G. U. II. R. Nr. 13. 1902.

Gürich, G.: Mimaster hexagonalis, ein neuer Krustaca aus dem Budenbacher Dachschiefer. Pal. Zeitschr. 13. Berlin. 1931.

HadDing, A.: The pre-quarternary sedimentary rocks of Sweden. I. II. Lunds Univ. Årskrift. N. F. Avd. 2. Bd. 23. 1927.

- The pre-quarternary sedimentary rocks of Sweden. III. Ibid. 25. 1929.

- - IV. Ibid. 28. 1932.

— - V. Ibid. 29. 1933.

Hagmeier, A.: Die Bodenfauna d. Ostsee im April 1929. Ber. deutch. wiss. Comm. z. Meeresforschung. N. F. 5. Berlin. 1930.

Hansen, KaJ: Den kambriske Sandsten paa Hunneberg i Västergötland. D.G.F. 8. 1933.

— Die Gesteine des Unterkambriums auf Bornholm. D. G. U. II. R. 62. 1936.

- Om Glauconitens Sedimentering med særlig Henblik paa Kornstørrelsen. D. G. F. 9. 1937 a.

- Sammenlignende Studier over Kambriet i Skåne og paa Bornholm. D. G. F. 9. 1937 b.

- Strukturen i nogle bornholmske Kalksten. D. G. F. 9. 1938. 
Harder, E. C.: Iron-depositing bacteria and their geological relations. U. S. geol. surv. Prof. paper 113. Washington. 1919.

Неснт, F.: Der chemische Einfluss organischer Zerzetzungsstoffe auf das Benthos. Senckenbergiana. 14. Frankfurt a. M. 1932.

- Der Verbleib der organischen Substans d. Tiere bei meerische Einbettung. Ibid. 15. 1933.

Hedström, H.: Till frågan om fosforitlagrens uppträdande och förekomst i de geologiska formationerna. G. F. F. 18, 1896.

- och Wiman, C.: Beskrifning till Berggrundskarta. S. G. U. Ser. A 1 a. Blad 5. 1906. (öland).

- Remarks on some fossils from the diamond boring at the Visby cement factory. S. G. U. Ser, C. 314. 1923.

Häntzschel, W.: Die Schichtungsformen rezenten Flachmeer-Ablagerungen. Senckenbergiana. 18. Frankfurt a. M. 1936.

Holm, G. och Munthe, H.: Kinnekulle, dess geologi och den tekniska användningen af dess bergarter. S. G. U. Ser. C. 172. 1901.

Holst, N. O.: Beskrifning till Kartbladet Simrishamn. S. G. U. Ser. Aa. 109. 1892.

Holtedahl, O.: Alunskiferfeltet ved Øjeren. N. G. U. Nr. 45. 1907.

- Hennungbygdens Alunskiferfelt. N. G. T. 2. 1911.

- Iagttagelser over Fjeldbygningen omkring Randsfjordens Nordende. N. G. U. 75. 1915.

- Om Fordelingen af Hav og Land i det nordatlantisk-arktiske Omraade i Jordens Oldtid. Naturen 1919. Bergen.

— \& Shetelig, J.: Kartbladet Gran. N. G. U. 97. 1923.

- Forsforsyreindholdet i den kambrosiluriske Lagrække ved Oslo. Statens Raastofkomites Publikationer 26. Oslo. 1927.

- The geology of parts of southern Norway. Proc. geol. assoc. London. 1934.

- \& Bailey, E. B.: Nordwestern Europe Caledonides. In Regional-Geologie d. Erde, herausg. v. Andree m. fl. Leipzig. 1938.

Нӧявом, А. G.: Zur Mechanik d. Spaltenverwerfungen. Bull. geol. Inst. d. Univ. Upsala 13. 1916.

IlLing, V. C.: The paradoxides fauna of a part of the Stockinford Shales. Quart. journ. geol. soc. 71. London. 1915.

Jegunow, J.: Schwefeleisen und Eisenhydrat in den Böden der Limane und des Schwarzen Meere. Ann. geol. et min. d. l. Russie 2. St. Petersburg. 1897.

Jessen, W.: Über rezente und fossile Organismenpflaster. Pal. Zeitschr. 14. Berlin. 1932 a.

- Die postdiluviale Entwicklung Amrums und seine subfossilen und rezenten Muschelfplaster. Inagural Diss. Halle. 1932 b.

Johnson, D. W.: Shore processes and shoreline development, London. 1919.

Johnston, J. and Williamson, E. D.: The role of inorganic agencies in the deposition of calcium carbonate. Journ. of Geol. 24. Chicago. 1916.

Johnstrup, F.: Abriss d. Geologie von Bornholm. Führer d. Eksk. Deut. Geol. Ges. Berlin. 1891.

Jones, E. J.: Examination of nodular stones obtained by trawling off Colombo. Records of the geol. surv. of India. 21. Calcutta. 1883.

Jones, B.: The geology of the Fairnboune Llyngwill district, Merionethshire. Quart. journ. geol. soc. 89. London. 1933.

Kaiser, E.: Das Fischsterben in der Wallfischbucht. Palæobiologica. 1930. 
Karsin, F.: Les roches du Dinantien de Belgique. Comtes rendu. Congr. geol. intern. XIII. Liège. 1926.

Kellerman, K. F. and Sмith, N. R.: Bacterial precipitation of calcium carbonate. Journ. of Washington Acad. of Science. 4. 1914.

Kettner, R.: La geologique du cambrien de Skryje et Tyrevice, et de terrain envirronants. Sbornik, Státniko geol. Ustavo. Ceskoslovenské Rep. 3. Praha. 1923.

Linnarsson, G.: öfversigt af Nerikes öfvergångsbildningar. S. G. U. Ser. C. 21. 1875.

- De undre Paradoxideslag vid Andrarum. S. G. U. Ser. C. 54. 1882 a.

- \& Tullberg, S. A.: Beskrifning til Kartbladet Vreta Kloster. S. G. U. Ser. Aa. Nr. 83, 1882 b.

LübErs, K.: Die Entstehung der Gezeitenschichtung auf dem Watten im Jadebusen. Senckenbergiana. 12. Frankfurt a. M. 1930.

Magnusson, N. H., Muntme, H., Rosen, S.: Beskrivning till Kartbladet Mjölby. S. G. U. Ser. Aa. Nr. 150. 1922.

Marr, I. E.: The Stockdale shales of the Lake District. Quart. journ. geol. soc. 81 . London. 1925 .

Mc. Clendon, J. F.: On changes in the sea and their relations to organisms. Papers from the department of marine biology of the Carnegie Inst. of Washington. vol. XI. 1917.

Moberg, I. C.: Geol. Guide to Andrarum. Guide to Congres geol. intern. Stockholm. 1910.

- Historical-stratigraphical review of the Silurian of Sweden. S. G. U. Ser. C. 229.1911.

Munthe, H.: Beskrifning til Karibladet Kalmar. S. G. U. Ser. Ac. 6. 1902.

- Beskrifning til Kartbladet Falköping. S. G. U. Ser. Aa. 120. 1906 a.

- Beskrifning til Kartbladet Tidaholm. S. G. U. Ser. Aa. 125. 1906 b.

Murray and Irvine: On the coral reefs and other earbonate of lime formations in modern seas. Proc, roy. soc. Edinburg 17. 1891.

Murray, J.: On the deposits of the Black Sea. The Scot. Geograph. Mag. 16. Edinburg. 1900.

Nadson, G.: Beitrag zur Kenntnis der bacteriogenen Kalkablagerungen. Arch. f. Hydrobiologi 2.19 . Stuttgart. 1928.

Nathorst, A. G.: Om de kambrisk siluriska lagren vid Kiviks Esperød i Skåne. G. F. F. 3. 1877.

Nigholas, C.: The geology of the St. Tudwall peninsula. (Carnarvonshire). Quart. journ. geol. soc. 71. London. 1915.

Phillipi, E.: Über Dolomitbildung und chemische Abscheidung von Kalk in heutigen Meere. Neues Jahrb. f. Min. etc. Festband. Stuttgart. 1907.

PIA, J.: Einige allgemeine an die Algen des Paläozoikums anknüpfende Fragen. Pal. Zeitschr. 13. Berlin. 1931.

- Die rezenten Kalksteine. Tschermak min. u. petrogr. Mitt. Ergänzungsband. Wien. 1933.

PiCARD, E.: Das Algonkium von Rotstein bei Lichtenwerda im Vergleich mit demjenigen im Saekatal bei Prag, und über Kambrium bei Dobrilugh. Zeitschr. deut. geol. Ges. Monatsber. Berlin. 1928.

Pocock, R. and Whitehead, F. H.: The Welsh Borderland. Brit. reg. Geol. London. 1935.

Pompecks, J. F.: Die Fauna des Kambriums von Tyrovice und Skryje. Jahrb. geol. Reichsanst. Wien 45. 1895.

- Das Meer des Kupferschiefers. Branca Festskrift. Berlin. 1914. 
Poulsen, Chr.: Om Dictyograptusskiferen paa Bornholm. D. G. U. IV. R. Bd. 1. Nr. 16. 1922.

- Bornholms Olenuslag og deres Fauna. D. G. U. II. R. 40. 1923.

- Nogle hidtil ukendte Fossiler fra Bornholms Exsulanskalk. D. G. F. Bd. 10. Hefte 2. 1942.

Pratje, O.: Die Sedimente des Kurischen Haffes. Forschr. d. geol. u. Palæont. Berlin. 1931.

Pringle, J. and George, T. N.: South Wales. Brit. reg. geol. London. 1937.

Richardson, W. A.: The relative age of concretions. Geol. Mag. London. 1921.

Richter, R.: Tierwelt und Umwelt im Hunsrückschiefer. Senckenbergiana 13. Frankfurt a. M. 1931.

Schmidt, H.: Die bionomische Einteilung der fossilen Meeresböden. Fortschr. Geol. u. Pal., herausgeb. v. Soergel. Berlin. 1935.

Schneiderhörn, H.: Chalkographische Untersuchungen der Mansfelder Kupferschiefers. Neues Jahrb. f. Min. etc. B. B. 47. Stuttgart. 1923.

Schuchert, C. \& Dunbar, C. O.: A textbook of geology II. New York, 1933.

- - Stratigraphy of Western Newfoundland. Geol. soc. Amer. Mem. 1. New York. 1934.

Schucht, F.: Das Wasser und seine Sedimente im Flutgebiet der Elbe. Jahrb. preus. geol. Landesanst. 25. Berlin. 1904.

Schwarzbach, M.: Zur Stratigraphie des Kambrium in der Oberlausitz. Centrbl. f. Min. etc. Stuttgart. 1932. B.

Smetana: Sur les Paradoxides les plus ancien du Cambrien de Skryje et Tyrevice. Sbornik Státniho geol. Ustavo Ceskoslovenské Repl. I. Praha. $1919-20$.

Smith, B. and George, T. N.: North Wales. Brit. reg. geol. London. 1935.

Stille, H.: Grundfragen des vergleichende Tektonik. Berlin. 1924.

Sтrøм, K. M.: Land-Locked Waters. Skrift. udg. av Det Norske VidenskapsAkademi i Oslo. Mat.-nat. Klasse. 1936.

Strand, T.: The Cambrian beds of the Mjøsen district. N. G. T. 10. 1929.

Thonsen, P.: Vor Hjemstavn. Aakirkeby. 1931.

Thorslund, P.: Notes on the lower Ordovicium of Falbygden. Bull. geol. Inst. Univ. Upsala 27. 1937.

— \& Westergånd, A.: Deep boring through the Cambro-Silurian at File Haidar, Gotland. S. G. U. Ser. C. 415. 1938.

Trask, P. D.: Relation of salinity to the calcium carbonate content of marine sediments. U. S. geol. surv. Prof. papers. 186. Washington. 1937.

Trener, G.: Die Barytvorkommen von Alte Calirio. Jahrb. geol. Reichsanst. Wien 58. 1908.

Troedsson, G.: Grunddragen av skandinavisk-baltiska områdets paleogeo grafi i kambrosilurisk tid. Förh. ved det 17. skand. Naturforskermötet. Göteborg. 1923.

- De paleozoiska Bildningar i Ramsay: Geol. Grunder II. Tredie Upplagen. Stockholm. 1931.

Tullberg, S. A.: Agnostusarterne i de cambriske Aflagringarne vid Andrarum. S. G. U. Ser. C. 42.1880.

- Beskrivning til Kartbladet Øvedkloster. S. G. U. Ser. Aa. 86. 1882.

Twenhofel, W. H.: Black shales in making. Amer. journ. of science. New Haven. 1913.

- Treatise on Sedimentation. Baltimore. 1926. 
Ulrich, E. O.: Revision of the paleozoic system. Bull. geol. soc. Amer. 22. New York. 1911.

Walcott, C.: Precambrian algoncian algal flora. Smithsonian miscel. coll. Washington 64. 1914.

- Evidence of primitive life. Smiths. Inst. Ann. rep. Washington. 1916.

- Middle Cambrian algae. Smithson. miscell. coll. 67. Washington. 1919.

Wallerius, J. D.: Konglomerat inom kambriska Sandstenen i Djupadal, Västergötland. G. F. F. 50. 1928.

— Från Västergötlands Mellankambrium. G. F. F. 52. 1930.

Walther, J.: Die gesteinsbildende Kalkalgen des Golfes v. Neapel und die Entstehung structurloser Kalk. Zeitschr. deut. geol. Ges. Berlin. 1885.

- Einleitung in der Geologie. Jena. 1894.

Wasmund, E.: Biocoenose und Thanatocoenose. Arch. f. Hydrobilogie. 17. Stuttgart. 1926.

Vaughan, T. W.: Chemical and organic deposits of the sea. Bull. geol. soc. Amer. 28. New York. 1917.

Weigelt, J.: Angewandte Geologie und Paläontologie der Flachseegesteine und das Erzlager von Salzgitter. Fortschr. Geol. u. Pal. herausg. v. Soergel. Berlin. 1923.

- Die Bedeutung der natürliche Aufbereitung für die Geschiebeforschung. Zeitschr. f. Geschiebefor. 3. Berlin. 1927.

Westergård, A. H.: Sveriges Olenidskifer. S. G. U. Ser. Ca. 18. 1922.

— Om Östergötlands Kambrium. G. F. F. 50. 1928 a.

— \& Munthe, H.: Beskrivning til Kartbladet Skövde. S. G. U. Ser. Aa. 121. Andra Uppl. $1928 \mathrm{~b}$.

- A deep boring through middle and lower Cambrian strata of Borgholm, isle of Øland. S. G. U. Ser. C. 355. 1929.

- Om lagerserien i de nyfundna områdene med kambro ordovicisk berggrund i Slätbacken i östergötland och Erken i Uppland. G. F. F. 52. 1930.

- m. fl. Beskrivning til Kartbladet Lugnås. S. G. U. Ser. Aa. 172. 1931.

- Paradoxides ölandicus beds of öland. S. G. U. Ser. C. 394. 1936.

- Nya Diupborningar genom äldsta Ordovicium och Kambrian i östergötland och Närke. S. G. U. Ser. C. 437. 1940.

- Stratigraphic results of the boring through the Alum Shales of Scania made in 1941-1942. Lunds geol. Fältklub 1892-1942. Lund. 1942.

VogT, T.: Forholdet mellem Sparagmitsystemet og det marine Underkambrium ved Mjøsen. N. G. T. 7. 1924.

Wolansky, D.: Untersuchungen über die Sedimentationsverhältnisse der Schwarzen Meeres. (Ref.) Geol. Rundsch. 24. Leipzig. 1933.

WurM, A.: Über ein Vorkommen von Mittelkambrium im bayrischen Frankenwald bei Wildenstein. Neues Jahrb. f. Min. etc. B. B. 52. B. Stuttgart. 1925.

- Über eine neue mittelkambrische Fauna aus dem bayrische Frankenwald und ihre Bedeutung für die Stratigraphie des älteres Paläozoikums. Ibid. B. B. 59. B. 1928.

ØрIк, A.: Brachiopoda pretremata der estländischen ordovisischen Kukruse Stufe. Publ. geol. Inst. Tartu. 20. 1930.

Ørsted, H. C. og Esmarck, L.: Beretning om en Undersøgelse over Bornholms Mineralrige. København 1819. 
Fig. 1. Exsulans Limestone, Øleaa, Loc. 1. In the ground-mass of fine calcareous mud lie:

a. Quartz grains from the Rispebjerg Sandstone.

b. Numerous irregular (grey in the picture) lumps of glauconite, occasionally with clear calcite crystals along the margin.

c. Elongate fragments of trilobite shells. Slide 653. Magn. $18 \times .1$ nicol.

Fig. 2. Pale grey, finely crystalline Exsulans Limestone. Øleaa, Loc. 4, with small areas of coarser crystals forming a crystal mosaic.

Slide 714. Magn. $70 \times .1$ nicol.

Fig. 3. Limesand limestone from the Davidis Zone in Øleaa, Loc. 5. It consists of more or less rolled calcite grains with black, bushy figures.

Slide 665. Magn. $10 \times .1$ nicol. 


\section{Plate I.}
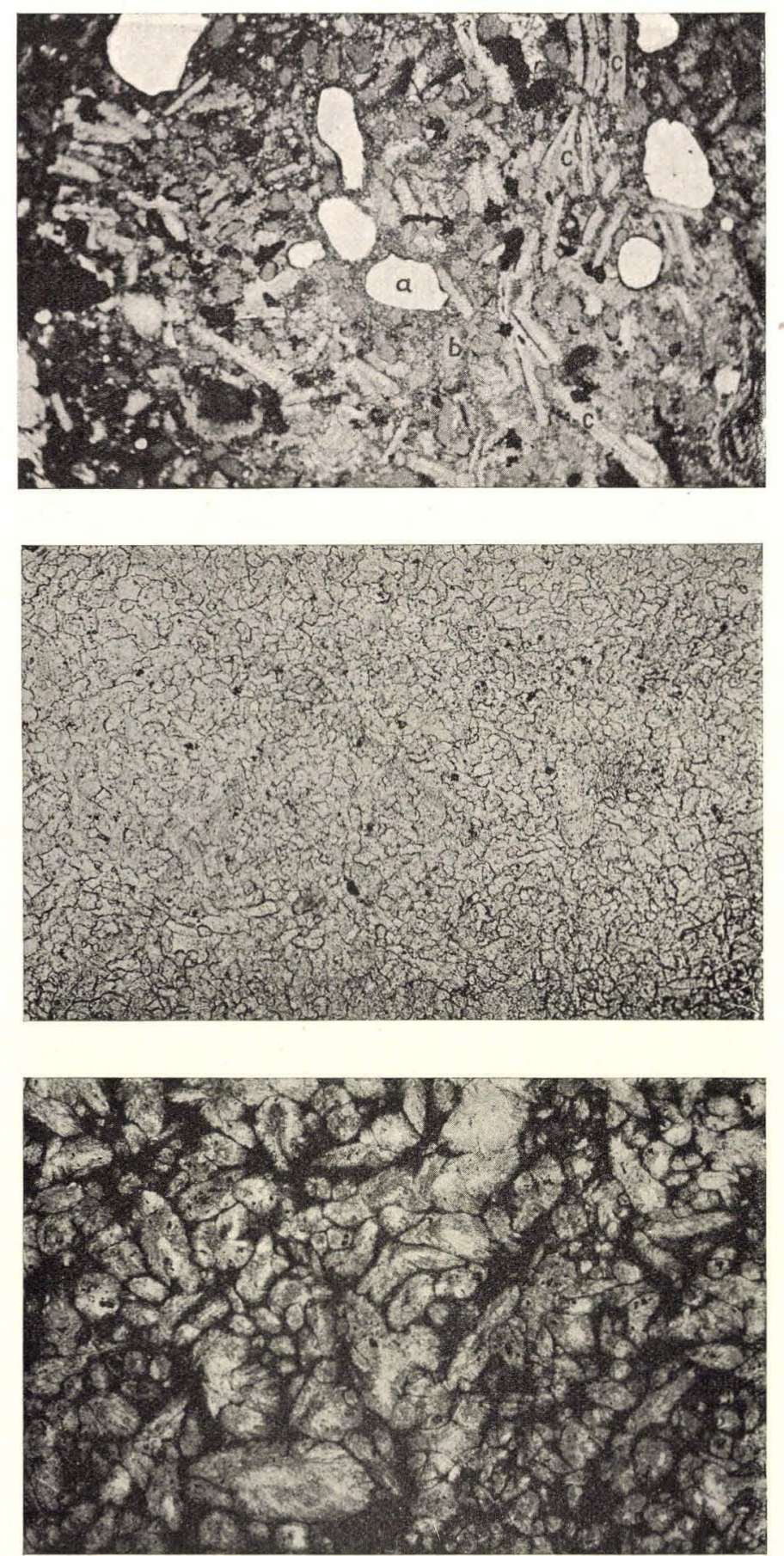
Fig. 1. The phosphorite horizon of the Davidis Zone. Øleaa, Loc. 5. The lightcoloured areas consist of fine, recrystallized calcareous mud with shell fragments and rolled quartz grains. The black areas are the phosphorite nodules.

Slide 667. Magn. $10 \times .1$ nicol.

Fig. 2. Same rock as Fig. 1. It shows Brachiopod shells full of small quartz grains.

Slide 668. Magn. $15 \times$. Nicols + .

Fig. 3. Phosphorite from the Davidis Zone at Læsaa, Loc. II. The white areas consist of clear calcite. The grey areas are brown to look at and are isotropic; presumably they consist of phosphorite. The black areas also contain large quantities of organic mud.

Slide 697. Magn. $35 \times .1$ nicol. 


\section{Plate II.}
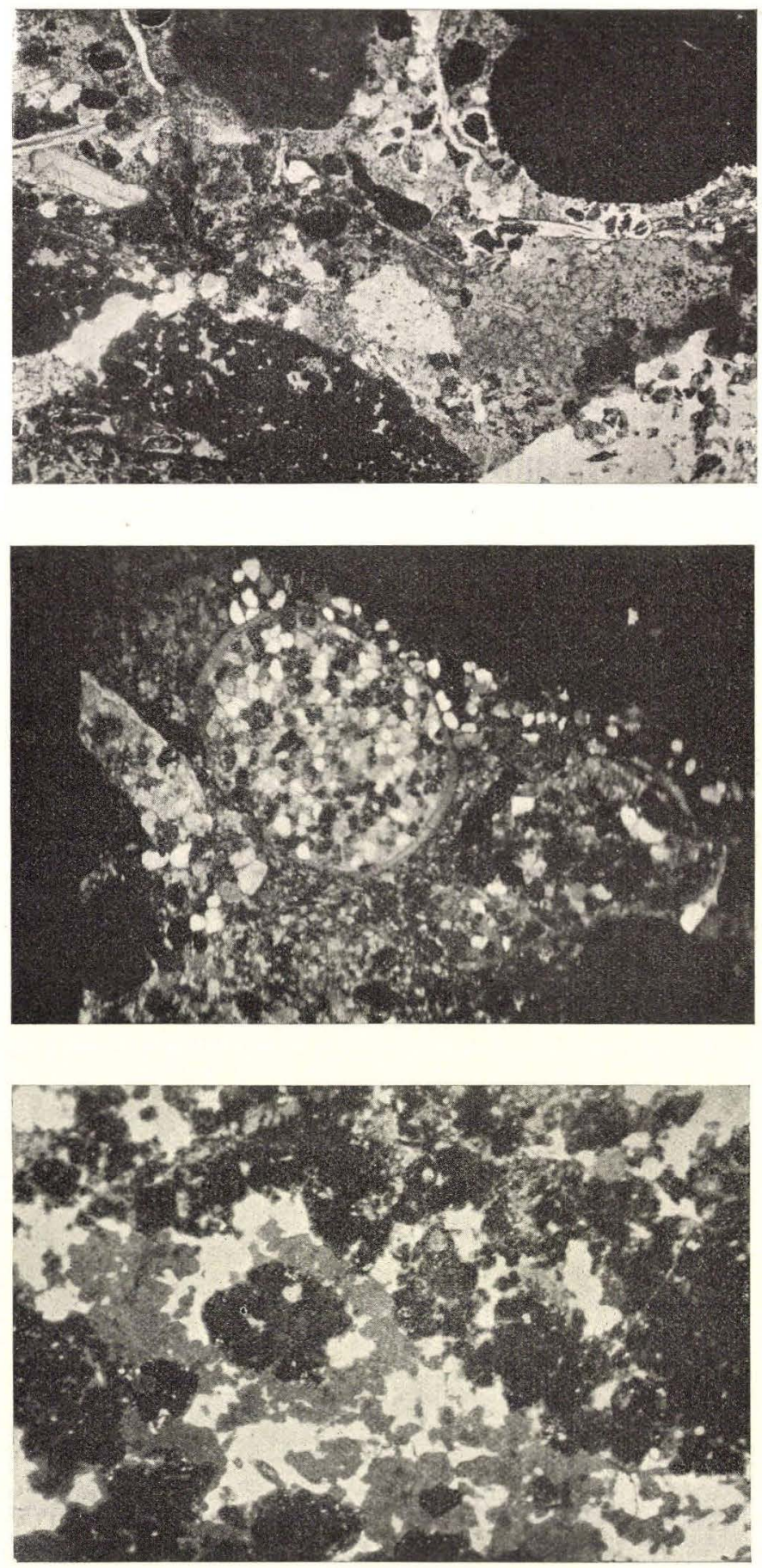
Fig. 1. Andrarum Limestone. Øleaa, Loc. 5. It consists of shell fragments in a ground-mass of fine calcareous mud.

Slide 672. Magn. $10 \times .1$ nicol.

Fig. 2. Stemmy stinkstone from the limestone bed of the Orusia Zone. Øleaa, Loc. 11.

Slide 722. Magn. ca. $15 \times$. Nicols + .

Fig. 3. Same slide as Fig. 2, but somewhat lower down. The crystals here are shorter but still have a rounded base and are pointed at the other end. 
Plate III.
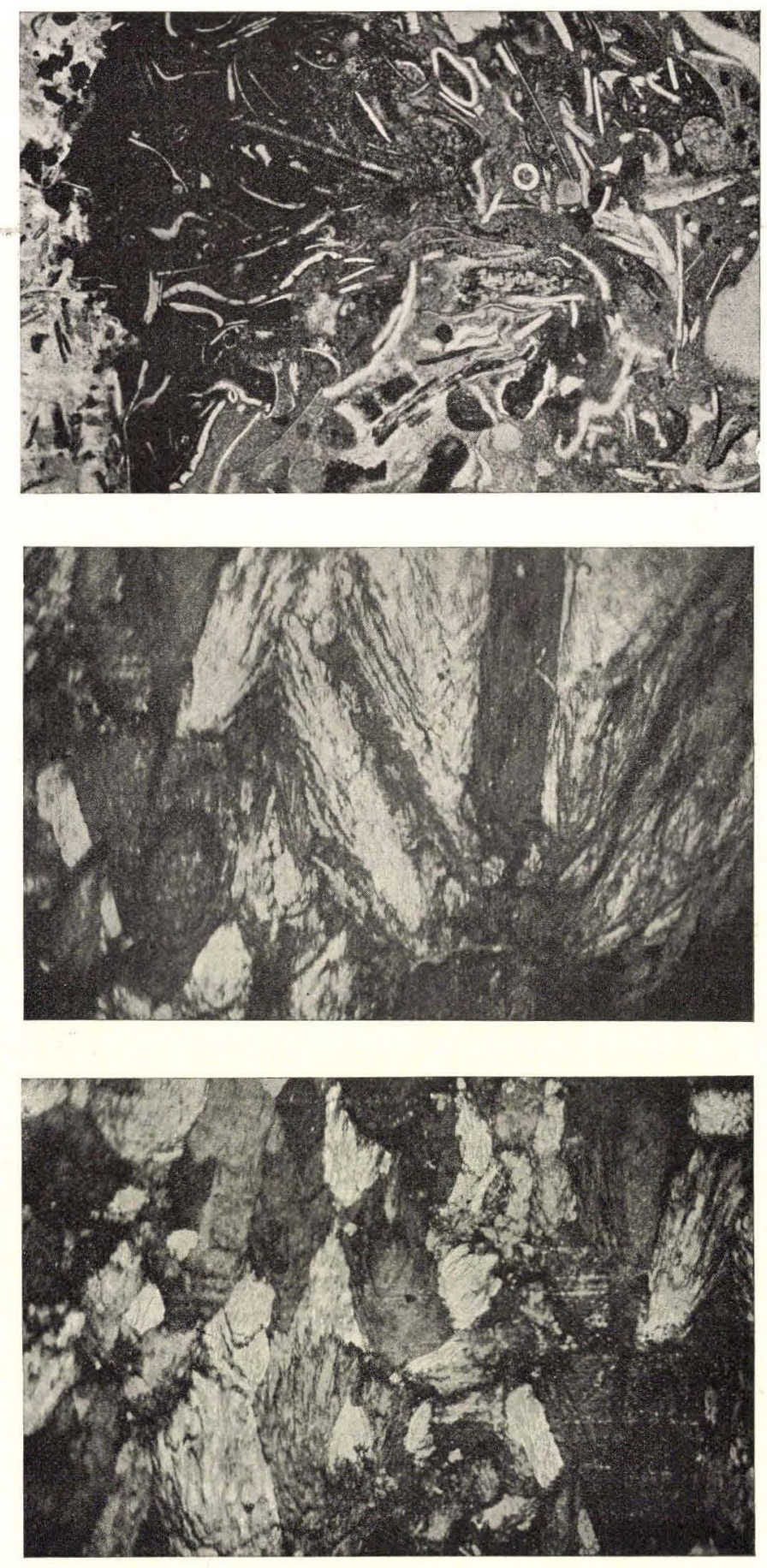
Fig. 1. Cross section of stemmy stinkstone from the Olenus Zone at the Øleaa, Loc. 8. Observe the often irregular cross section of the individual crystals and the numerous thin bands of black mud which intersperse the various crystals.

Slide 717. $25 \times$. Nicols + .

Fig. 2. Bushy calcite crystals along the edge of a shell fragment (the light streak in the middle). Andrarum Limestone. Øleaa, Loc. 5.

Slide 844 . ca. $40 \times .1$ nicol.

Fig. 3. Granophyric accretion between barites (the white) and calcite (the grey). All the white in the picture belongs to the same crystal individual.

The transitional stratum between the Davidis and Forchhammeri Zones. Læsaa, Loc. II. Slide 683. $55 \times$. Nicols + . 


\section{Plate IV.}
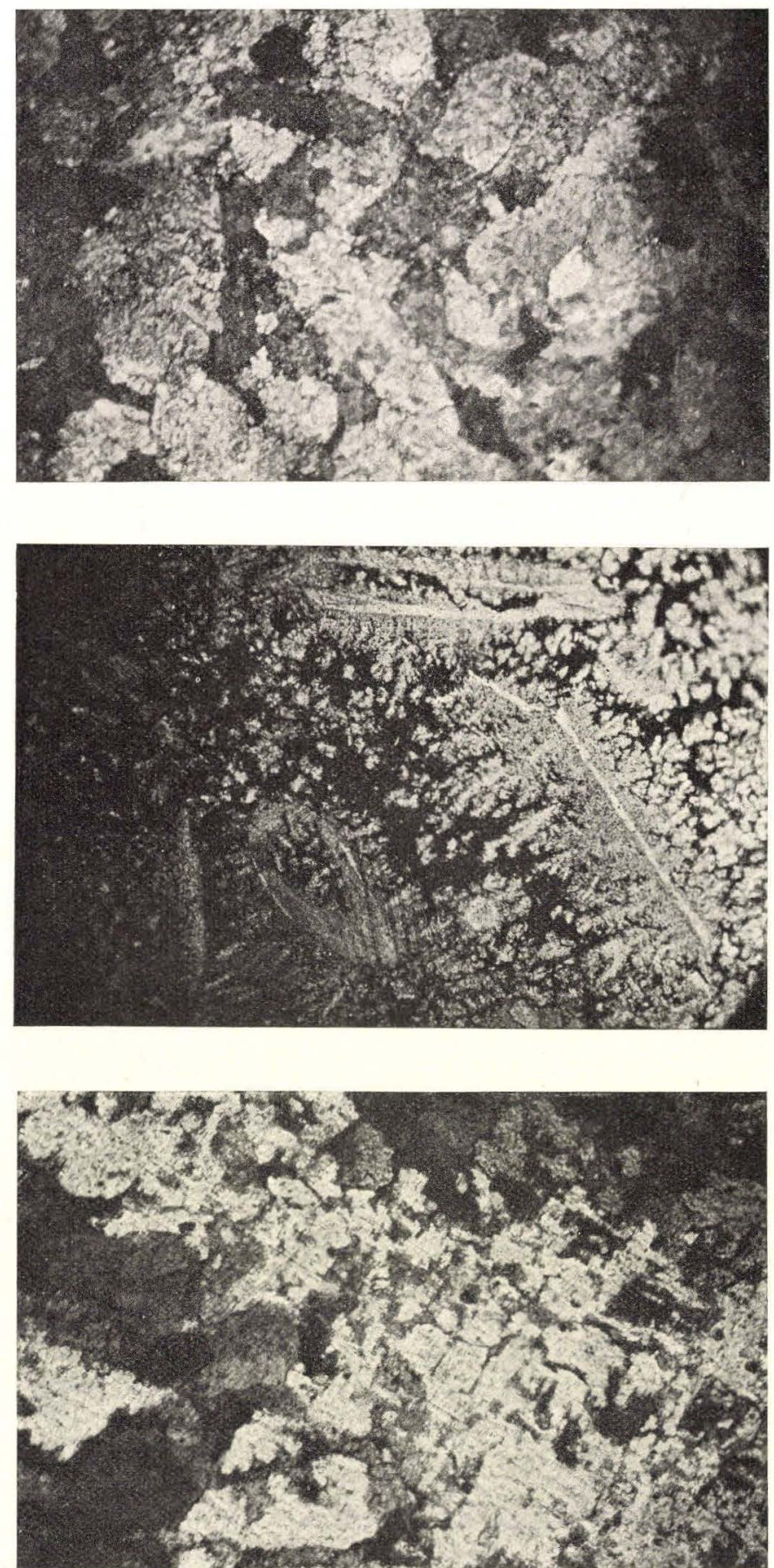
